$12-1-2021$

\title{
Stakeholder Syndrome: Does Stakeholderism Derail Effective Protections for Weaker Constituencies?
}

Matteo Gatti

Chrystin Ondersma

Follow this and additional works at: https://scholarship.law.unc.edu/nclr

Part of the Law Commons

\section{Recommended Citation}

Matteo Gatti \& Chrystin Ondersma, Stakeholder Syndrome: Does Stakeholderism Derail Effective Protections for Weaker Constituencies?, 100 N.C. L. REv. 167 (2021).

Available at: https://scholarship.law.unc.edu/nclr/vol100/iss1/4

This Article is brought to you for free and open access by Carolina Law Scholarship Repository. It has been accepted for inclusion in North Carolina Law Review by an authorized editor of Carolina Law Scholarship Repository. For more information, please contact law_repository@unc.edu. 


\title{
STAKEHOLDER SYNDROME: DOES STAKEHOLDERISM DERAIL EFFECTIVE PROTECTIONS FOR WEAKER CONSTITUENCIES?"
}

\author{
MATTEO GATTI" ${ }^{* *} \&$ CHRYSTIN ONDERSMA ${ }^{* * *}$
}

We evaluate stakeholderism in the context of one constituency-workers-by exploring a few key known contributors to workers' economic disadvantage: concentration and monopsony in labor markets, weak collective action protections for workers, a declining minimum wage, and the harsh realities of outsourced and gig work. After reviewing specific policy proposals in those areas, which we believe have the capacity to shift power and resources to workers, we then evaluate whether stakeholderism can help workers by offering a feasible substitute to these policies or by providing a fertile landscape for worker advancement. Available evidence suggests that corporations will seek to undermine any proposal that meaningfully shifts power and resources to workers. Consequently, stakeholderism is unlikely to provide equivalent protections that would actually improve the position of workers. Assuming stakeholderism could provide such protections, its implementation would be no more feasible than direct regulation. Stakeholderism can hardly provide a fertile landscape for direct regulation, because corporations would likely use it as a pretext to exert greater political power and shape the debate in their own favor, thus interfering with direct regulation. Ultimately, given the risks of allowing managers and directors to wield stakeholderism in their own interests, political capital should be spent on achieving direct regulation rather than on stakeholderist corporate governance reform.

INTRODUCTION

I. THE DEBATE ON STAKEHOLDERISM

II. SELECTED POLICIES OUTSIDE OF CORPORATE LAW AND

GOVERNANCE.

A. What Hurts Workers: Some Evidence ................................ 179

1. Firm Concentration and Labor Monopsony ............... 179

* (C) 2021 Matteo Gatti \& Chrystin Ondersma.

** Professor of Law, Rutgers Law School.

*** Professor of Law and Judge Morris Stern Scholar, Rutgers Law School.

For helpful comments and suggestions, we are grateful to Matt Bodie, Doug Eakeley, Alan Hyde, Aneil Kovvali, David Lopez, Amelia Miazad, Elizabeth Pollman, Jim Pope, Leo Strine, Roberto Tallarita, and participants in the Faculty Colloquium at Rutgers Law School on September 30, 2020, and in the National Business Law Scholars Conference on June 18, 2021. Thanks to Kevin Lenihan, Shradhha Patel and Hannah Reilly for their research efforts. All errors and omissions are our own. 
2. Weakening of Labor Market Institutions and Worker

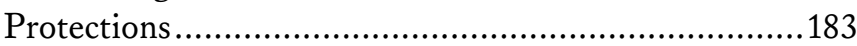

3. The Declining Minimum Wage .................................188

4. Outsourcing and Gig Work ....................................190

B. Policy Proposals.............................................................. 191

1. Addressing Concentration and Monopsony Power...... 191

2. Strengthening Worker Collective Action....................196

3. Increasing the Minimum Wage................................ 203

4. Empowering Outsourced Labor and Gig Workers ......207

III. STAKEHOLDERISM VS. DIRECT REGULATION ...................... 209

A. How Corporations Deal with Requests from the Workforce...... 209

1. The Opacities of Corporate Lobbying .........................210

2. Corporate Efforts To Thwart Worker Rights and

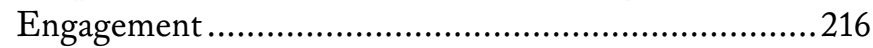

a. Preventing Unionization .........................................216

b. Preventing Workers from Enforcing Their Rights via Mandatory Arbitration Clauses ..............................219

c. Thwarting the Rights of Gig Workers ........................221

B. The Dubious Advantages of Stakeholderism .........................222

1. A Feasible Substitute for Direct Regulation? ..............222

2. A Better Environment To Advance Workers'

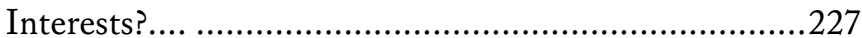

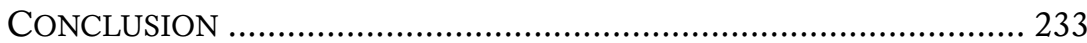

\section{INTRODUCTION}

Broadening the corporate purpose to embrace stakeholderism is a hot topic in corporate law and governance these days. Stakeholder theory predicates a shift from the shareholder primacy norm ${ }^{1}$ to an alternative approach under which directors should be charged with (and held responsible for) creating value for all constituencies of the corporation, including employees, customers,

1. The shareholder primacy norm predicates that the main duty of corporate directors is to maximize wealth for shareholders. See, e.g., D. Gordon Smith, The Shareholder Primacy Norm, 23 J. CORP. L. 277, 278 (1998) ("Corporate directors have a fiduciary duty to make decisions that are in the best interests of the shareholders. This aspect of fiduciary duty is often called the shareholder primacy norm."). 
suppliers, and local communities. ${ }^{2}$ Recently, major political and business actors ${ }^{3}$ joined a group of corporate scholars ${ }^{4}$ in blaming shareholder primacy for the plight of weaker constituencies (such as workers and consumers). Supporters of stakeholderism see it as crucial to shift power and resources to these constituencies. In a previous paper, we showed that shareholder primacy is not a key contributor to rampant economic inequality ${ }^{5}$ or the weakening of nonshareholder constituencies. ${ }^{6}$ Rather, several other factors including concentration and market power, declining protections from labor market institutions, dismantling of the social safety net, deregulation, and declining

2. See generally Margaret M. Blair \& Lynn A. Stout, $A$ Team Production Theory of Corporate Law, 85 VA. L. REV. 247 (1999) (proposing a shift away from the shareholder primacy norm); CoLIN MAYER, PROSPERITY: BETTER BusINESS MAKES GREATER GOOD (2018) [hereinafter MAYER, PROSPERITY] (proposing a new agenda for establishing the corporation as a force for societal prosperity); COLIN MAYER, FIRM COMMITMENT: WHY THE CORPORATION IS FAILING US AND HOW TO RESTORE TRUST IN IT (2013) [hereinafter MAYER, FIRM COMMITMENT] (arguing that the corporate structure is flawed and proposing several alternatives).

3. Recent sponsors of the stakeholder approach could not be any more different. On the one hand, prominent progressives such as Senators Elizabeth Warren and Bernie Sanders embraced the stakeholder approach in corporate law reform proposals they put forth while they were vying for the Democratic nomination in the 2020 presidential election. See Accountable Capitalism Act, S. 3348, 115th Cong. $\S 5$ (2018); Corporate Accountability and Democracy Plan, BERNIE, https://berniesanders. com/issues/corporate-accountability-and-democracy/ [https://perma.cc/EF45-BPGV]. On the other hand-and, to some extent, surprisingly-Wall Street titans such as the CEOs of BlackRock and the Business Roundtable ("BRT") (the lobbying group comprised of CEOs of large American corporations) made waves with their departure from the shareholder maximization norm, which up to that point was considered the gold standard in American capitalism. See Larry Fink, 2018 Letter to CEOs: A Sense of Purpose, BLACKROCK (2018), https://www.blackrock.com/corporate/investorrelations/2018-larry-fink-ceo-letter [https://perma.cc/3YYU-MAEL]; Statement on the Purpose of a Corporation, BUS. ROUNDTABLE (Aug. 19, 2019), https://www.businessroundtable.org/businessroundtable-redefines-the-purpose-of-a-corporation-to-promote-an-economy-that-serves-all-americans [https://perma.cc/9N SR-P859] [hereinafter Corporation Purpose Statement].

4. See David Millon, Communitarianism in Corporate Law: Foundations and Law Reform Strategies, in Progressive Corporate LAW 1, 3 (Lawrence E. Mitchell ed., 1995); David Millon, Communitarians, Contractarians, and the Crisis in Corporate Law, 50 WASH. \& LEE L. REV. 1373, 1376 (1993); KENT GREENFIELD, THE FAILURE OF CORPORATE LAW: FUnDAMENTAL FlaWS AND PROGRESSIVE POSSIBILITIES 1-2 (2006). For an assessment of progressive corporate law, see Matthew T. Bodie, The Next Iteration of Progressive Corporate Law, 74 WASH. \& LEE L. REV. 739, 74041 (2017).

5. For an account of the rise over the last decades of inequality in income distribution in the United States, see Thomas Piketty, Emanuel Saez \& Gabriel Zucman, Distributional National Accounts: Methods and Estimates for the United States, 133 Q.J. ECON. 553, 557 (2018) (showing the losses suffered by the lower tail of income distribution).

6. To be sure, Anna Stansbury and Larry Summers recently argued that the shareholder primacy norm in fact is one of the factors that contributed to worker disempowerment. See Anna Stansbury \& Lawrence H. Summers, The Declining Worker Power Hypothesis: An Explanation for the Recent Evolution of the American Economy 9 (Nat'l Bureau of Econ. Rsch., Working Paper No. 27193, 2020), https://www.nber.org/papers/w27193 [https://perma.cc/JK7A-3SRQ]. For an assessment of this argument, see infra note 54 . 
progressive taxation are larger drivers. $^{7}$ In addition, we criticized stakeholderism - a term which we use in our earlier work and throughout this Article primarily to describe a corporate law reform expanding director duties $^{8}$-for its inability to effectively protect weaker constituencies ${ }^{9}$ and warned that its adoption would not be painless. ${ }^{10} \mathrm{We}$ raised concerns over the fact that stakeholderism could be used as both a shield and a sword: corporations could use it to defend the status quo and interfere with opportunities to achieve reforms that would shift power and resources to weaker constituencies via direct regulation. ${ }^{11}$ Since then, there have been renewed defenses of stakeholderism, many of which take the view that direct regulation is not feasible in the current environment and that stakeholderism will successfully lead to incremental change as well as create an environment more conducive to passage of direct regulation. ${ }^{12}$

In this Article, we evaluate stakeholderism in the context of one constituency-workers-by exploring a few key known contributors to workers' economic disadvantage: concentration and monopsony in labor markets, weak collective action protections for workers (together with a diminished enforceability of employment rights), a declining minimum wage, and the harsh realities of outsourcing and gig work. We identify policy proposals in these areas, which we believe can shift power and resources to workers, and then evaluate whether stakeholderist proposals can help workers in any way-either by offering substitutes to regulatory policies or by providing a fertile landscape for worker advancement. We provide evidence suggesting that corporations will seek to undermine any proposal that meaningfully shifts power and resources to workers, and we therefore argue that any stakeholder proposal with the

7. Matteo Gatti \& Chrystin Ondersma, Can a Broader Corporate Purpose Redress Inequality? The Stakeholder Approach Chimera, 46 J. CORP. L. 1, 10-11, 47-57 (2020).

8. Our critique of stakeholderism is circumscribed to the proposed shift in fiduciary duties. It does not mean we oppose any corporate law and governance changes: here, we simply do not take a position on such other changes. Cf. infra note 375 and accompanying text. Similarly, this Article does not imply that we do not welcome cultural changes in the C-suite aimed at "growing the pie" in ways that favor a broader range of constituencies. See generally ALEX EDMANS, GROW THE PIE: CREATING PROFIT FOR INVESTORS AND VALUE FOR SOCIETY (2020) (arguing that companies can simultaneously create both profit and social value). Yet, for the reasons highlighted throughout this Article, we do not believe any such cultural movement alone could fix the ails of American capitalism without bold structural policy interventions. See infra notes 55, 322-28 and accompanying text.

9. Gatti \& Ondersma, supra note 7, at 60-63.

10. See id. at 63-69.

11. First, managers and directors can play offense by expanding lobbying efforts, purportedly in the interest of all stakeholders, thus risking corporate capture of the reformist agenda. Id. at 64-67. Second, corporations can deploy stakeholderism defensively by arguing that no direct regulation is needed. Id. at 67-69.

12. See, e.g., Leo E. Strine, Jr., Restoration: The Role Stakeholder Governance Must Play in Recreating a Fair and Sustainable American Economy: A Reply to Professor Rock, 76 BUS. LAW. 397, 399-400 (2021) [hereinafter Strine, Restoration]. 
potential to actually improve workers' position is no more feasible than direct regulation. Nor do we believe that stakeholderism can provide a fertile landscape for direct regulation because corporations are likely to use stakeholderist corporate governance changes to wield greater political power and to shape the debate in their own favor, thus interfering with direct regulation. We therefore urge policymakers to prioritize tools such as antitrust protections, broad collective bargaining, a higher federal minimum wage, and a reclassification of outsourced and gig labor, which are more effective in directly helping weaker constituencies.

While this Article acknowledges the need for greater collaboration across fields and disciplines, which we called for in our earlier work, ${ }^{13}$ it also breaks new ground in corporate law by venturing into interdisciplinary territory and assessing the merits of policy proposals in the antitrust and labor fields. Indeed, there are important benefits in exploring initiatives in such fields in the context of the ongoing debate on stakeholder capitalism and from the vantage point of a corporate lawyer. First, doing so allows us to reposition the conversation to focus on why directors should be the ones supporting weaker constituencies and how directors should operate. Otherwise, the exercise of broadening the board's freedom to operate without looking into such interrogatives would become empty, if not dangerous. It would be empty because we would be expanding the powers of an already powerful corporate body with no indication as to how such powers should be used. In other words, we would stop short of making any meaningful change other than a symbolic switch resulting in broader director authority. It could also be dangerous because corporations may use stakeholderism as an excuse to exert even greater power over the political discourse, potentially impeding the reforms most likely to shift power and resources to workers.

Second, exploring policy discussions in other fields with a corporate law lens offers a litmus test on what to expect from corporations if they ever embrace stakeholderism. Will stakeholderism contribute to a more collaborative stance toward unions and collective bargaining? Will stakeholderism call for increasing the minimum wage? Will it result in any significant change in the ways corporations routinely outsource tasks that are traditionally carried out by employees? Will it pause the impetus of firm concentration? Crucially, can any of the foregoing issues be worked out solely thanks to broadened corporate purpose without any legislative or regulatory involvement, as proponents such as Martin Lipton have suggested? ${ }^{14}$

13. See Gatti \& Ondersma, supra note 7 , at 72 (noting that "the whole discussion on stakeholderism suffers from compartmentalization a great deal").

14. Martin Lipton, Corporate Governance: The New Paradigm, HARV. L. SCH. F. ON CORP. GOVERNANCE (Jan. 11, 2017), https://corpgov.law.harvard.edu/2017/01/11/corporate-governance-thenew-paradigm/\#1 [https://perma.cc/D686-D7GK] [hereinafter Lipton, Corporate Governance]. 
A corporation that embraces stakeholderism, and thus purports to be concerned about weaker constituencies, should indeed be expected to favor (or at least not thwart) unions, an increased minimum wage, and so forth. In other words, a stakeholderist movement that is serious about caring for its employees should bring less friction in industrial relations and a more welcoming stance on unions and other labor market institutions protecting workers. If stakeholderism could offer these results, it would be much less objectionablein fact, embracing it could lead to success. However, there is little indication that this is happening or that real-world stakeholderism is moving in this direction. ${ }^{15}$

This Article proceeds as follows. In Part I we very briefly review stakeholderism, focusing on new contributions from advocates and skeptics (including our own). We take particular note of the claims that stakeholderism is more feasible than direct regulation and is essentially a prerequisite for meaningful regulation. In Part II we explore regulatory areas of reform in which empirical evidence suggests regulation can in fact shift power and resources to workers. Namely, we address concentration in labor markets, promoting collective action among workers, increasing the minimum wage, and tackling abuses in labor outsourcing and in the treatment of gig workers. We note that, while antitrust initiatives strive to avoid further weakening of workers as a result of concentration, each reform on the labor front has the capacity to shift power and resources to workers-in other words, these measures work from the bottom up. The purpose of surveying such proposals is to put them in contrast with the stakeholderist claim that would instead privilege a top-down change from within and at the top of corporate power-the boardroom. In Part III we consider whether stakeholderism can assist in achieving such reforms or whether instead it might be a hindrance. We first review the behavior of corporations as it relates to workers, and show that, in addition to lobbying (often opaquely) to retain and expand their share of influence to avoid liability, corporations persistently thwart efforts to increase workers' power and resources, including by preventing unionization, requiring employees to arbitrate, and refusing to extend benefits and protections to gig workers and

15. See generally Aneesh Raghunandan \& Shiva Rajgopal, Do Socially Responsible Firms Walk the Talk? (Apr. 1, 2021) (unpublished manuscript), https://papers.ssrn.com/sol3/papers.cfm?abstract _id=3609056 [https://perma.cc/YX7Q-JV4L] (noting that signatories to the BRT Statement have had, both before and after the Statement, a worse track record than their within-industry peers on issues such as the environment, labor compliance, lobbying efforts, receipt of governmental subsidies, and responsiveness to shareholder proposals); Lucian A. Bebchuk \& Roberto Tallarita, Will Corporations Deliver Value to All Stakeholders?, 75 VAND. L. REV. (forthcoming May 2022) [hereinafter Bebchuk \& Tallarita, Will Corporations Deliver Value], https://papers.ssrn.com/sol3/papers.cfm?abstract_id= 3899421 [https://perma.cc/7NL9-ZSKX] (reviewing corporate documents of over 130 U.S. public companies that joined the BRT Statement and finding no material changes in how such companies treat their stakeholders in the wake of the BRT Statement). 
other outsourced labor whom they control. In evaluating whether stakeholderism can advance the interests of workers, we argue that an effective proposal must be mandatory, enforceable, and specific, and we note stakeholderism does not have these characteristics. We then ask if, despite lacking these qualities, a stakeholder approach may create a fertile landscape for worker advancement, including for direct regulation. We posit that stakeholderist corporate governance changes have little role to play in shifting the cultural landscape in favor of regulation. In fact, when corporations cede power to workers, it is in response to public pressure (for example, the \#MeToo movement). ${ }^{16} \mathrm{We}$ also make note of the risk that corporations will simply coopt a stakeholderist agenda, just as they have co-opted progressive agendassuch as arbitration and, to some extent, antitrust -in the past.

Our analysis supports the conclusion that time, resources, and political capital are not put to their highest and best use when directed at stakeholderist corporate governance proposals. Instead, proposals for direct regulation that will protect workers (such as broadening unions' reach and minimizing labor monopsony, to name a couple) are more worthy of consideration. We fear that, rather than pave the way for these proposals, stakeholderism will instead create bumps, if not roadblocks. All in all, outsourcing the protection of weaker constituencies to directors and managers, the core of the very power structure that has constantly been vexing worker prerogatives, seems not only disingenuous but also dangerous.

\section{THE DEBATE ON STAKEHOLDERISM}

Ever since the early 1900s, scholars, courts, and policymakers have been debating the purpose of the corporation-namely, whether it is merely to maximize shareholder wealth or whether it must also serve workers, communities, creditors, consumers, and the environment. In the United States, this debate started with the famous Dodge v. Ford Motor Company ${ }^{17}$ case in 1919 and continued with the Berle-Dodd exchange of the early 1930s. ${ }^{18}$ In the 1970s, Milton Friedman published a famous article in New York Times Magazine in which he dismissed stakeholder theories on the argument that a corporate executive is always spending "someone else's money" and should not be permitted to pursue any end other than maximizing the value of the

16. See infra notes $352-60$ and accompanying text.

17. 170 N.W. 668, 684 (Mich. 1919) (holding that the purpose of a corporation is to produce profits for shareholders but adding that a judge will not second-guess decisions stemming from the business judgment of directors). For a critique that this affirms shareholder primacy, see LYNN STOUT, THE SHAREHOLDER VALUE MYTH 31 (2012).

18. Compare Adolph A. Berle, Jr., Corporate Powers as Powers in Trust, 44 HARV. L. REV. 1049, 1049 (1931) (arguing that corporate powers are held in trust for shareholders), with E. Merrick Dodd, Jr., For Whom Are Corporate Managers Trustees?, 45 HARV. L. REV. 1145, 1148 (1932) (arguing that the corporation is "an economic institution which has a social service as well as a profit-making function"). 
corporation. ${ }^{19}$ The debate resurfaced in the 1980s when that decade's hostile takeover boom prompted companies to adopt defenses with the declared goal of protecting, among others, weaker constituencies and to lobby state legislatures to pass various antitakeover legislation, including constituency statutes that would expressly allow directors to protect a broader set of stakeholders. ${ }^{20}$ Recent debate has been heavily influenced by a seminal article by Margaret Blair and Lynn Stout, in which the authors propose a view of the corporation as a joint project comprised of varied members who enter into an agreement to work together for mutually beneficial value, and argue that corporate purpose cannot be to maximize wealth just for shareholders, but also for employees, customers, suppliers, and other stakeholders. ${ }^{21}$ In the early 2000s, the consensus was that shareholder-value proponents had triumphed over alternative views on corporate purpose; that is, the predominant view was:

[U]ltimate control over the corporation should rest with the shareholder class; the managers of the corporation should be charged with the obligation to manage the corporation in the interests of the shareholders; other corporate constituencies, such as creditors, employees, suppliers, and customers, should have their interests protected by contractual and regulatory means rather than through participation in corporate governance. $^{22}$

Despite shareholder maximization becoming the dominant view, a minority of scholars have continued to advocate for a stakeholder approach. ${ }^{23}$ Under this view, managers and directors can and should cater to the interests of, and maximize the value allocated to, employees, creditors, customers, suppliers, local communities, the environment, and society as a whole. ${ }^{24}$

19. Milton Friedman, The Social Responsibility of Business Is To Increase Its Profits, N.Y. TimES MAG., Sept. 13, 1970, at 32, 33. For a contextualization of Friedman's article at its fiftyyear anniversary, see Luca Enriques, Missing in Today's Shareholder Value Maximization Credo: The Shareholders, PROMARKET (Sept. 22, 2020), https://promarket.org/2020/09/22/milton-friedmanvalue-maximization-credo-is-missing-the-shareholders/ [https://perma.cc/C4XB-F5YQ] (arguing that Friedman's main point was less about the maximization of profits than the undesirability of pursuing social goals using shareholders' money).

20. One of the principal advocates for this approach was Martin Lipton. See, e.g., Martin Lipton, Takeover Bids in the Target's Boardroom, 35 BUS. LAW. 101, 104 (1979); Martin Lipton, Corporate Governance in the Age of Finance Corporatism, 136 U. PA. L. REV. 1, 59-69 (1987).

21. See Blair \& Stout, supra note 2, at 278.

22. Henry Hansmann \& Reinier Kraakman, The End of History for Corporate Law, 89 GEO. L.J. 439, 440-41 (2001). As Dorothy Lund and Elizabeth Pollman explain, there were far more factors at work in this shift in corporate purpose than merely corporate law; instead, "a vast array of institutional players-proxy advisors, stock exchanges, ratings agencies, institutional investors and associationsenshrine shareholder primacy in public markets." Dorothy S. Lund \& Elizabeth Pollman, The Corporate Governance Machine, 121 COLUM. L. REV. (forthcoming 2021) (manuscript at 1), https://ssrn.com/ abstract $=3775846$ [https://perma.cc/74TU-MF4Z].

23. See Blair \& Stout, supra note 2, at 250-51.

24. See id.; see also supra note 4 and accompanying text. 
Stakeholder theorists argue that "the corporation consists of all stakeholders who are responsible for the business of the enterprise," ${ }^{25}$ and that, therefore, directors' fiduciary duties run to the corporation as a whole. ${ }^{26}$ These scholars maintain that directors serve as "mediating hierarchs" capable of managing relationships among varied constituents. ${ }^{27}$

Recently, the stakeholder approach was endorsed by powerful business leaders. Indeed, in a now famous letter released in early 2018, Larry Fink, CEO of BlackRock (the largest of the big three "passive" asset managers) singlehandedly revived the debate on corporate purpose: according to Fink, "[c]ompanies must benefit all of their stakeholders, including shareholders, employees, customers, and the communities in which they operate." ${ }^{28}$ A little over a year and a half later, corporations took the center stage to voice their views on the issue via their powerful lobbying organization, the Business Roundtable ("BRT"). ${ }^{29}$ In August 2019, the BRT disclaimed shareholder primacy and embraced a broader stakeholder approach. ${ }^{30}$ In its "Statement on the Purpose of a Corporation," signed by a group including the CEOs of Amazon, Apple, Bank of America, GM, IBM, and JPMorgan Chase, the BRT announced that the creation of shareholder value was no longer the principal purpose of corporations. ${ }^{31}$ Instead, drawing from Colin Mayer and Martin Lipton, ${ }^{32}$ the BRT affirmed that "each of [its] stakeholders is essential," including employees, suppliers, and customers, and agreed to "deliver value to all of them, for the future success of our companies, our communities and our country." ${ }^{3}$

25. Grant Hayden \& Matthew T. Bodie, Shareholder Democracy and the Curious Turn Toward Board Primacy, 51 WM. \& MARY L. REv. 2071, 2091 (2010).

26. Id.

27. Blair \& Stout, supra note 2, at 280.

28. Fink, supra note 3.

29. Corporation Purpose Statement, supra note 3.

30. Id.

31. Id.

32. For Mayer, see MAYER, PROSPERITY, supra note 2, and MAYER, FIRM COMMITMENT, supra note 2. For Lipton, see Lipton, Corporate Governance, supra note 14 ("[C]orporations and investors should band together to resist legislation and regulation that may discourage long-term investment or that presumes that the long-term health of society is not aligned with the long-term interests of business.")

33. Corporation Purpose Statement, supra note 3; see Randi V. Morrison, BRT Statement of Corporate Purpose: Debate Continues, HARV. L. SCH. F. ON CORP. GOVERnANCE (Aug. 28, 2020), https://corpgov.law.harvard.edu/2020/08/28/brt-statement-of-corporate-purpose-debatecontinues/ [https://perma.cc/J8YL-TQGH] (clarifying that "companies need to generate 'long-term value for shareholders," and that the Statement "pragmatically reflects... the reality that for corporations to be successful, durable and return value to shareholders, they need to consider the interests and meet the fair expectations of a wide range of stakeholders in addition to shareholders, including customers, employees and the communities in which they operate"). 
The BRT Statement generated a wave of diverse reactions. On the one hand, some commentators welcomed it enthusiastically ${ }^{34}$ and some others expressed cautious optimism. ${ }^{35}$ On the other hand, many others raised concerns ${ }^{36}$ or dismissed the Statement and denounced its rhetoric as empty ${ }^{37}$ or old.$^{38}$ Criticism of the BRT stems from support of shareholder value ${ }^{39}$ and a

34. See Martin Lipton, Wachtell Lipton Discusses Stakeholder Corporate Governance: Business Roundtable and CII, CLS BLUE SKY BLOG (Aug. 26, 2019), https://clsbluesky.law.columbia. edu/2019/08/26/wachtell-lipton-discusses-stakeholder-corporate-governance-business-roundtable-and -cii/ [https://perma.cc/4KNL-JGGW] (endorsing the BRT's Statement and dubbing as misguided the rejection of the Statement by the Council of Institutional Investors); Michael Spence, The End of Shareholder Primacy?, PROJECT SYNDICATE (Aug. 26, 2019), https://www. project-syndicate.org/commentary/shareholder-vs-multi-stakeholder-model-by-michael-spence-201908?barrier=accesspaylog [https://perma.cc/865N-X82M].

35. See Andrew Ross Sorkin, How Shareholder Democracy Failed the People, N.Y. TIMES DEALBOOK (Aug. 21, 2019), https://www.nytimes.com/2019/08/20/business/dealbook/businessroundtable-corporate-responsibility.html [https://perma.cc/C8JD-GKWT].

36. See Press Release, Council of Institutional Invs., Council of Institutional Investors Responds to Business Roundtable Statement on Corporate Purpose (Aug. 19, 2019), https://www.cii.org/aug19 brt_response [https://perma.cc/5KWY-RPTD]; Luigi Zingales, Opinion, Don't Trust CEOs Who Say They Don't Care About Shareholder Value Anymore, WASH. POST (Aug. 20, 2019, 6:54 PM), https://www.washingtonpost.com/opinions/2019/08/20/dont-trust-ceos-who-say-they-dont-care-

about-shareholder-value-anymore/ [https://perma.cc/8GFE-889F (dark archive)]; see also Jeffrey N. Gordon, Addressing Economic Insecurity: Why Social Insurance Is Better than Corporate Governance Reform, CLS BLUE SKY BLOG (Aug. 21, 2019), https://clsbluesky.law.columbia.edu/2019/08/21/addressingeconomic-insecurity-why-social-insurance-is-better-than-corporate-governance-reform [https://perma .cc/QM5E-UW88]; Lawrence H. Summers, Opinion, If Business Roundtable CEOs Are Serious About Reform, Here's What They Should Do, WASH. POST (Sept. 2, 2019, 5:57 PM), https://www. washingtonpost.com/opinions/if-business-roundtable-ceos-are-serious-about-reform-heres-what-theyshould-do/2019/09/02/53b05014-cdc0-11e9-8c1c-7c8ee785b855_story.html [https://perma.cc/JEH5-8 HMQ (dark archive)] (worrying, among other things, about issues such as executive accountability and enforcement of the principles laid out by the BRT); Mark J. Roe, Why Are America's CEOs Talking About Stakeholder Capitalism Now?, OXFORD BUS. L. BLOG (Nov. 4, 2019), https://www.law.ox.ac. uk/business-law-blog/blog/2019/11/why-are-americas-ceos-talking-about-stakeholder-capitalism-now [https://perma.cc/N85Y-HTLK] [hereinafter Roe, America's CEOs].

37. See Jesse Fried, The Roundtable's Stakeholderism Rhetoric Is Empty, Thankfully, HARV. L. SCH. F. ON CORP. GOVERNANCE (Nov. 22, 2019), https://corpgov.law.harvard.edu/2019/11/22/theroundtables-stakeholderism-rhetoric-is-empty-thankfully/ [https://perma.cc/EM97-BJH3] (arguing that the BRT's proposal would not change much from a positive law standpoint, because CEOs and directors are bound by shareholder primacy by virtue of previous contractual arrangements that give shareholders appointment and removal rights).

38. See Luca Enriques, The Business Roundtable CEOs' Statement: Same Old, Same Old, PROMARKET (Sept. 9, 2019), https://promarket.org/the-business-roundtable-ceos-statement-sameold-same-old/ [https://perma.cc/LW3W-A7MM] [hereinafter Enriques, Same Old] (noting that some of the BRT's commitments were already present in the 2016 Principles of Corporate Governance and that there are no ways for stakeholders to enforce the promises the BRT makes); see also Katharina Pistor, Why America's CEOs Have Turned Against Shareholders, PROJECT SYNDICATE (Aug. 26, 2019), https://www.project-syndicate.org/commentary/american-ceos-turn-against-shareholder-primacy-bykatharina-pistor-2019-08 [https://perma.cc/NK6S-UY8M] [hereinafter Pistor, Against Shareholders] (arguing that CEOs cannot pick and choose a corporation's purpose as they are not principals but mere agents and denouncing the futility of the Statement because of the lack of remedies for stakeholders).

39. See Edward B. Rock, For Whom Is the Corporation Managed in 2020?: The Debate Over Corporate Purpose, 76 BUS. LAW. 363, 370-78, 395 (2021) [hereinafter Rock, For Whom] ("The private lawyer's 
belief that managers and directors will use stakeholderism pretextually. ${ }^{40} \mathrm{We}$, in particular, have expressed the view that corporate governance is not to blame for the weak position of constituents like workers and consumers; to improve their positions, it is far more important to engage with other fields such as antitrust, labor, and tax. ${ }^{41}$ Additionally, we have argued that stakeholderism is risky because corporations can deploy it strategically to defend the status quo and thwart regulation capable of improving workers' positions. ${ }^{42}$

Meanwhile, important commentators have renewed the call for stakeholderism. ${ }^{43}$ Former Chief Justice of the Delaware Supreme Court Leo Strine lauded the approach as an achievable, incremental gain that would also create a fertile landscape for regulatory reform. ${ }^{44}$ His view promotes stakeholderism as an "evolutionary means" 45 of building on corporate law techniques, an approach capable of "restor[ing] the regulatory framework within which corporate power used to be exercised," 46 as well as "limit[ing] the extent to which corporations use their influence in order to prevent the political process from putting in place effective external regulations." ${ }^{37}$ In Strine's opinion, regulatory solutions such as taxation or worker- and consumerprotection regulations are not feasible in the absence of a stakeholder approach "because of the influence of corporate and business elites on our political

worry, of course, is that using private law to solve social problems will destroy the value generating potential of private law while failing to solve the social problems, leaving all of us worse off."); see also Lucian A. Bebchuk \& Roberto Tallarita, The Illusory Promise of Stakeholder Governance, 106 CORNELL L. REv. 91, 92 (2020) [hereinafter Bebchuk \& Tallarita, Illusory Promise]; Fried, supra note 37; Sean J. Griffith, Saving Capitalism (unpublished manuscript) (on file with author) (reviewing COLIN MAYER, PROSPERITY: BETTER BUSINESS MAKES GREATER GOOD (2018)).

40. See Bebchuk \& Tallarita, Illusory Promise, supra note 39, at 108; Gatti \& Ondersma, supra note 7 , at $9-10$.

41. Gatti \& Ondersma, supra note 7 , at $60-63,70-72$.

42. Id. at 68-69.

43. See, e.g., Strine, Restoration, supra note 12, at 399-400 (arguing that the restoration of stakeholderism will lead to better outcomes in the aggregate); Colin Mayer, Shareholderism Versus Stakeholderism - A Misconceived Contradiction. A Comment on "The Illusory Promise of Stakeholder Governance" by Lucian Bebchuk and Roberto Tallarita 9 (Euro. Corp. Governance Inst., Law Working Paper No. 522/2020, 2020) [hereinafter Mayer, Shareholderism Versus Stakeholderism], https://papers.ssrn.com/sol3/papers.cfm?abstract_id=3617847 [https://perma.cc/F5FE -NZFU] (arguing that the reinvigoration of stakeholderism generates business incentives which benefit society); Martin Petrin \& Barnali Choudhury, Corporate Purpose and Short-Termism, RSCH. HANDBOOK ON COMPAR. CORP. GOVERnANCE (Afra Afsharipour \& Martin Gelter eds.) (forthcoming 2020) (manuscript at 22), https://papers.ssrn.com/sol3/papers.cfm?abstract_id=3538156 [https://perma.cc/TCH2-KYS6] (arguing for the elevation of stakeholder interests to the level of shareholder interests).

44. See Strine, Restoration, supra note 12, at 399-400.

45. Id. at 401.

46. Id. at 401 .

47. Id. at 423 (noting that "in order to revitalize external regulation, advocates of a fairer society rationally became convinced that internal corporate governance reform was required"). 
process." ${ }^{48}$ The hope, then, is that stakeholderism will result in positive incremental change while also laying the groundwork for direct regulation. ${ }^{49}$ Colin Mayer also defended stakeholderism, arguing that "[o]nce we appreciate that trade-offs and judgments are inherent in any system then we should start to think about what trade-offs and judgments we want business to make." ${ }^{50}$ Noting that regulation would impose high costs on corporations and that they would lobby against it and seek to circumvent it, he believes corporate purpose is the proper starting place for serving weaker constituencies. ${ }^{51} \mathrm{He}$ suggests that, contrary to an "enlightened shareholderist" approach (under which corporations consider other stakeholders but still focus on wealth maximization), a stakeholderist statement of corporate purpose would make accountability of management "laser sharp." $52 \mathrm{He}$ concludes that "we need a multiplicity of purposes and corporate forms to address the multitude of problems that have been of our own creation." ${ }^{53}$

\section{SELECTED POLICIES OUTSIDE OF CORPORATE LAW AND GOVERNANCE}

While some deploy stakeholderism only strategically, there are other proponents who view it as the main conduit to the protection of weaker constituencies. One would assume that an essential component of evaluating a broadened corporate purpose should be to carefully establish whether it is in fact capable of shifting power and resources to such constituencies. To identify which interventions are likely to serve their interests, one must first understand the drivers leading to greater economic inequality, which is a crucial proxy to track the welfare of weaker constituencies. As we have shown elsewhere, the diminished position of such constituencies is not driven by corporate governance rules and norms, but rather by other factors, including increased concentration and monopsony in labor markets, the decline of unions and collective bargaining protections, tax policy, and financial deregulation, among many others. ${ }^{54}$ Thus, to benefit weaker constituencies, regulatory reform in

48. Id. at 412 n. 42 .

49. Id. at 429 (portraying the stakeholder approach as not a "fundamental revolution," but instead "a responsible evolution, insufficient in itself, but useful nonetheless").

50. Mayer, Shareholderism Versus Stakeholderism, supra note 43, at 9.

51. Id.

52. Id. at 10 ("In promoting long-term shareholder welfare, enlightened shareholder capitalism makes accountability of management hopelessly imprecise, while corporate purpose and values make it laser sharp.").

53. Id. at 11 .

54. Gatti \& Ondersma, supra note 7, at 10-11, 46-57. Additionally, a recent paper by Stansbury and Summers considers shareholder primacy as one of the contributing factors to decreased worker power. See Stansbury \& Summers, supra note 6, at 9 (arguing that the decline in union bargaining power and increased shareholder advocacy will result in labor and wage cuts). Similarly, Zohar Goshen and Doron Levit have recently argued that the push for stronger corporate governance stemming from 
these areas should have priority over indirect corporate governance initiatives or measures. ${ }^{55}$

Here, we focus on one constituency-workers-and on areas of reform that, for various reasons, currently fly under the radar of national politics: (a) countering firm concentration and labor monopsony, (b) strengthening labor market institutions to promote collective action among workers, (c) raising the minimum wage, and (d) tackling abuses in labor outsourcing and in the treatment of gig workers. In Section II.A, we review the evidence showing that these issues are pertinent to advancing the position of workers. Then, in Section II.B, we discuss the merits of some existing proposals that would address these areas of concern. To be clear, as the title of Part II suggests, the ensuing content does not purport to exhaust all areas of intervention; rather, it represents a selection based off what we consider high priorities.

\section{A. What Hurts Workers: Some Evidence}

\section{Firm Concentration and Labor Monopsony}

Although antitrust policy has historically focused on consumer welfare, ${ }^{56}$ an equally critical issue is that anticompetitive behavior by firms results in

shareholder pressures over several decades (from hostile takeovers to common ownership by index funds, via the rise of institutional investors and hedge fund activism) has resulted in less investment, thus depressing the labor market and keeping wages stagnant. See Zohar Goshen \& Doron Levit, Common Ownership and the Decline of the American Worker 1 (Eur. Corp. Governance Inst., Law Working Paper No. 584/2021, 2021), https://papers.ssrn.com/sol3/papers.cfm?abstract_id=3832069 [https:// perma.cc/VC7L-6D6T]. In their view, common ownership contributes to labor monopsony in all firms with strong corporate governance traits. Id. at 8-9 ("By switching firms en masse to strong governance, common owners create a labor market monopsony without resorting to collusion, and indeed, likely without intending to create one."). Tellingly, the solution advocated by Goshen and Levit has nothing to do with broadening the scope of director fiduciary duties but rather with breaking up giant index funds such as BlackRock. See id. at 49-59. We obviously do not dispute trade-offs between capital and labor. Nor do we dispute that worker losses translate into shareholder gains. We also reckon that shareholder pressure is a key input of managerial decisions. However, to understand the underlying causes of labor losses, one has to answer the following question: Could management have had its way of maximizing shareholder value if labor protections under law were not so minimal that workers' rights could in fact be thwarted? Certainly, since the takeover era of the 1980s, shareholder returns became more paramount than ever, and Corporate America had to adapt to such a new normal. See, e.g., Leo Strine, Jr., Human Freedom and Two Friedmen: Musings on the Implication of Globalization for the Effective Regulation of Corporate Behaviour, 58 U. TORONTO L.J. 241, 259-65 (2008) (noting that, in connection with the advent of takeovers, market institutions pressured management to fully embrace the shareholder primacy norm). But management was in a position to effect wealth transfers from workers to shareholders precisely because there was ample room to maneuver due to the scarce protections under labor and employment law, as illustrated by Section II.A.2. See Gatti \& Ondersma, supra note 7, at 62-63 (noting that "all the actions corporations took that harmed workers were made possible by the constant decline of protections for the labor force, both legal and institutional").

55. Gatti \& Ondersma, supra note 7, at 70-73.

56. See generally Herbert Hovenkamp, Post-Chicago Antitrust: A Review and Critique, 2001 ColuM. BUS. L. REV. 257 (describing how market power and not consumer welfare was the main concern of antitrust authorities); Jonathan B. Baker, Economics and Politics: Perspectives on the Goals and Future of 
hardship for workers. ${ }^{57}$ Among the many aspects in the nexus between concentration and societal welfare, antitrust experts have recently focused on the effects of less competition in hiring workers. Indeed, increasing degrees of firm market power (from oligopsony to monopsony) $)^{58}$ lead to imperfect labor markets. In the words of Ioana Marinescu and Eric Posner,

most labor markets are not highly competitive. Most labor markets are rural or semi-rural. Only a handful of employers cater to a thin population spread out over a large area. Even in densely populated areas, various frictions, including noncompetition agreements, prevent workers from easily finding new jobs. ${ }^{59}$

Antitrust, 81 FORDHAM L. REV. 2175 (2013) (same); Lina Khan \& Sandeep Vaheesan, Market Power and Inequality: The Antitrust Counterrevolution and Its Discontents, 11 HARV. L. \& POL'Y REV. 235, 23637 (2017) (same).

57. Aside from labor monopsony as illustrated in this section, there are several anticompetitive patterns affecting workers. One is the widespread practice of imposing noncompete agreements on employees, see Evan Starr, JJ Prescott \& Norman Bishara, Noncompetes in the U.S. Labor Force, 64 J.L. \& ECON. 53, 64 (2021) (finding that $13 \%$ of non-college-educated workers earning less than $\$ 40,000$ per year were bound by noncompetes), or explicit or implicit nonhire agreements with other large firms. As to the latter, many Silicon Valley firms were sued by the government for violating antitrust laws by entering into nonpoach agreements whereby they agreed to not hire from each other. See, e.g., Garrison v. Oracle Corp., 159 F. Supp. 3d 1044, 1053-55 (N.D. Cal. 2016); United States v. eBay, Inc., 968 F. Supp. 2d 1030, 1033 (N.D. Cal. 2013); In re High-Tech Emp. Antitrust Litig., 985 F. Supp. 2d 1167, 1172-73 (N.D. Cal. 2013). Although the various cases ultimately settled, they cast a light on an ongoing practice that alarmed authorities, so much so that the U.S. government issued guidelines clarifying that nonpoach agreements are illegal even if implicit. ANTITRUST DIV., U.S. DEP'T OF JUST. \& Fed. TRADE COMm'N, ANTITRust Guidance FOR Human Resource Professionals 3 (2016), https://www.justice.gov/atr/file/903511/download [https://perma.cc/Y5WC-4TXQ]. The FTC is currently considering a restriction to noncompete agreements. Non-Competes in the Workplace: Examining Antitrust and Consumer Protection Issues, FED. TRADE COMM'N (Jan. 9, 2020, 8:30 AM), https:/www.ftc.gov/news-events/events-calendar/non-competes-workplace-examining-antitrust-

consumer-protection-issues [https://perma.cc/XZ6Q-4FH9]. Another type of firm practice impacting worker welfare is the ability to impose vertical restraints to control and restrict less powerful affiliates (and their workers): such a practice is at the core of business models of franchise chains and online labor platforms such as Uber. See, e.g., Marshall Steinbaum, Antitrust, the Gig Economy, and Labor Market Power, 82 LAW \& CONTEMP. PROBS. 45, 46-56 (2019); Sanjukta Paul, Fissuring and the Firm Exemption, 82 LAW \& CONTEMP. PROBS. 65, 66 (2019); see also infra Section II.A.4.

58. A monopsony is the mirror image of a monopoly: a market where there is only one buyer, in this case a single employer; similarly, an oligopsony is a market with very few buyers/employers. Roger D. Blair \& Jeffrey L. Harrison, Antitrust Policy and Monopsony, 76 CORNELL L. REV. 297, 297-98, 308 (1991); see also HEATHER BOUSHEY, UNBOUND: HOW INEQUALITY CONSTRICTS OUR ECONOMY AND WHAT WE CAN DO ABOUT IT 131 (2019) ("There are more and less extreme examples of monopsony. It used to be that if you were trained as an astronaut, your only real employer option was NASA (now, of course, you might be able to get a job with SpaceX). If you're a nurse, you might have a variety of hospitals to choose from in your community, but it is increasingly likely that they are all owned by the same firm, reducing your bargaining power.").

59. Ioana Marinescu \& Eric A. Posner, Why Has Antitrust Failed Workers?, 105 CORNELL L. REV. 1343, 1346 (2020). 
This results in wage suppression for workers ${ }^{60}$ and employer labor cartels. ${ }^{61}$

Decreasing levels in the labor share have been associated with unprecedented high levels of concentration and corporate profits, in large part derived from merger activity. ${ }^{62}$ Also, thanks to concentration, we have experienced what has been described as the rise of "superstar firms" (in tech, finance, retail, and media) whose employees manage to capture higher wages than peers working for other firms; as observed by many, the income inequality of today occurs less within firms than between firms. ${ }^{63}$ Finally, market concentration increases firms' political clout, leading to regulatory capture and making reforms, especially progressive ones, ${ }^{64}$ much harder ${ }^{65}$ Firm concentration has greatly increased over recent decades ${ }^{66}$ and a growing body

60. See id. at 1345-46 ("A labor monopsony exists when lack of competition in the labor market enables employers to suppress the wages of their workers."); Suresh Naidu, Eric A. Posner \& Glen Weyl, Antitrust Remedies for Labor Market Power, 132 HARV. L. REV. 536, 539-40 (2018) (noting that, despite the fact that antitrust law prohibits firms from restricting competition in labor markets, just as it does with respect to products markets, antitrust enforcement has focused almost exclusively on product markets and too little on labor markets); see also José Azar, Ioana Marinescu \& Marshall I. Steinbaum, Labor Market Concentration, J. HUM. RES. 1, 16 (May 2020) (indicating that a 10\% increase in labor market concentration depresses wages by approximately 1.4\%). Data does indicate that high concentration is "robustly associated with lower wages." Ioana Marinescu \& Herbert Hovenkamp, Anticompetitive Mergers in Labor Markets, 94 IND. L. REV. 1031, 1047 \& n.98 (2019) (citing several empirical studies).

61. W. Todd Miller \& Donald I. Baker, Antitrust Indictments for Employer Restraints Against Employees, BAKER \& MILLER PLLC (Jan. 14, 2021), https://bakerandmiller.com/antitrust-indictmentsfor-employer-restraints-against-employees/ [https://perma.cc/FS4F-GXCV] (describing recent enforcement initiatives by the Antitrust Division of the DOJ against an employer for agreeing to reduce wages with a competitor and "a corporation for conspiring with two competing employers to allocate a medical employment market by agreeing not to solicit each other's senior employees").

62. See Simcha Barkai, Declining Labor and Capital Shares, 75 J. FIN. 2421, 2459 (2020); Gauti Eggertsson, Jacob A. Robbins \& Ella Getz Wold, Kaldor and Piketty's Facts: The Rise of Monopoly Power in the United States 5 (Nat'l Bureau of Econ. Rsch., Working Paper No. 24287, 2018), https://www.nber. org/papers/w24287 [https://perma.cc/FS4F-GXCV].

63. See Erling Barth, Alex Bryson, James C. Davis \& Richard Freeman, It's Where You Work: Increases in Earnings Dispersion Across Establishments and Individuals in the United States, $34 \mathrm{~J}$. LAB. ECON. S67, S68 (2016) (finding that "most of the increased variance in earnings among individuals is associated with the increased variance of average earnings among the establishments where they work"); Jae Song, David J. Price, Fatih Guvenen, Nicholas Bloom \& Till von Wachter, Firming Up Inequality, 134 Q.J. ECON. 1, 3 (2019). See generally David Autor, David Dorn, Lawrence F. Katz, Christina Patterson \& John Van Reenen, The Fall of the Labor Share and the Rise of Superstar Firms, 135 Q.J. ECON. 645 (2020) (arguing that the fall in labor share is linked to the rise of "superstar firms").

64. For a discussion of corporate efforts to oppose worker rights, see infra Section III.A.2.

65. See Martin Gilens \& Benjamin I. Page, Testing Theories of American Politics: Elites, Interest Groups, and Average Citizens, 12 PERSPS. ON POL. 564, 565, 576 (2014); THOMAs PHILIPPON, ThE GreAt REVERSAL: HOW AMERICA GAVE UP ON FrEe MARKETS 9-10 (2019); see also Mara Faccio \& Luigi Zingales, Political Determinants of Competition in the Mobile Telecommunication Industry (Nat'1 Bureau of Econ. Rsch., Working Paper No. 23041, 2017), http://www.nber.org/papers/w23041 [https://perma.cc/N9KR-A8F6].

66. A study by President Obama's Council of Economic Advisers found that most industries have seen increases in the revenue share enjoyed by the 50 largest firms between 1997 and 2012. See COUNCIL OF ECON. ADVISERS ISSUE BRIEF, BENEFITS OF COMPETITION AND INDICATORS OF 
of literature points to lack of competition as one of the main factors leading to inequality. ${ }^{67}$

In sum, recent legal and economic literature has shed light on a particular dimension of concentration: its nexus with labor market power and wage suppression. ${ }^{68}$ This line of work confirms that more concentration leads to increased labor market power, ${ }^{69}$ which results in lower levels of employment and in wage suppression. ${ }^{70}$ Employers with monopsony power can save labor

MARKET POWER 1, 4 (2016), https://obamawhitehouse.archives.gov/sites/default/files/page/files/ 20160414_cea_competition_issue_brief.pdf [https://perma.cc/FD6Z-XV96]. Another study shows that, in the last two decades, over $75 \%$ of U.S. industries have experienced an increase in concentration levels, which has led to higher profit margins and more profitable M\&A deals, but no sign of increased operational efficiency, thus suggesting that value is derived from greater market power. Gustavo Grullon, Yelena Larkin \& Roni Michaely, Are U.S. Industries Becoming More Concentrated?, 23 REV. FIN. 697, 697 (2019); see also Autor et al., supra note 63, at 663 (noting that "according to all measures of sales concentration, industries have become more concentrated on average"). Other research finds that firm markups have steadily risen from $21 \%$ in the 1980 s to nearly $61 \%$ in 2016 , an increase attributable almost exclusively to firms that already had the highest markups. Jan De Loecker, Jan Eeckhout \& Gabriel Unger, The Rise of Market Power and the Macroeconomic Implications, 135 Q.J. ECON. 561, 562, 566 (2020) (arguing that the increase explains the declining labor share, lower wages for lowskilled workers, and diminishing output growth). See generally Gatti \& Ondersma, supra note 7, at 40 (mentioning studies that focus on concentration in different sectors).

67. Jason Furman \& Peter OrSZAG, A Firm-Level Perspective on the Role of RENTS IN THE RISE IN INEQUALITY 2 (2015), https://obamawhitehouse.archives.gov/sites/default/ files/page/files/20151016_firm_level_perspective_on_role_of_rents_in_inequality.pdf [https://perma. cc/N2AU-3VH6] ("[A] rising share of firms are earning super-normal returns on capital ... workers at those firms are both producing and sharing in those super-normal returns, driving up wage inequality; and ... the high returns to labor and capital at those firms reduces labor mobility by discouraging workers from leaving firms that earn higher rents."). This study draws on literature showing that much of the growth of earnings inequality among workers is between firms and not within them. See, e.g., Barth et al., supra note 63, at S68; Song et al., supra note 63, at 3-4. A study by labor economists has found that concentration in the average U.S. labor market is high and that markets with higher concentration are associated with lower posted wages. See Azar et al., supra note 60, at 15 (finding that higher labor concentration leads to lower wages); see also Marinescu \& Hovenkamp, supra note 60, at 1047 (discussing empirical evidence showing that market concentration depresses wages). According to these studies, the increase in value of U.S. firms has occurred at the expense of consumers and the workforce, with negative ripple effects on investments, dynamism, and entrepreneurship. See Grullon et al., supra note 66, at 700 (discussing the impact of market concentration on workers and the wider market); see also Germán Gutiérrez \& Thomas Philippon, Declining Competition and Investment in the U.S. 1-3 (Nat'l Bureau of Econ. Rsch., Working Paper No. 23583, 2017), https://www.nber.org/papers/ w23583.pdf [https://perma.cc/BNG4-33M8] (showing that rather than trickling down to benefit the overall system, higher profits tend to be internalized by stockholders and top managers with stock options, by virtue of share buy-backs and dividend distributions).

68. See supra note 60 and accompanying text.

69. David Berger, Kyle Herkenhoff \& Simon Mongey, Labor Market Power 1 (IZA Inst. of Lab. Econ., Discussion Paper No. 12276, 2019), http://ftp.iza.org/dp12276.pdf [https://perma.cc/M34MMJUR] ("One intuitive source of market power is that there may be few firms in a local labor market and these firms understand that their hiring and wage setting decisions affect the local labor market's overall wage and employment levels. Firms that have a significant impact on local labor market conditions are able to maximize profits by hiring fewer workers in order to pay lower wages.").

70. Id.; see also Azar et al., supra note 60, at 1 (quantifying the level of labor market concentration across a wide range of occupations and for almost every commuting zone in the United States, and 
costs by suppressing wages and degrading working conditions-although some workers will quit as a result, an employer with monopsony power gains more in reduced labor costs than it loses from lower production. ${ }^{71}$ Both types of workers - those who continue working and those who quit-suffer from this state of affairs, and there is resulting harm to the economy from reduced production. ${ }^{72}$ Indeed, several industries that have experienced a recent wave of consolidation have also experienced a reduction of workers' wages. ${ }^{73}$

All told, ample evidence indicates that market concentration has weakened workers' position and has contributed to inequality. ${ }^{74}$

\section{Weakening of Labor Market Institutions and Worker Protections}

Weakened worker protections are key determinants of economic inequality. Alan Krueger argued that "[m]onopsony power has probably always existed in labor markets, but the forces that traditionally counterbalanced monopsony power and boosted worker bargaining power have eroded in recent decades." ${ }^{" 75}$ According to Anna Stansbury and Larry Summers, "the decline in worker power is one of the most important structural changes to have taken place in the U.S. economy in recent decades." 76

It is no secret that the United States offers scant protections for workers. Traditionally, its legal and industrial systems have provided bare-bones rights to workers when compared to other economically advanced nations. ${ }^{77}$ Since the

finding that labor market concentration in the average market is high, and higher concentration is associated with significantly lower posted wages); Naidu et al., supra note 60, at 537. According to Naidu et al., wage suppression results in (a) less income for people employed in concentrated labor markets; (b) the redistributive effect of an income reduction for those who rely on labor for the benefit of those who rely on capital and profit from a firm's market power; (c) underemployment of labor (at lower wages, some workers decide to exit the labor force or refuse to take available jobs-this is the waste or deadweight loss of monopsony and less investment in skills and education, thus stifling growth); and (d) a burden on the government for lost taxes and greater expenditures on social programs, such as disability, unemployment, and so forth. Id. at 537-38, 558 (estimating that "monopsony power in the U.S. economy reduces overall output and employment by $13 \%$, and labor's share of national output by $22 \% "$ ).

71. Marinescu \& Posner, supra note 59, at 1351.

72. Id.

73. Naidu et al., supra note 60 , at 546-47 (mentioning that mergers in the airline industry suppressed wages for pilots, flight attendants, and airline mechanics, that consolidation in the hospital sector created monopsonistic markets for nurses in rural areas, and that the meatpacking industry almost entirely operates in rural areas and is subject to monopsonistic dynamics).

74. It is therefore no surprise that recent labor economics literature has devoted renewed attention to monopsony and oligopsony. See Arindrajit Dube, Jeff Jacobs, Suresh Naidu \& Siddharth Suri, Monopsony in Online Labor Markets, 2 AM. ECON. REV. 33, 33 (2020).

75. Alan B. Krueger, Reflections on Dwindling Worker Bargaining Power and Monetary Policy, Luncheon Address at the Jackson Hole Economic Symposium 271 (Aug. 24, 2018), https://www. kansascityfed.org/documents/6984/Lunch_JH2018.pdf [https://perma.cc/D5W2-V2WL].

76. Stansbury \& Summers, supra note 6, at 7.

77. See James Gray Pope, A Brief History of United States Labor and Employment Law, in THE OXFORD INTERNATIONAL ENCYCLOPEDIA OF LEGAL HISTORY 477, 484 (Stanley N. Katz ed., 2009) 
1980s, neoliberal policies across the Atlantic resulted in a scaling back of worker protections in the name of enhancing flexibility and efficiency in labor markets. ${ }^{78}$ Economists observed a link between income inequality, on the one hand, and protections afforded to workers by a country's legal system and its labor market institutions, on the other. ${ }^{79}$

The protections offered by labor market institutions in the United States are sparse. First, under the centerpiece of labor legislation, the National Labor Relations Act ("NLRA"), ${ }^{80}$ entire categories of workers - and arguably some of the weakest ones, such as domestic and agricultural workers-are completely

[hereinafter Pope, A Brief History]; Alan Hyde, The Idea of the Idea of Labour Law: A Parable, in THE IDEA OF LABOUR LAW 88, 90, 92-93 (Guy Davidov \& Brian Langille eds., 2011) (describing the alarming deterioration of labor legislation, union activity, and strikes throughout the twentieth century); Simon Deakin, Jonas Malmberg \& Prabirjit Sarkar, How Do Labour Laws Affect Unemployment and the Labour Share of National Income? The Experience of Six OECD Countries, 1970-2010, 153 INT'L. LAB. REV. 1, 12 (2014); JAKE ROSENFELD, WHAT UNIONS NO LONGER DO 12-15 (2014); Kate Andrias, The New Labor Law, 126 YALE L.J. 2, 16 (2016) (noting how the NLRA "excluded millions of the most vulnerable workers... from its coverage"); Leo Strine, Jr., Made for This Moment: The Enduring Relevance of Adolf Berle's Belief in a Global New Deal, 42 SEATTLE U. L. REV. 267, 283-86 (2019) (explaining that the lack of strong "social democratic protections for workers common in the Western nations" led to the "substantial weakening" of U.S. labor unions).

78. See Colin Crouch, The Strange Non-Death OF NeOliberalism 18 (2011) (noting that the neoliberal platform on labor issues had become mainstream by the mid-1990s with both the OECD and the EU endorsing the dismantling of workers' and other social rights); Deakin et al., supra note 77, at 1 (noting that starting in 1994 the OECD argued for "liberalizing labour laws as part of a strategy for enhancing labour market flexibility and thereby boosting job creation," and that "[d]uring the 2000s similar arguments were made by the World Bank through its Doing Business initiatives").

79. See David Card, Thomas Lemieux \& W. Craig Riddell, Unions and Wage Inequality, 25 J. LAB. RSCH. 519, 555 (2004) (finding that the decline in union density "explains a significant fraction of the growth in wage inequality in the United States and United Kingdom"); ANTHONY ATKINSON, INEQUALITY: WHAT CAN BE DONE? 135-36 (2016) (mentioning the explosion of "nonstandard employment" such as part-time, fixed-term, temp-agency, seasonal, casual, family work, as well as selfemployment); FLORENCE JAUMOTTE \& CAROLINA OSORIO BUITRON, INEQUALITY AND LABOR MARKET INSTITUTIONS 7 (2015), https://www.imf.org/external/pubs/ft/sdn/2015/sdn1514.pdf [https://perma.cc/2AF3-ALZK] (finding that "lower union density is associated with a rise of top income shares"); Henry S. Farber, Daniel Herbst, Ilyana Kuziemko \& Suresh Naidu, Unions and Inequality over the Twentieth Century: New Evidence from Survey Data, 136 Q.J. ECON. 1325, 1326-27 (2021) (looking at union density starting from 1936 and finding that "measures of inequality have moved inversely with union density"); Josh Bivens \& Heidi Shierholz, What Labor Market Changes Have Generated Inequality and Wage Suppression?, ECON. POL'Y INST. (Dec. 12, 2018), https://www.epi.org/publication/what-labor-market-changes-have-generated-inequality-and-wagesuppression-employer-power-is-significant-but-largely-constant-whereas-workers-power-has-beeneroded-by-policy-actions/ [https://perma.cc/V2B4-9BHC] (arguing that the biggest change in labor market dynamics has been the "collapse of worker power," which "has been overwhelmingly driven by conscious policy decisions"); JOSEPH E. STIGLITZ, PEOPLE, POWER AND PROFITS: PROGRESSIVE CAPITALISM FOR AN AGE OF DISCONTENT 86 (2019) (arguing that legislation affecting unions and workers' rights weakened workers' bargaining power).

80. National Labor Relations (Wagner) Act, Pub. L. No. 74-198, 49 Stat. 449 (1935) (codified as amended at 29 U.S.C. $\S \S 151-169)$. 
excluded from its coverage. ${ }^{81}$ The NLRA is also quite obsolete in that it does not extend its reach to independent contractors, and therefore does not reach a large portion of the modern labor force. ${ }^{82}$ Crucially, the NLRA puts unions at a disadvantage vis-à-vis employers in unionization efforts ${ }^{83}$ by, among other things, giving employers an opportunity to delay the unionization referendum. ${ }^{84}$ Importantly, the U.S. labor system is anchored to a firm-level, dual-bargaining system-union vs. particular employer-whereas, in most jurisdictions abroad, unions operate at the sectoral level and interact not just with employers but also with the government, which actively participates in the bargaining process. ${ }^{85}$ As a result, American unions have very limited political clout. $^{86}$ Furthermore, the remedy apparatus is rather ineffective, with cumbersome enforcement mechanisms and mild penalties for employers who violate the NLRA. ${ }^{87}$ In particular, there are no cash penalties for employers who

81. See Andrias, supra note 77 , at 16 . For evidence that racial discrimination informed this policy choice, see MEHRSA BARADARAN, THE COLOR OF MONEY: BLACK BANKS AND THE RACIAL WEALTH GAP 101-03 (2017).

82. See infra Section II.A.4.

83. Andrias, supra note 77 , at 25 ("Unions are denied physical access to the workplace during an organizing campaign, but employers are permitted to compel employee presence for antiunion communication."). For a holistic view of employees' choice in the context of unionization, see generally Benjamin I. Sachs, Enabling Employee Choice: A Structural Approach to the Rules of Union Organizing, 123 HARV. L. REV. 655, 660 (2010) ("It is at least somewhat more difficult for employees to depart from the nonunion default and choose unionization than it would be for employees to depart from a union default and choose nonunion bargaining.").

84. Paul Weiler, Promises To Keep: Securing Workers' Rights to Self-Organization Under the NLRA, 96 HARV. L. REV. 1769, 1777 n.24 (1983).

85. Andrias, supra note 77 , at $6,15$.

86. If the collective action tools offered by labor law are of little help, the individual protections stemming from employment law are even less impactful. Employment law consists of a wide range of federal laws and doctrines that work independently of any collective effort in the workplace and bestow a series of individual rights and protections for the employee: antidiscrimination on the basis of race, sex, sexual orientation, national origin, and other protected characteristics; guaranteed minimum standards and fair treatment, such as minimum wages, maximum hours, safe working conditions; and family leave. While employment law should in theory function as a floor from which employees and/or unions can extract better terms, in practice it has conflicted with the very philosophy of labor law, as its individual-centered structure atrophied solidarity. Id. at 37-40. Generally, enforcement is lax even with rampant violations, especially for outsourced workers. See DAVID WEIL, THE FISSURED WORKPlACE: WHY WORK BECAME SO BAD FOR SO MANY AND WHAT CAN BE DONE TO IMPROVE IT 214-17, 270 (2014) [hereinafter WEIL, FISSURED WORKPLACE]; Andrias, supra note 77, at 39. Taking employers to court is extremely hard given that mandatory arbitration clauses are ubiquitous nowadays following the Supreme Court's blessing in Epic Systems Corp. v. Lewis, 138 S. Ct. 1612 (2018). See Cynthia Estlund, The Black Hole of Mandatory Arbitration, 96 N.C. L. REV. 679, 695, 699 (2018) [hereinafter Estlund, Black Hole]. And, more generally, employment law rights are of limited impact if compared to what is normally obtained though collective bargaining. See Andrias, supra note 77 , at $39-40$.

87. Andrias, supra note 77, at 5-6; Alan Hyde, The Crisis in the US Litigation Model of Labour Rights Enforcement, in ONE LAW FOR ALL?: WEBER V. ONTARIO HYDRO AND CANADIAN LABOUR LAW 301 (Elizabeth Shilton \& Karen Schucher eds., 2017); Janice Fine, Solving the Problem from Hell: Tripartism as a Strategy for Addressing Labour Standards Non-Compliance in the United States, 50 OSGOODE HALL 
bargain in bad faith, and employers retain the right to permanently replace striking workers. ${ }^{88}$ More troublingly, the meager baseline of statutory protections provided by the NLRA has been further eroded by courts, especially those sensitive to pressures from the employers' lobby. ${ }^{89}$ In parallel, deregulation in certain sectors like transportation and telecommunications allowed entry by nonunionized firms, which has contributed to a steeper decrease in the overall power of unions in such sectors, as unionized workers have made concessions to make their firms competitive in the new environment. $^{90}$

Overall, this system of weak protections has produced some troubling outcomes: union density has been constantly declining, ${ }^{91}$ employers have a right to fire employees at will, ${ }^{92}$ layoffs can take place more freely than in other countries because of the lack of employment protection legislation, ${ }^{93}$ the overall system of labor standards enforcement is ineffective, ${ }^{94}$ and collective bargaining plays a very small role in the overall U.S. economy (and never takes place at a centralized level) ${ }^{95}$ Despite polls showing that tens of millions of workers would prefer to be represented by a union, only 50,000-70,000 employees win representation each year-and even then it can take years for a union to obtain a collective bargaining agreement; indeed, some never do. ${ }^{96}$

This system of weak protections has also played a significant role in the rise of inequality. A recent study by Henry Farber, Daniel Herbst, Ilyana Kuziemko, and Suresh Naidu found that the decrease of union density has increased inequality. ${ }^{97}$ Labor economists have also observed that "unions tend

L.J. 813, 820-23 (2013); Ross Eisenbrey, Employers Can Stall First Union Contract for Years, ECON. POL’Y INST. (May 20, 2009), https://www.epi.org/publication/snapshot_20090520/ [https://perma.cc/ $5 \mathrm{QPF}-\mathrm{QH} 3 \mathrm{~N}]$.

88. Eisenbrey, supra note 87.

89. Andrias, supra note 77, at 17 ("The [U.S. Supreme] Court... undercut the [NLRA]'s protection of the right to strike, made it easier for employers to oppose union campaigns, and generally shored up managerial rights of control over the workplace.").

90. Id. at 22-23.

91. Press Release, Bureau of Lab. Stat., U.S. Dep't of Lab., Union Members-2020 (Jan. 22, 2021), https://www.bls.gov/news.release/pdf/union2.pdf [https://perma.cc/7QG2-4G35].

92. Cynthia L. Estlund, How Wrong Are Employees About Their Rights, and Why Does It Matter?, 77 N.Y.U. L. REV. 6, 8 (2002) (noting that in the United States, at-will employment is the default everywhere but Montana); Andrias, supra note 77, at 40.

93. Rachel Arnow-Richman, Just Notice: Re-Reforming Employment at Will, 58 UCLA L. REV. 1, 4-6 (2010) (mentioning that American employment law scholars are keen to reform at-will employment only for "arbitrary or socially condemnable terminations," not for business-driven mass layoffs).

94. See supra note 87 and accompanying text.

95. ROSENFELD, supra note 77, at 21.

96. Eisenbrey, supra note 87.

97. Farber et al., supra note 79, at 1325-26; see also Heidi Shierholz, Working People Have Been Thwarted in Their Efforts To Bargain for Better Wages by Attacks on Unions, ECON. POL'Y INST., https://www.epi.org/publication/labor-day-2019-collective-bargaining/ [https://perma.cc/4XD 
to compress wage structures and reduce inequality." ${ }^{98}$ In particular, data suggest that "unions played a significant role in reducing income inequality at midcentury," when unions were at their peak and inequality at its lowest. ${ }^{99}$ Farber, Herbst, Kuziemko, and Naidu's study also shows that union density has a negative effect on standard measures of inequality such as the skill premium, the 90/10 ratio, the Gini coefficient, and the top-ten-percent income share ${ }^{100} \mathrm{~A}$ 2003 study by the World Bank concluded that "workers who belong to trade unions earn higher wages, work fewer hours, receive more training, and have longer job tenure on average than their nonunionized counterparts." ${ }^{101}$ Another recent study articulated that the erosion of collective bargaining over the past four decades has come at a cost of $\$ 3,250$ per year to the median worker, and has driven $33 \%$ of the wage-gap growth between high- and middle-wage earners. ${ }^{102}$ Unsurprisingly, studies show that these low protections more severely affect racial minorities and members of the LGBTQ community. ${ }^{103}$ Studies also show that unionization reduces the racial wage gap. ${ }^{104}$

Despite the benefits of unions to workers, unions have historically played a much smaller role in the United States than in other advanced economies, ${ }^{105} \mathrm{a}$

H-GB8R] (Sept. 9, 2019) (mentioning that "a worker covered by a union contract earns $13.2 \%$ more than a peer with similar education, occupation, and experience in a nonunionized workplace in the same sector" and that "the decline of unionization has played a significant role in the expansion of the blackwhite wage gap").

98. Williams J. Collins \& Gregory T. Niemesh, Unions and the Great Compression of Wage Inequality in the US at Mid-Century: Evidence from Local Labour Markets, 72 ECON. HIST. REV. 691, 692 (2019). The literature documenting the flattening of wage dispersion by unions is vast. See, e.g., RICHARD B. FREEMAN \& JAMES L. MEDOFF, WHAT DO UNIONS DO? 43-60 (1984); Card et al., supra note 79, at 555; Farber et al., supra note 79, at 1326; John DiNardo, Nicole M. Fortin \& Thomas Lemieux, Labor Market Institutions and the Distribution of Wages, 1973-1992: A Semiparametric Approach, 64 ECONOMETRICA 1001, 1039 (1996); Amanda Gosling \& Thomas Lemieux, Labour Market Reforms and Changes in Wage Inequality in the United Kingdom and the United States (Nat'l Bureau of Econ. Rsch., Working Paper No. 8413, 2001), https://www.nber.org/papers/w8413 [https://perma.cc/JK93-ZW85]; Bruce Western \& Jake Rosenfeld, Unions, Norms, and the Rise in U.S. Wage Inequality, 76 AM. SOCIO. REV. 513, 516-17 (2011) (highlighting the array of literature that documents the flattening effect of wage dispersion by unions).

99. Farber et al., supra note 79, at 1327, 1355 ("During these peak-density years [(1940s through 1960s)], union households were also more likely to be nonwhite than before or after.").

100. Id. at $1355-61,1380$.

101. Richard B. Freeman, Labour Market Institutions Without Blinders: The Debate over Flexibility and Labour Market Performance 7 (Nat'l Bureau of Econ. Rsch., Working Paper No. 11286, 2005), https:// www.nber.org/system/files/working_papers/w11286/w11286.pdf [https://perma.cc/AD5S-UTLY].

102. Lawrence Mishel, The Enormous Impact of Eroded Collective Bargaining on Wages, ECON. POL'Y INST. (Apr. 8, 2021), https://www.epi.org/publication/eroded-collective-bargaining/ [https://perma. cc/8NNU-8PJS].

103. See Gatti \& Ondersma, supra note 7, at 49 n.276.

104. See, e.g., Jake Rosenfeld \& Meredith Kleykamp, Organized Labor and Racial Wage Inequality in the United States, 117 AM. J. SocIO. 1460, 1489-90 (2012).

105. Jelle Visser, ICTWSS: Database on Institutional Characteristics of Trade Unions, Wage Setting, State Intervention and Social Pacts in 55 Countries Between 1960 and 2018 (2020), https://aias.s3.eu-central- 
role that has been receding over the years. ${ }^{106}$ In the private sector of the United States, union density was $6.3 \%$ in $2020,{ }^{107}$ almost half of what it was just nine years earlier. ${ }^{108}$ In addition, unlike elsewhere, the level of union coverage-that is, the fraction of workers covered by wage bargaining by a union over the total workforce-does not significantly exceed the level of union density $(7.2 \%$ in 2020). ${ }^{109}$ In places where the difference between the two levels is significant, the excess coverage makes it more pointless for an employer to resist unionization efforts. ${ }^{110}$ But, because union density and coverage are so low, collective bargaining is unavailable to a staggering $93 \%$ of private-sector wage and salary workers in the United States. ${ }^{111}$

In sum, there is substantial evidence that declining collective bargaining protections have contributed to the weakened position of workers.

\section{The Declining Minimum Wage}

Whether or not it is a primary contributor to inequality, the declining purchasing power of the minimum wage plays a major role in widening lowertail inequality in the United States, particularly for women. ${ }^{12}$ The problem with

1.amazonaws.com/website/uploads/20191107_ICTWSS_6_1_Dataset.xlsx [https://perma.cc/S5E4-5W WW].

106. See id. For an analysis of the reasons behind the decrease of union importance, see ROSENFELD, supra note 77, at 18-19 (mentioning that unemployment stemming from the recession between the late 1970s and the early 1980s, together with competition from abroad, weakened workers' bargaining leverage because pro-union workers became more at risk in an "employer market," and that firm closures resulted in a shift to nonunionized firms in the services and tech industries).

107. Table 3. Union Affiliation of Employed Wage and Salary Workers by Occupation and Industry, 20192020 Annual Averages, U.S. BUREAU LAB. STAT. (Jan. 21, 2021), https://www.bls.gov/ news.release/union2.t03.htm [https://perma.cc/TDF9-XZG9] [hereinafter Union Affiliation Annual Averages]. Union density is the fraction of workers registered with some union over the total workforce. SAMUEL Estreicher \& MATTHEW T. BOdie, LABOR LAW 40 (2d ed. 2020). The decline in union density occurred across different sectors, including some that traditionally had strong unions such as manufacturing and construction. Id. at 41-42.

108. TITO BOERI \& JAN VAN OURS, THE ECONOMICS OF IMPERFECT LABOR MARKETS 65 (2d ed. 2013) (reporting 2011 data compiled by Jelle Visser showing union density at 11\%). At its peak, union density was at $36 \%$ in 1953. ESTREICHER \& BODIE, supra note 107, at 41.

109. A union coverage of $7.2 \%$ means an excess coverage of only $0.9 \%$ (excess coverage is the difference between union coverage and union density). Union Affiliation Annual Averages, supra note 107. In other advanced economies, excess coverage is much higher, especially when union density is low. See BOERI \& VAN OURS, supra note 108, at 65 (reporting 2011 data compiled by Jelle Visser showing, among other things, excess coverages of $21 \%$ for Australia, $82 \%$ for France, and $43 \%$ for Germany).

110. See ROSENFELD, supra note 77, at 20.

111. See Union Affiliation Annual Averages, supra note 107. It is important to note that, by design, labor law does not cover certain important sectors (for example, agriculture and domestic jobs) and employee positions (for example, managers and supervisors). See ESTREICHER \& BODIE, supra note 107, at 60-68. Thus, the 93\% figure actually underestimates the true level of workers who are not protected by the core device of labor law.

112. Compare Thomas Piketty, Capital in the Twenty-First Century 388-90 (2014) (noting inequalities at the bottom of the wage distribution have closely followed the evolution of the 
the minimum wage is that, because of inflation, it becomes obsolete shortly after it is increased-the current federal minimum wage of $\$ 7.25$, which dates back to 2009 , on inflation-adjusted terms "is worth $70 \%$ of what it was in 1968 , and about a third of what it would be had it kept pace with productivity." in the absence of planned increases, or indexing, of the minimum wage, getting stuck in a loop is inevitable; policymakers have to periodically review the minimum wage's inflation-adjusted level and consider adjustments. By the time policymakers ultimately reassess the minimum wage, they are almost always forced to reengage in a debate over its overall merits, as Section II.B.3 illustrates. Of course, inertia-which is always a powerful force in policymaking-favors employers.

Currently the minimum wage is well below sustainability levels in many parts of the country. For reference, out of all the OECD members, the United States has the lowest ratio of minimum wage to median wage, which is a common measure to compare minimum wages across jurisdictions. ${ }^{114}$

\section{Figure 1. Minimum Wage to Medium Wage Ratio Members}

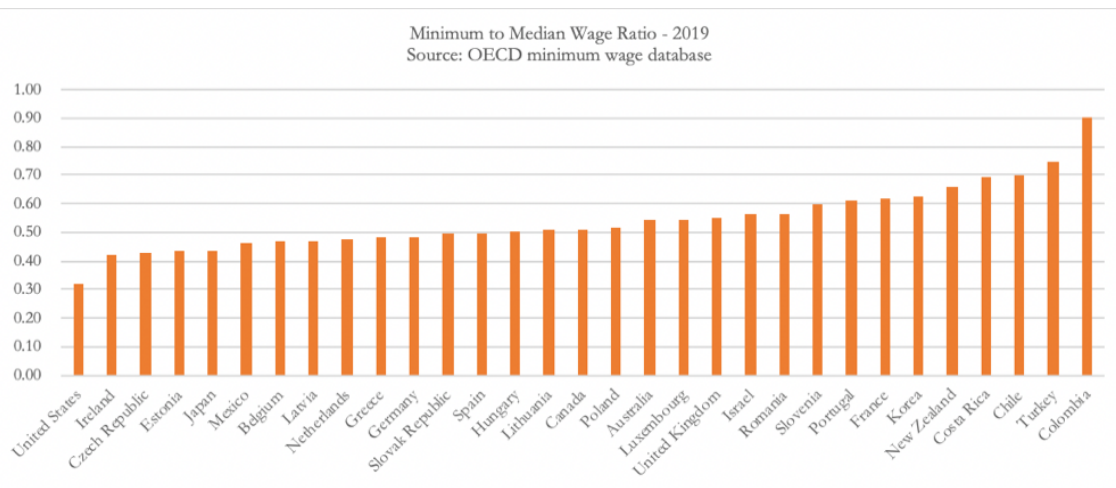

minimum wage), with David H. Autor, Alan Manning \& Christopher L. Smith, The Contribution of the Minimum Wage to US Wage Inequality over Three Decades, 8 AM. ECON. J. APPLIED ECON. 58, 88-89 (2016) (concluding that the declining minimum wage has not been a primary contributor for inequality among men).

113. Josh Eidelson, How the American Worker Got Fleeced. Over the Years, Bosses Have Held Down Wages, Cut Benefits, and Stomped on Employees' Rights. Covid-19 May Change That., BLOOMBERG BUSINESSWEEK (July 2, 2020), https://www.bloomberg.com/graphics/2020-the-fleecing-of-theamerican-worker/ [https://perma.cc/CN3E-SFAB].

114. See Minimum Relative to Average Wages of Full-time Workers, ORG. FOR ECON. COOPERATION \& DEV., https://stats.oecd.org/Index.aspx?DataSetCode=MIN2AVE [https://perma.cc/ E2P7-KHWK]. 
Unsurprisingly, worker advocates have been pressing legislatures and corporations to increase minimum wages; thus far, there have been no changes at the federal level since $2009 .{ }^{115}$

\section{Outsourcing and Gig Work}

Employers' practice of outsourcing labor and adopting other alternative work arrangements has been rampant in the last fifteen to twenty years. ${ }^{116}$ Many workers are no longer employees of the company for which they ultimately provide services. ${ }^{117}$ Instead, many are independent contractors or employed by third-party firms that do not directly supervise their labor. ${ }^{118}$ A recent study estimated that as many as $19 \%$ of all private-sector workers perform services under these arrangements. ${ }^{119}$ For example, many companies (including most hotel and motel companies) regularly outsource janitorial work and other cleaning related services. ${ }^{120}$ Apple directly employs only 63,000 workers, even though 750,000 workers are responsible for creating, manufacturing, packaging, and selling its products. ${ }^{121}$ Many cable companies outsource cable installation, and manufacturers often outsource packaging. ${ }^{122}$ Additionally, many franchise agreements are structured such that the franchisee is essentially a low-wage employee-except that, by virtue of not being categorized as an employee, the parent company is not bound by minimum-wage laws, overtime laws, workersafety laws, and so forth. ${ }^{123}$ Some companies-particularly in the gig worker economy-classify their workers as "independent contractors" and are thereby able to deny them many customary benefits and protections while still retaining

115. Minimum Wage Tracker, ECON. POL'Y INST., https://www.epi.org/minimum-wage-tracker/ [https://perma.cc/2P24-4UYR].

116. See generally WEIL, FISSURED WORKPLACE, supra note 86, at 168-77 (highlighting the vast discrepancy between the number of workers directly employed by leading manufacturers versus the number of workers that leading manufacturers actually depend on); Lawrence F. Katz \& Alan B. Krueger, Understanding Trends in Alternative Work Arrangements in the United States, 5 RSF 132, 133 (2019) (describing an uptick in alternative workers but warning of difficulty in capturing exact data); BOUSHEY, supra note 58, at 133.

117. See WEIL, FISSURED WORKPLACE, supra note 86 , at $2-4,7-8$. Over $80 \%$ of staff employed at hotels do not work for the hotel brand, but rather for another hotel franchise or management company. Id. at 7.

118. See id. at 7-9; Steinbaum, supra note 57, at 46 ("[E]mployers can evade [federal labor] law by re-classifying workers as either independent contractors or as employees of their contractors."); see also, e.g., Noam Scheiber, Is Gig Work a Job? Uber and Others Are Maneuvering To Shape the Answer, N.Y. TiMES (Mar. 26, 2019), https://www.nytimes.com/2019/03/26/business/economy/gig-economylobbying.html [https://perma.cc/U2K6-ABY8 (dark archive)].

119. See David Weil, Understanding the Present and Future of Work in the Fissured Workplace Context, 5 RSF 147, 151 (2019).

120. See WEIL, FISSURED WORKPLACE, supra note 86 , at $1-3$.

121. Id. at 7-8.

122. See id. at $2-3,118-20$.

123. See id. at 3,9 . 
control over them. ${ }^{124}$ As Catherine Fisk aptly put it, "[t]he huge growth of the platform economy has... enabled companies to coordinate vast workforces while insisting they have few actual employees." ${ }^{25}$ In addition, employers deprive both gig workers and franchise workers of coordination and collective bargaining rights-the irony of it is that businesses can do so by invoking antitrust law or the NLRA. ${ }^{26}$

Job outsourcing represents yet another contributor to growing wage inequality. ${ }^{127}$ Indeed, because employers can choose to keep certain workers within the firm and outsource other workers elsewhere, some workers offering specific services (think janitorial services) can sometimes rely only on one or two employers even if they operate at firms in competitive markets (think hotels). ${ }^{128}$ As a result, intrafirm mobility for such workers is almost impossible, which in turn depresses wages. ${ }^{129}$

\section{B. Policy Proposals}

If some key contributors to inequality and the weakening of workers' positions include labor market power, decreased labor protections and collective bargaining, a declining minimum wage, and increased outsourcing, it is paramount to consider specific proposals that have the potential to reverse such trends. Here, we review some specific proposals in the arenas of (1) expanding antitrust reach, (2) strengthening collective bargaining, (3) increasing the minimum wage, and (4) enhancing protections for gig workers.

\section{Addressing Concentration and Monopsony Power}

Antitrust has undoubtedly taken the center stage as of late, particularly in the wake of high-profile and still-developing enforcement initiatives brought by the government against tech giants such as Google and Facebook. In the fall

124. Steinbaum, supra note 57, at 56 ("This hybrid business model of total control but no responsibility as an employer is one optimized not only to the erosion of labor protections, but also to the erosion of antitrust's restrictions on vertical restraints."); see also Paul, supra note 57, at 66 ("[F]issured business[es] . . a are able to control smaller actors in their orbits without the censure of antitrust law ... [and antitrust law protects them] from any countervailing power that these smaller actors might bring to bear upon their relationships with them.").

125. Catherine L. Fisk, Work After the End of Employment-An Introduction, 82 LAW \& CONTEMP. PROBS. i, i (2019).

126. See Paul, supra note 57, at 65 (noting that workers and small enterprises are deprived of coordination rights as a result of antitrust law); Steinbaum, supra note 57, at 51 (noting that any attempt by workers to collectively bargain against both franchises and franchisors has been challenged by employers as an illegal secondary boycott under the definition of "joint employer" under the NLRA).

127. See Elizabeth Weber Handwerker \& James R. Spetzler, Increased Concentration of Occupations, Outsourcing, and Growing Wage Inequality in the United States 1 (Feb. 20, 2015) (unpublished manuscript), https://conference.iza.org/conference_files/inequality_2015/handwerker_ e20486.pdf [https://perma.cc/5SWR-EAGD]; BOUSHEY, supra note 58, at 133.

128. See Steinbaum, supra note 57 , at 47.

129. Id. at $47-48$. 
of 2020, the Justice Department (joined by several state attorneys general) accused Google of exercising monopolies over general search engine services and search advertising and of fostering anticompetitiveness through the use of exclusionary practices (such as requiring mobile and online platforms to sign exclusivity agreements making Chrome their default browser). ${ }^{130}$ The complaint alleges that Google's conduct reduces consumer choice, creates barriers to competition, and stifles innovation. ${ }^{131}$ In December of 2020, the Federal Trade Commission ("FTC") sued Facebook, alleging that Facebook's accumulation of companies like WhatsApp and Instagram had created a "moat" that (1) secures Facebook's unrivaled market presence in social networking services and (2) enables the company to control the advertising market attached to social networking. ${ }^{132}$ The complaint against Facebook alleged that the company hindered, suppressed, and deterred market entry-thereby stifling innovation and improvements in the industry ${ }^{133}$-and called for Facebook to divest Instagram and WhatsApp. ${ }^{134}$ However, in a surprising setback for the government, Judge Boasberg of the U.S. District Court for the District of Columbia threw out both lawsuits because, among other things, the FTC had failed to sufficiently prove that Facebook was a monopoly and that the acquisitions in question dated back to 2012 and $2014 .{ }^{135}$ Still, at the time of this writing, the case is not over: the judge gave the FTC thirty days to refile, which the FTC did in August. ${ }^{136}$ The FTC has also issued Special Orders to five large technology firms-Alphabet (parent of Google), Amazon, Apple, Facebook, and Microsoft-requiring them to provide information about prior acquisitions not reported to the antitrust agencies under the Hart-Scott-Rodino Act, ${ }^{137}$

130. Press Release, Off. of Pub. Affs., U.S. Dep't of Just., Three Additional States Ask Court To Join Justice Department Antitrust Suit Against Google (Dec. 17, 2020), https://www.justice. gov/opa/pr/three-additional-states-ask-court-join-justice-department-antitrust-suit-against-google [https://perma.cc/9LYF-NX4S].

131. Complaint at 7, United States v. Google LLC, No. 20-cv-03010 (D.D.C. Oct. 20, 2020).

132. Complaint at 8-9, Fed. Trade Comm'n v. Facebook, Inc., No. 20-cv-03590-JEB (D.D.C. Dec. 9, 2020).

133. See id. at $47-48$.

134. Id. at 51.

135. Cecilia Kang, Judge Throws Out 2 Antitrust Cases Against Facebook, N.Y. Times (June 28, 2021), https://www.nytimes.com/2021/06/28/technology/facebook-ftc-lawsuit.html?referringSource=article Share [https://perma.cc/6V7E-Q6K9 (dark archive)].

136. Brett Kendall, Facebook Hit with New Antitrust Suit from Federal Trade Commission, WALL ST. J. (Aug. 19, 2021), https://www.wsj.com/articles/facebook-hit-with-renewed-antitrust-lawsuit-as-ftctries-again-11629387483 [https://perma.cc/2KZ7-S6WN (dark archive)]. Facebook's motion to dismiss is currently pending. Cat Zakrzewski, Facebook Again Asks Judge To Dismiss FTC Antitrust Complaint, Arguing It Lacks 'Valid Factual Basis,' WASH. POST (Oct. 4, 2021), https://www. washingtonpost.com/technology/2021/10/04/facebook-ftc-antitrust-dismiss/ [https://perma.cc/NNL9LZ2D (dark archive)].

137. Hart-Scott-Rodino Antitrust Improvements Act of 1976, Pub. L. No. 94-435, 90 Stat. 1983 (codified as amended in scattered sections of 15,18 , and 28 U.S.C.). 
indicating that the suits against Google and Facebook are likely not the end of Washington's renewed interest in tech company antitrust concerns. ${ }^{138}$

The tension between Big Tech and the government is hardly the only topic deserving attention in this field: antitrust is also gaining traction as a remedy to tackle workers' decreasing leverage in labor markets. For instance, Suresh Naidu, Eric Posner, and Glen Weyl propose looking at workers' protection through an antitrust lens. ${ }^{139}$ In their view, although fully consistent with antitrust law, this approach has long been neglected because cases are considered tougher to litigate by a plaintiff ${ }^{140}$ and because of a long-held view by traditional economists that labor markets are competitive. ${ }^{141}$ However, as indicated earlier, the idea that all labor markets are competitive is no longer tenable. ${ }^{142}$ In reality, labor markets are actually considered more problematic from an antitrust perspective than product markets, as they are geographically more contained and present further complexities for workers, such as search frictions ${ }^{143}$ and matching. ${ }^{144}$ Marshall Steinbaum proposes both interpretative and policy

138. Press Release, Fed. Trade Comm'n, FTC to Examine Past Acquisitions by Large Technology Companies (Feb. 11, 2020), https://www.ftc.gov/news-events/press-releases/2020/02/ftc-examinepast-acquisitions-large-technology-companies [https://perma.cc/8TUJ-F5QZ].

139. Naidu et al., supra note 60 , at 539-41.

140. Id. at 543 ("[V]irtually no worker can hope to obtain damages in an antitrust action ... that would compensate her for the cost of litigation. And class actions brought by workers hardly ever succeed because workers-unlike consumers-are frequently in diverse positions, defeating the common interest requirement.").

141. Id. at 541-42.

142. See supra notes $57-61,68-73$ and accompanying text.

143. Existing employers are aware of the high search costs employees face when switching jobs and can opportunistically reduce compensation in light of these costs. See generally ALAN MANNING, MONOPSONY IN MOTION: IMPERFECT COMPETITION IN LABOR MARKETS 3-4 (2003) (noting that "[ $t]$ he existence of frictions gives employers potential market power over their workers").

144. For a description of matching, see Naidu et al., supra note 60, at 554-55:

[U]nlike in product markets, the preferences of both sides of the [labor] market affect whether a transaction is desirable.... In employment, the employer cares about the identity and characteristics of the employee and the employee cares about the identity and characteristics of the employer. Complexity runs in both directions rather than in one. Employers search for employees who are not just qualified, but also who possess skills and personality that are a good match to the culture and needs of that employer. At the same time, employees are looking for an employer with a workplace and working conditions that are a good match for their needs, preferences, and family situation. Only when these two sets of preferences and requirements "match" will a hire be made.

This two-sided differentiation is why low-skill workers may be as or even more vulnerable to monopsony than high-skill workers, despite possibly being less differentiated for employers. Low-skill workers may have less access to transportation, well-situated housing markets, child care options, and job information, and be more dependent on local, informal networks, all of which make jobs less substitutable and employers more differentiated.

Id. For a thorough critique of the neoclassical view that equates labor markets to product ones, see James Gray Pope, Contract, Race, and Freedom of Labor in the Constitutional Law of "Involuntary Servitude," 119 YALE L.J. 1474, 1554-56 (2010) (describing market malfunctions and imbalances of 
changes in antitrust law by advocating for an analysis of labor market impact in the merger review process and to counter the inequalities of gig and outsourced work. ${ }^{145}$ On the official front, the 2016 joint DOJ and FTC Antitrust Guidance for Human Resource Professionals made employment-related restraints a top priority of antitrust enforcement, which in late 2020 and early 2021 resulted in the first ever criminal indictments to employers for antitrust violations. ${ }^{146}$

In general, the Biden administration has signaled that it will seek stricter antitrust enforcement with the hiring of Jonathan Kanter at the DOJ Antitrust Division and Lina Kahn at the FTC. ${ }^{147}$ In addition, the administration has started using executive orders to mitigate market concentration, including an executive order in July 2021 containing seventy-two provisions designed to boost competition and apply increased scrutiny to mergers. ${ }^{148}$

power in labor markets, and distinguishing between labor as a human capacity and a commodity produced for sale):

Because labor is inseparable from the human mind and body, workers face serious structural disadvantages in bargaining with employers. Workers cannot, for example, control the supply of their fictive commodity. Labor power is produced not strategically for exchange on the market, but nonstrategically according to the biological processes and social customs that shape human reproduction. Nor can workers temporarily remove their labor power from the market, for it perishes each day and must be continuously sustained through the provision of food, shelter, health care, and other necessities. Under ordinary conditions, then, workers experience far greater pressure than employers to reach a deal. The departure of any particular employee will not seriously affect the employer's revenue stream, while the individual worker will lose her entire income. The consequences are immediate and dire for the worker, who needs her paycheck to obtain the basic necessities of life for herself and her dependents, but merely inconvenient for most employers, who can fall back on financial reserves. Compounding these imbalances, the human character of labor imposes severe constraints on its geographic and industrial mobility. While inanimate commodities and capital can be shifted from one location to another without disrupting the lives of their owners, workers must move themselves along with their labor power, abandoning support networks in local communities and associations, and forcing family members either to relocate or accept separation.

Id. at $1555-56$.

145. Steinbaum, supra note 57, at 61-64 (proposing, among other things, to reverse the permissive approach on vertical restraints, which are at the core of fissuring, and to do away with the marketshare-based jurisprudence of the Sherman Act).

146. For the 2016 joint DOJ and FTC Antitrust Guidance for Human Resource Professionals, see Miller \& Baker, supra note 61. For information about criminal charges for employers for wage fixing and no-poaching agreements, see DOJ's First Criminal Charges for Wage-Fixing and No-Poach Labor Agreements: 6 Key Takeaways, LATHAM \& WATKINS (Feb. 18, 2021), https://www.lw.com/ thoughtLeadership/doj-first-criminal-charges-for-wage-fixing-and-no-poach-labor-agreements-6-keytakeaways [https://perma.cc/9AVH-HBRW].

147. See Jim Tankersley \& Cecilia Kang, Biden's Antitrust Team Signals a Big Swing at Corporate Titans, N.Y. TIMES, https://www.nytimes.com/2021/07/24/business/biden-antitrust-amazon-google. html [https://perma.cc/7ETV-5JYF (dark archive)] (Aug. 25, 2021). As mentioned supra note 57, one of the first initiatives of the FTC under the Biden administration has been to consider restrictions to worker noncompetes.

148. See David McCabe \& Jim Tankersley, Biden Urges More Scrutiny of Big Businesses, Such as Tech Giants, N.Y. TIMES, https://www.nytimes.com/2021/07/09/business/biden-big-business-executive- 
Expanding antitrust reach is likely to enjoy public support. Recent polling data on the Big Tech sector suggest that Americans expect such companies to be more heavily regulated if not broken up. ${ }^{149}$ While there seems to be bipartisan momentum for increased regulation of Big Tech, ${ }^{150}$ Democrats in Congress are pushing to reform antitrust regulations as well, again with a particular focus on Big Tech. ${ }^{151}$

It is hard to predict the outcome of all these initiatives (and assessing their merits is frankly beyond the goals of this Article), but the underlying political message that antitrust is no longer taking a hands-off approach is an important signal. ${ }^{152}$

order.html [https://perma.cc/L58Q-AJXN (dark archive)] (Sept. 16, 2021). The House also passed six bills designed to strengthen antitrust regulation and reduce market concentration (the fate of these bills in the Senate is uncertain, despite broad public support for these efforts). See David McCabe \& Steve Lohr, Congress Faces Renewed Pressure To 'Modernize Our Antitrust Laws,' N.Y. TimES (June 29, 2021), https://www.nytimes.com/2021/06/29/technology/facebook-google-antitrust-tech.html [https://perma .cc/7E49-K42G (dark archive)].

149. Eighty-one percent of voters said they are worried about consolidation among Big Tech companies and believe this consolidation harms small businesses and consumers; $89 \%$ of Democrats and $78 \%$ of Republicans strongly or somewhat agree that the government should "rein in" Big Tech. Seventy-four percent of Americans believe the federal government should have greater authority to limit Big Tech corporations' monopoly power, including breaking up the biggest companies. New Poll Shows Bipartisan Majority of Americans Want To Rein In Big Tech, AP NEWs (Oct. 13, 2020), https://apnews.com/press-release/pr-newswire/virus-outbreak-business-legislature-industryregulation-public-opinion-ffa0a276775247a6e645320585fac20c [http://perma.cc/U6VD-97K3].

150. Cat Zakrzewski, Biden Inherits Bipartisan Momentum To Crack Down on Large Tech Companies' Power, WASH. POST (Jan. 18, 2021, 8:00 AM), https://www.washingtonpost.com/politics/2021/01/18/ biden-antitrust-big-tech/ [https://perma.cc/NTR4-DCS4 (dark archive)]; Lauren Feiner, Congress Just Finished Its Big Tech Antitrust Report, Now It's Time To Rewrite the Laws, CNBC (Oct. 7, 2020, 7:49 AM), https://www.cnbc.com/2020/10/07/after-congress-big-tech-antitrust-report-its-time-to-rewrite-thelaws.html [https://perma.cc/S5DR-6S4Q].

151. See, e.g., Proposals To Strengthen the Antitrust Laws and Restore Competition Online: Hearing Before the Subcomm. on Antitrust, Com., \& Admin. L. of the H. Comm. on the Judiciary, 116th Cong. (2020), https://judiciary.house.gov/calendar/eventsingle.aspx?EventID=3367 [https://perma.cc/WSQ 6-Q25L] (describing the "Techlash" that has become the latest wave in antitrust issues, rivaling the breakup of Big Tobacco and Big Oil in previous decades). House Democrats issued a nearly 450-page report that found the tech giants (Amazon, Apple, Facebook, and Google) each hold monopoly power and should be broken up, in some cases. Feiner, supra note 150. In September 2021, Congress held hearings on antitrust reforms and the American worker. See generally Reviving Competition, Part 4: 21st Century Antitrust Reforms and the American Worker: Hearing Before the Subcomm. on Antitrust, Com., \& Admin. L. of the H. Comm. on the Judiciary, 117th Cong. (2021), https://judiciary.house.gov/calendar/ eventsingle.aspx?EventID=4709 [https://perma.cc/7TLN-5YYE].

152. The Biden administration is already seeking to stop consolidation in the publishing industry, as the Justice Department sued to block the $\$ 2.18$ billion acquisition of Simon \& Schuster by Penguin Random House. Press Release, Off. of Pub. Affs., U.S. Dep't of Just., Justice Department Sues To Block Penguin Random House's Acquisition of Rival Publisher Simon \& Schuster (Nov. 2, 2021), https://www.justice.gov/opa/pr/justice-department-sues-block-penguin-random-house-s-acquisitionrival-publisher-simon [https://perma.cc/3352-3R23]. Some authors believe that more active antitrust enforcement has the potential for discouraging further concentration in certain industries: in their view, hesitancy about administering breakups renders antitrust impotent in the face of monopolies, while breakups may increase deterrence. See, e.g., Rory Van Loo, In Defense of Breakups: Administering a Radical 


\section{Strengthening Worker Collective Action}

Because labor market institutions in the United States have historically provided workers with weak protections that have receded over the years, ${ }^{153}$ tweaking them to reboot workers' protections is an avenue that deserves the utmost consideration. In fact, because most of the debate on weaker constituencies revolves around employees, one would expect that policymakers consider employee bargaining protections as one of the first steps of intervention. ${ }^{154}$

Unions are key to employee leverage. When employees choose collective representation, employers must bargain with employees as a group through their collective agent-the union. ${ }^{155} \mathrm{With}$ a collective term-setting process in place, employers cannot individually negotiate terms and conditions of employment, let alone unilaterally set terms subject to market forces. ${ }^{156}$ In other words, unionization ensures that employers cannot benefit from "divide and conquer" strategies and that employees no longer consider their employer to be the only party with the power to set and change wages. ${ }^{157}$ Shifting towards collective action undoubtedly benefits unionized workers, who would be able to capture the so-called union wage premium over their nonunionized counterparts. ${ }^{158}$ In addition, in imperfect labor markets, unions and collective

Remedy, 105 CORNELL L. REV. 1955, 1995-98 (2020) (arguing that hesitancy about administering breakups renders antitrust impotent in the face of monopolies and that breakups may increase deterrence); see also Menesh Patel, Merger Breakups, 2020 WIS. L. REV. 975, 1011 (arguing antitrust agencies should increase the extent of their challenges to previously reviewed and cleared mergers but in a principled way that respects certain significant mitigating factors). For an account of how antitrust is gaining momentum in political circles (especially on worker-related issues), see Eric Posner, Opinion, You Deserve a Bigger Paycheck. Here's How You Might Get It., N.Y. Times (Sept. 23, 2021), https://www.nytimes.com/2021/09/23/opinion/antitrust-workers-employers.html?action=click \&module=RelatedLinks\&pgtype=Article [https://perma.cc/QXS5-6XPD (dark archive)].

153. As described in Section II.A.2, weak labor laws have resulted in a weak union movement. The parallel system of individual rights under employment law has proven ineffective as well.

154. Discussions on workers' rights have remained in the labor field with few spillovers in the corporate law world, aside from the "Fight for $\$ 15$," the vibrant movement in support of increasing the minimum wage and fostering a new union vision. See, e.g., Andrias, supra note 77, at 51-58. However, with national press and politics pushing the issue, a larger discussion in the future may well be in the cards. See Emily Bazelon, Why Are Workers Struggling? Because Labor Law Is Broken, N.Y. TIMES MAG. (Feb. 19, 2020), https://www.nytimes.com/interactive/2020/02/19/magazine/labor-law-unions.html [https://perma.cc/9H8A-Y9VV (dark archive)]; Abigail Johnson Hess, Biden Promises To Be 'the Most Pro-Union President'-and Union Members in Congress Are Optimistic, CNBC (Dec. 2, 2020, 9:15 AM), https://www.cnbc.com/2020/12/01/biden-promises-to-be-the-most-pro-union-president-and-rep.html [https://perma.cc/RF8L-ZFRN].

155. See ESTREICHER \& BODIE, supra note 107, at 4.

156. See id.

157. See BOERI \& VAN OURS, supra note 108, at 63-64; see also Stansbury \& Summers, supra note 6 , at 2 (" $[\mathrm{U}]$ nionization or the threat of union organizing ... enables workers to increase their pay above the level that would prevail in the absence of such bargaining power.").

158. See, e.g., Alison L. BoOTH, THE ECONOMICS OF THE TRADE UNION 169 (1994) (reporting estimates of union wage premiums ranging from $12 \%$ to $20 \%$ in the United States). Union wage 
bargaining help reduce inefficient outcomes by limiting the wage-setting power of monopsonistic employers, which are a dominating force in today's labor markets. ${ }^{159}$ Indeed, greater union power represents a viable counterbalance to structural monopsony, especially when antitrust law is of no avail..$^{160}$

While there are many other aspects of U.S. labor law that can be changed to benefit workers (consider, for instance, bolstering enforcement mechanisms ${ }^{161}$ and moving away from firm-level bargaining), ${ }^{162}$ facilitating unionization remains a crucial threshold issue. In fact, making unionization more achievable so as to ensure greater collective bargaining coverage has historically been key, especially because market forces contributed to reducing density ${ }^{163}$ and the law helped to keep it low. ${ }^{164}$ Rules governing elections of labor representatives do not make it easy for employees who are forced to attend anti-

advantages have been persistent over time. See Farber et al. supra note 79, at 1348 ("[T] he premium remains somewhere between ten and twenty log points over a ninedecade period that saw density (as well as the degree of negative selection by skill) increase and then decrease."); Stansbury \& Summers, supra note 6, at 3 (reporting decreasing wage premiums in the U.S. private sector since the early 1980s).

159. See supra notes $57-61,68-73$ and accompanying text.

160. See generally Suresh Naidu \& Eric A. Posner, Labor Monopsony and the Limits of the Law (Jan. 13, 2019) (unpublished manuscript), https://papers.ssrn.com/sol3/papers.cfm?abstract_id= 3365374 [https://perma.cc/JY99-4ZMR] (arguing that because monopsony power does not necessarily correlate with market concentration, but might depend on other factors such as search frictions and job differentiation, remedies such as empowering unions should be pursued in addition to or in lieu of antitrust remedies). For empirical findings of structural monopsony, Naidu and Posner point to Arindrajit Dube, Alan Manning \& Suresh Naidu, Monopsony and Employer Mis-Optimization Explain Why Wages Bunch at Round Numbers (Nat'l Bureau of Econ. Rsch., Working Paper No. 24991, 2018), https://www.nber.org/papers/w24991 [https://perma.cc/CJ5Y-BLG9]; Arindrajit Dube, Laura Giuliano \& Jonathan Leonard, Fairness and Frictions: The Impact of Unequal Raises on Quit Behavior, 109 AM. ECON. REV. 620 (2019).

161. When employers abandoned long-standing norms and started to test the enforcement mechanism of the NLRA, they soon realized that it made perfect economic sense to collect penalties for breaching the statute rather than absorbing the costs of complying with it. In other words, the enforcement architecture of the NLRA makes it efficient to breach and pay rather than to have the firm unionized. See Jacob S. HACKer \& PAUl Pierson, Winner-TAKe-All Politics: How WASHINGTON MADE THE RICH RICHER-AND TURNED ITS BACK ON THE MidDlE ClasS 129 (2010).

162. Collective bargaining in the United States mostly takes place at the firm level, while in other advanced economies it occurs in a more centralized fashion, such as the sectoral, regional, or national level, thus giving unions a more strategic position. See ESTREICHER \& BODIE, supra note 107, at 9-10.

163. Certain unionized industries became targets of political pressures, liberalization, and competition. As their workers lost jobs, the newly unemployed either changed sectors (moving from construction, transportation, manufacturing, and telecommunication to nonunionized firms operating in services or high-tech) or relocated to nonunionized parts of the country such as the South. See ROSENFELD, supra note 77, at 18-19.

164. See Pope, A Brief History, supra note 77, at 484. 
union meetings ${ }^{165}$ that are normally ridden with misinformation, ${ }^{166}$ while unions do not get response time, ${ }^{167}$ let alone access to the premises. ${ }^{168}$ Moreover, employers have not been shy to make use of all tactics, legal or otherwise, to dissuade employees from joining a union. ${ }^{169}$ In Benjamin Sachs' words, "enabling [the unionization] choice has proven an elusive goal." 170

Eliminating obstacles for workers to express their genuine preference for joining a union should be a top priority for those who care about weaker constituencies. Conceptually, there are three approaches. The most radical one would be to impose a new regime mandating collective bargaining under all circumstances, irrespective of whether workers have elected a bargaining representative. ${ }^{171}$ This would represent a Copernican departure from the current regime that is (or at least purports to be) based on employee choice. A less radical, yet still bold, reform would be to maintain an enabling regime, but

165. See, e.g., RoSENFELD, supra note 77, at 25; Andrias, supra note 77, at 25 (noting that the text of the statute is silent on this issue, and the rule emerged interpretatively); ESTREICHER \& BODIE, supra note 107 , at 121-22.

166. See ESTREICHER \& BODIE, supra note 107, at 120-21 (describing the approach as not entirely persuasive); Brandon Magner, Ten Things Biden's National Labor Relations Board Should Do To JumpStart Industrial Democracy, JACOBIN (Dec. 11, 2020), https://jacobinmag.com/2020/12/biden-nationallabor-relations-board-nlrb [https://perma.cc/N4YQ-46GC] (noting that both the Clinton NLRB and the Obama NLRB declined to intervene and reverse the hands-off approach on false and misleading information that has persisted since the Reagan NLRB).

167. See ESTREICHER \& BODIE, supra note 107, at 120-22.

168. See id.; Andrias, supra note 77, at 25; Cynthia L. Estlund, Labor, Property, and Sovereignty After Lechmere, 46 STAN. L. REV. 305, 311 (1994).

169. Sachs, supra note 83 , at $666-67$ (mentioning legal tactics, such as one-on-one meetings between employees and their supervisors, and illegal ones, such as threatening job losses and firm closures, and discharging union employees); see also Eidelson, supra note 113 (mentioning several tactics to intimidate workers who intend to unionize and asserting that "[g]iven the NLRB's wrist-slap approach to enforcement, firing employees who try to organize a union is one of the most effective short-term investments a company can make").

170. Sachs, supra note 83, at 656 ("[D]esigning a legal regime that protects employees' ability to choose whether they wish to bargain individually or collectively with their employers has been a central and continuing challenge for scholars, Congress, and the National Labor Relations Board (NLRB)."). Employers surely know this pretty well. In fact, they spend millions of dollars every year to (i) prevent their workforce from unionizing under the current law, and (ii) thwart reforms of the NLRB that would make unionizing less cumbersome. See ROSENFELD, supra note 77, at 25-26, 29 ("Employers exploited this power mismatch, simultaneously lobbying lawmakers to refrain from altering labor law while taking advantage of the law's reach and its limits to fight existing unions and fend off unionization attempts."). And, if one looks at the abysmal record of reforming labor law, those dollars are, from an employer's perspective, well spent. See id. at 26 (chronicling the failed attempt to pass the Employee Free Choice Act during the first two years of the Obama presidency and describing more generally the difficulty in passing federal legislation).

171. Note that several other systems do not embrace such an approach. See John Logan, Union Recognition and Collective Bargaining: How Does the United States Compare with Other Democracies?, UC BERKELEY LAB. CTR. (Jan. 1, 2009), https://laborcenter.berkeley.edu/union-recognition-andcollective-bargaining-how-does-the-united-states-compare-with-other-democracies/ [https://perma.cc/FWG7-8V6R]. 
switch the default by requiring a union unless workers vote against it. ${ }^{172}$ If a statutory adoption of unionism (whether a mandatory one or via a default switch) appears politically difficult at least for the time being, a third way to reform would be to amend the process through which workers may depart from the current, nonunion default and opt into unionizing. ${ }^{173}$ Consider, for example, the proposals for alternative systems of union certification such as card check and rapid elections, which were originally contained in the failed Employee Free Choice Act ${ }^{174}$ and are now present in some shape or form in the Protecting the Right to Organize Act ("PRO Act"), the labor reform bill sitting in the Senate. ${ }^{175}$ Under a card check system, an employer would be legally obligated to recognize a union if a majority of workers sign authorization cards solicited by that union in an open process ${ }^{176}$ under a rapid-election system, workers would "vote on unionization almost immediately after an organizing drive has ended,"177 to limit "the amount of time management has to campaign against unionization." ${ }^{\text {178 }}$ Each of these systems represents what Professor Sachs calls an asymmetry-correcting altering rule aimed at mitigating the asymmetric ease of departure from the default, which is currently skewed in favor of employers. ${ }^{179}$ In any event, whilst a crucial gating item, we are mindful that unionization alone is not sufficient to guarantee a rebalancing of power in workers' favor: as noted earlier, employers fight hard, and often successfully, to deny a first contract. $^{180}$

172. For a discussion of various avenues to reform labor law and enhance employee choice by working on the optimal default regime, see Sachs, supra note 83, at 660. As Ian Ayres has pointed out, in the world of private ordering, selecting a default regime versus an opposite one has significant implications over the choice the parties will ultimately make. See generally Ian Ayres, Regulating OptOut: An Economic Theory of Altering Rules, 121 YALE L.J. 2032 (2012) (discussing separate rules governing how private parties can contract around the default legal treatment). For a parallel in the corporate law field, according to Bebchuk and Hamdani, the choice of default should be based on which selection can be reversed more easily by the weaker group. Lucian A. Bebchuk \& Assaf Hamdani, Optimal Defaults for Corporate Law Evolution, 96 Nw. U. L. REV. 489, 502-03 (2002). Under their theory, an efficient opting out is more attainable and likely to occur when directors support it, rather than when they oppose it. Id. Hence, they advocate the choice of a default that in the abstract is more favorable to shareholders than to directors. Id.

173. See Sachs, supra note 83, at 660.

174. Employee Free Choice Act, H.R. 1409, 111th Cong. (2009).

175. See infra notes 199-208 and accompanying text.

176. See Sachs, supra note 83, at 657.

177. Id. at 658 .

178. Id.

179. Id. at 660 (noting that, while "[i]n the abstract, there is no reason to prefer one approach over the other," because of "highly significant pragmatic, political, and institutional reasons," it is more realistic to focus on a new altering rule that deals with the unionization process).

180. Low penalties and the ability to permanently replace striking workers are considered important aids to aggressive tactics deployed by employers. See Eisenbrey, supra note 87 (citing a study by Bronfenbrenner on representation elections conducted between 1999 and 2003, which found that (i) "many of the unions that won representation were never able to bargain a first contract," (ii) "a majority of organized units had no collective bargaining agreement one year after the election," (iii) 
Of course, the desirability of any of the reforms mentioned above (and of any pro-worker reform of labor law, more generally) rests on a normative assessment of the role of unions. There is no shortage of objections over the effects of unions in labor markets, especially from traditional economists, with arguments that are, for the most part, theory based. The main critiques revolve around the wedge of salaries between union and nonunion workers, the increase in wages and reduction of employment in the union sector, and the consequent overflow of workers in the nonunionized sector. ${ }^{181}$ Also, critics lament that consumers would ultimately foot the bill because, with higher labor costs, employers would have no choice but to increase prices or reduce quality. ${ }^{182}$ And in the long run, the equilibrium would not be sustainable because of competition from nonunion firms and from abroad. ${ }^{183}$

Empirical data, however, show that unions do reduce inequality. ${ }^{184}$ The most recent empirical studies confirm that, when unions were strong in the 1950s and 1960s, they acted as a wage compressor and helped contain inequality at a time when membership was vast among non-skilled workers, ${ }^{185}$ and suggest that declining worker power largely explains "sluggish wage growth and a declining labor share of income." 186 In short, as some authors put it, "[ $t]$ he evidence that collective bargaining reduces earnings inequality is overwhelming." ${ }^{187}$ Nevertheless, the main issue raised by union critics has little to do with inequality. Rather, such critics are bothered by the efficiency costs of pro-labor policies in terms of firm profitability and argue that, by raising labor costs, they chill investments and raise unemployment. ${ }^{188}$ In particular, wage premiums are said to contribute to workers' displacement from unionized

"[w]ithin two years, more than one-third still had no contract, and [(iv)] by three years that portion was still around $30 \% ")$.

181. See, e.g., Milton Friedman, CAPITALISM AND FREEDOM 123-25 (1962).

182. James Sherk, The Argument That Most Workers Are Better Off Without Unions, WASH. POST. (Dec. 18, 2014), https://www.washingtonpost.com/news/storyline/wp/2014/12/18/the-argument-thatmost-workers-are-better-off-without-unions/ [https://perma.cc/MQG8-2WU8 (dark archive)].

183. RONALD G. EHRENBERG \& ROBERT S. SMITH, MOdERN LABOR ECONOMICS: THEORY AND PUBLIC POLICY 520-21 (13th ed. 2018).

184. See supra notes $97-104$ and accompanying text.

185. See Farber et al., supra note 79, at 1355 (noting that unions compress the income distribution).

186. Stansbury \& Summers, supra note 6, at abstract, 7 ("[T] he decline of labor rents has also likely increased inequality in labor incomes: the declines in unionization and the real value of the minimum wage, and the fissuring of the workplace, affected middle-and low-income workers more than highincome workers, and some of the lost labor rents for the majority of workers may have been redistributed to high-earning executives (as well as capital owners).").

187. Deakin et al., supra note 77, at 6 (citing Freeman, supra note 101, at 11).

188. See, e.g., Richard A. Epstein, A Common Law for Labor Relations: A Critique of the New Deal Labor Legislation, 92 YALE L.J. 1357, 1385 (1983); Richard A. Epstein, In Defense of the Contract at Will, 51 U. CHI. L. REV. 947, 961 (1984). 
sectors to nonunion sectors, which leads to a deadweight loss, according to some. ${ }^{189}$

Empirical studies do not generally support these claims. In fact, studies have found that changes in union density do not have a significant impact on employment, ${ }^{190}$ and that wage premiums do not reduce output in any significant way. ${ }^{191}$ Also, as unions contribute to less labor turnover, some studies found welfare gains associated with such a reduction equivalent to a $0.2 \%$ to $0.3 \%$ increase in GNP in the United States in the 1980s. ${ }^{192}$ Studies also sometimes offer mixed signals: for example, while some studies show that unions reduce profitability, the most pronounced union effects are found in industries where firms have monopoly power, which "suggests that unions typically share in supernormal profits rather than cutting into normal profits." ${ }^{193}$ Other studies point out that union contracts can maximize efficiency because "there are many workplace decisions where workers have superior information about their cost of doing things." ${ }^{194}$ Similarly, a body of empirical work suggests that worker protections in labor and employment law are positively correlated with productivity and innovation at the firm level, ${ }^{195}$ which is consistent with the

189. See generally Albert Rees, The Effects of Unions on Resource Allocation, 6 J.L. \& ECON. 69 (1963) (noting that the wage structures between union and nonunion sectors lead to unemployment and deadweight losses).

190. See JAUMOTte \& OSORIO Buitron, supra note 79, at 8; Gordon Betcherman, Labor Market Institutions: A Review of the Literature 31 (Pol'y Rsch., Working Paper No. 6276, 2012), https://openknowledge.worldbank.org/bitstream/handle/10986/16382/wps6276.pdf?sequence=1\&isAll owed=y [https://perma.cc/4YQD-R2K2] (reviewing the empirical literature on unions and collective bargaining and noting that, while consensus is far from being reached, it is no longer the case that all labor economists subscribe to the idea that worker protections result in higher unemployment or carry other efficiency costs); David R. Howell, Dean Baker, Andrew Glyn \& John Schmitt, Are Protective Labor Market Institutions at the Root of Unemployment? A Critical Review of the Evidence, 2 CAPITALISM \& SOC'Y 1, 32 (2007); see also TOKE AIDT \& ZAFIRIS TZANNATOS, UNIONS AND COLLECTIVE BARGAINING 63 (2002) (conceding that unions can have an adverse effect on employment yet noting that the "adverse employment effect can be reduced and even reversed if (a) unions and firms bargain over wages and employment and enter an efficient contract or if (b) firms have monopsony power in the absence of collective bargaining").

191. Betcherman, supra note 190, at 15-16 (reviewing a series of studies estimating minimal impact on "long run labor productivity and multi-factor productivity levels").

192. FREEMAN \& MEDOFF, supra note 98 , at 109-10 (estimating the gain to be equivalent to a $1 \%$ to $2 \%$ reduction in costs for unionized firms).

193. AIDT \& TZANNATOS, supra note 190 , at 68 .

194. Suresh Naidu, Worker Collective Action in the 21th Century Labor Market 5 (unpublished manuscript) (citing Elliott Ash, W. Bentley MacLeod \& Suresh Naidu, The Language of Contract: Promises and Power in Union Collective Bargaining Agreements (Mar. 30, 2019) (unpublished manuscript), https://extranet.sioe.org/uploads/sioe2019/ash_macleod_naidu.pdf [https://perma.cc/9WF2-TXNF]), https://www.law.nyu.edu/sites/default/files/Naidu\%20Suresh\%20$\% 20$ Worker\%20Collective\%20Action\%20in\%20the\%2021th\%20Century\%20Labor\%20Market.pdf [https://perma.cc/2T5Y-TLRH] ("A union contract can reallocate these decision rights toward the efficient division, and evidence ... suggests that this reduces labor conflict (measured by strikes).").

195. See Zoe Adams \& Simon Deakin, Corporate Governance and Employment Relations, in THE OXFORD HANDBOOK OF CORPORATE LAW AND GOVERNANCE 1037, 1037-38 (Jeffrey N. Gordon 
view that improving worker treatment makes sense from an efficiency standpoint as better paid workers will provide increased effort. ${ }^{196}$ Finally, as pointed out earlier, unions act as a counterbalance to inherently inefficient equilibriums that would otherwise arise in structurally monopsonistic labor markets. ${ }^{197}$

At this current political moment, bolstering unionization and bargaining rights looks more feasible than in the recent past. Public support for unions is the highest it has been in decades. ${ }^{198}$ The PRO Act has already passed the House $^{199}$ and enjoys the support of President Biden, but faces tough odds in the Senate. ${ }^{200}$ The PRO Act would allow workers to sue employers who illegally thwart unionization efforts (rather than requiring workers to take complaints to the NLRB) and would also add stiffer penalties for companies that retaliate against workers' unionization efforts. ${ }^{201}$ It would ban all so-called "right-towork" laws currently in effect in twenty-seven states, thus restoring significant funding to unions across the country. ${ }^{202}$ The PRO Act would prohibit

\& Wolf-Georg Ringe eds., 2018) (reporting that stricter controls over unfair dismissals are found to be correlated with higher innovation, with causation running from former to the latter, and reduced risk of hold-up by innovative employees). Adams and Deaking report that, after the tightening of wrongful discharge laws in California and Massachusetts, there was an increase in patenting activity, the number of startups, and the number of employees in innovative firms. Id. at 1057.

196. See generally Janet L. Yellen, Efficiency Wage Models of Unemployment, 74 AM. ECON. REV. 200 (1984) (discussing the efficiency-wage model).

197. Farber et al., supra note 79, at 5; see also supra notes 57-61 and 68-73 and accompanying text.

198. According to a recent Gallup poll, $65 \%$ of Americans approve of unions (83\% of registered Democrats, $45 \%$ of registered Republicans, and 64\% of independents). Megan Brenan, At 65\%, Approval of Labor Unions in U.S. Remains High, GALLUP (Sept. 3, 2020), https://news.gallup.com/poll/ 318980/approval-labor-unions-remains-high.aspx [https://perma.cc/FG8M-BG9Z].

199. Protecting the Right to Organize Act, H.R. 2474, 116th Cong. § 2 (2020).

200. Hess, supra note 154 (mentioning that Biden has vowed to be "the most pro-union President"). Although favored by voters, the bill faces long odds in the Senate, where it will have to be approved by all fifty Democrats and, critically, ten Republicans. Gabby Birenbaum, Poll: A Majority of Voters Support the PRO Act, VOX (June 16, 2021, 12:00 PM), https://www.vox.com/2021/6/16/ 22535274/poll-pro-act-unionization-majority-bipartisan [https://perma.cc/73AE-BWRR]. Because of such insurmountable odds, the only reform efforts that, at the time of this writing, might pass are those that can be introduced via the reconciliation process in a spending bill, for which a simple majority in the Senate would be sufficient. Therefore, most of the provisions of the PRO Act will likely not pass anytime soon, as only spending-related legislation is allowed under the reconciliation process. Currently, the provisions that would seem to make the cut under the reconciliation process include increasing penalties for anti-union conduct and moving union elections online, which is something that unions have been pushing for years. Eleanor Mueller, Unions Squeeze Pro-Labor Priorities into Democrats' Spending Bill, POLITICO (Oct. 9, 2021), https://www.politico.com/news/2021/09/21/unionsreconciliation-bill-513423 [https://perma.cc/3D9B-SMK5].

201. See Eli Rosenberg, House Passes Bill To Rewrite Labor Laws and Strengthen Unions, WASH. Post (Feb. 6, 2020), https://www.washingtonpost.com/business/2020/02/06/house-passes-billrewrite-labor-laws-strengthen-unions/ [https://perma.cc/G3G3-JGZW (dark archive)].

202. See Alexia Fernandez Campbell, Democrats Have an Ambitious Plan To Save American Labor Unions, VOX (May 14, 2019), https://www.vox.com/policy-and-politics/2019/5/14/18536789/right-towork-unions-protecting-the-right-to-organize-act-bill [https://perma.cc/JX86-HMQR]. 
employers from permanently replacing striking employees ${ }^{203}$ and would allow federal arbitrators to set the terms of the bargaining agreement if employers do not agree to union demands within thirty days of a request for mediation. ${ }^{204}$ Notably though, the PRO Act would not alter the core of the Wagner Act: workers would still have to win an election to reverse the sticky no-union default under the NLRB. ${ }^{205}$ However, elections would proceed under Obama-era rapidelection procedures ${ }^{206}$ whereby preelection hearings are set for eight days after the union seeks recognition with the NLRB, and employers have a maximum of twenty days to prepare for the preelection hearing and will have no input in the election proceedings. ${ }^{207}$ Finally, and importantly, the PRO Act would permit secondary boycotts, meaning that employees could strike against contractors, vendors, and other businesses in order to exert pressure on the primary employer. ${ }^{208}$

\section{Increasing the Minimum Wage}

Buoying-up wages for the lower tail is a clear way to mitigate inequality. Minimum wage laws set a lower bound to the wage paid to individual workers. First passed by Congress in $1938,{ }^{209}$ when it paid twenty-five cents per hour, the minimum wage system consists of a minimum federal floor, which is currently set at $\$ 7.25$, coupled with the possibility for states to increase it. ${ }^{210}$

Neoclassical economists criticize the minimum wage for its alleged depressive effects on employment: employers may reduce hiring, which can lead to less jobs or work hours for workers. ${ }^{211}$ Notably, their arguments assume that labor markets are competitive. In their model, a minimum wage above the market clearing level would result in the displacement of some workers (because

203. See Robert J. Simandl \& John A. Rubin, Labor Law Reform on the Horizon: Ten Things To Watch Under the PRO Act, NAT'L L. REV. (Feb. 16, 2021), https://www.natlawreview.com/article/laborlaw-reform-horizon-ten-things-to-watch-under-pro-act [https://perma.cc/HZ8V-V974].

204. $I d$.

205. For the analysis of union elections as default reversals, see supra note 172 and accompanying text.

206. See supra notes $174-78$ and accompanying text.

207. Simandl \& Rubin, supra note 203.

208. Id. Currently, employees such as cleaners can boycott the small-scale cleaning contractors who directly employ them but not the building management companies that actually control their wages, as the building management companies are considered to be "neutral" bystanders to the conflict. See supra note 124 and accompanying text.

209. History of Federal Minimum Wage Rates Under the Fair Labor Standards Act, 1938 - 2009, U.S. DEP'T LAB., https://www.dol.gov/agencies/whd/minimum-wage/history/chart [https://perma.cc/SA P8-AGFP] (Oct. 11, 2021).

210. $I d$.

211. See, e.g., Jason Riley, The Minimum Wage's Racially Discriminatory Roots, WALL ST. J. (Feb. 16, 2021, 6:21 PM), https://www.wsj.com/articles/the-minimum-wages-racially-discriminatory-roots11613517678 [https://perma.cc/ZB63-VPKL (dark archive)] (arguing that raising the minimum wage will cost jobs and that Black workers are more likely to lose jobs since they are overrepresented in lowwage positions). 
the higher wage would intersect the downward sloping labor demand curve at a lower quantity level), while some workers who were not on the market at the lower wage would be willing to work at the minimum wage. ${ }^{212}$ The combined effect of worker displacement and new entries in the labor market would result in some unemployment, the theory goes. ${ }^{213}$

However, the discourse is more complex than posited by pure theory, for there exist several factors that can make the impact of the minimum wage on employment more or less severe: how easily labor can be replaced by machinery (or low-skill labor can be replaced by high-skill labor), whether employers can pass labor costs on through prices, and especially the level of monopsony of the underlying labor market. ${ }^{214}$ Indeed, in the presence of an imperfect labor market, the above analysis would change significantly. For instance, if the minimum wage is set between the monopsony wage and the competitive equilibrium, more employment would ensue. True, employer profits would shrink, but if the minimum wage is set at below the marginal labor cost, that would still result in an increase of total surplus and of market efficiency. ${ }^{215}$

Following abundant debate, the preponderance of empirical data on the effects of the minimum wage does not suggest negative employment effects. ${ }^{216}$ Contrary to the predictions of many theorists, the outcome of such debate suggests that the response by labor markets to an increase in minimum wage is quite mellow. ${ }^{217}$ Indeed, studies show either an insignificant impact on

212. See ARINDRAJIT DUBE, IMPACTS OF MINIMUM WAGES: REVIEW OF THE INTERNATIONAL EVIDENCE 19 (2019), https://assets.publishing.service.gov.uk/government/uploads/system/uploads/ attachment_data/file/844350/impacts_of_minimum_wages_review_of_the_international_evidence_Ar indrajit_Dube_web.pdf [https://perma.cc/FW3A-RGBG] ("In the standard model of supply and demand, competition between employers ensures that wages are equal to the 'value marginal product of labour' - the value of what a worker contributes to the employer's production. It is also assumed that this marginal product is diminishing in the number of workers hired; holding all other inputs like machinery and materials constant, additional workers will make smaller economic contributions. This diminishing marginal product leads to a downward sloping demand curve for labour. Market wages are set where this demand meets the supply of workers. In such an environment, a government mandated wage standard above the market wage will produce some job loss.”).

213. For a summary, see BOERI \& VAN OURS, supra note 108, at 39.

214. See DUBE, supra note 212, at 20-21.

215. See BOERI \& VAN OURS, supra note 108, at 36 (describing additional scenarios: (a) if the minimum wage is set above the competitive equilibrium, the labor demand determines the relationship between minimum wage and employment, and (b) if the minimum wage is set above the marginal labor cost, employment would drop to lower levels than under the monopsony equilibrium).

216. See generally DUBE, supra note 212 (arguing that minimum wage does not always correlate with negative employment effects, such as unemployment).

217. See JAUMOTTE \& OSORIO BuItRon, supra note 79, at 8; Betcherman, supra note 190 (reviewing the empirical literature on minimum wage and noting that, while consensus is far from being reached, it is no longer the case that all labor economists subscribe to the idea that worker protections result in higher unemployment or carry other efficiency costs); ORG. FOR ECON. COOP. \& Dev. (OECD), OECD EMPLOYMEnT OutLOOK: BoOsting JOBS AND INCOMES 175 (2006), https://read.oecd-ilibrary.org/employment/oecd-employment-outlook-2006_empl_outlook-2006- 
employment or a modestly negative impact, with some studies showing a positive employment effect. ${ }^{218}$ In particular, the data suggest that, among states that have recently raised the minimum wage, there have not been employment reductions or other economic harms. ${ }^{219}$ Moreover, one recent study found that minimum wage effects on employment become less negative as concentration increases, and even become positive in the most concentrated labor markets: "[f]rom a policy perspective, our findings suggest that the potential employment costs of a minimum wage policy are reduced when monopsony power is pervasive, while the benefits are especially great (because monopsony already depresses wages below the competitive level)." 220 Understandably, empirical studies caution that their results are limited to the increases in the minimum wage they actually observe: larger increases might result in different

en\#page1 [https://perma.cc/4Q7J-B6RW] (finding no link between changes in minimum wage and employment levels); Howell et al., supra note 190, at 51 (2007).

218. David Card and Alan Krueger published a famous study in the mid-1990s showing that the minimum wage has an insignificant effect on employment. David Card \& Alan Krueger, Time-Series Minimum-Wage Studies: A Meta-Analysis, 85 AM. ECON. REV. 238, 238 (1995). The authors compared adjoining local areas in New Jersey and Pennsylvania with different minimum wages around the time of a policy change. See id. (reporting data showing that the minimum wage has an insignificant effect on employment and suggesting that "specification searching and publication biases" led to data errors in earlier studies that showed a correlation between unemployment and a minimum wage). However, the study was subsequently criticized. David Neumark \& William Wascher, Minimum Wages and Employment: A Case Study of the Fast-Food Industry in New Jersey and Pennsylvania: Comment, 90 AM. ECON. REV. 1362, 1362-63 (2000) (running the same experiment as Card and Krueger but using payroll data instead of phone interviews and concluding that the New Jersey increase in the minimum wage resulted in a decrease in employment). A 1998 survey of labor economists showed respondents evenly split on the question of whether the minimum wage should be increased. Victor Fuchs, Alan Krueger \& James Porterba, Economists' Views About Parameters, Values, and Policies: Survey Results in Labor and Public Economics, 36 J. ECON. LITERATURE 1387, 1390. The more recent studies confirm the findings in Card and Krueger's seminal study. See Arindrajit Dube, T. William Lester \& Michael Reich, Minimum Wage Effects Across State Borders: Estimates Using Contiguous Counties, 92 REV. ECON. \& STAT. 945, 945 (2010) (looking at local differences in minimum wages throughout the entire United States over more than sixteen years and finding strong earning effects and no employment effects of minimum wage increases); Jonathan Meer \& Jeremy West, Effects of the Minimum Wage on Employment Dynamics, 51 J. HUM. RES. 500, 501 (2016); Doruk Cengiz, Arindrajit Dube, Attila Lindner \& Ben Zipperer, The Effect of Minimum Wages on Low-Wage Jobs, 134 Q.J. ECON. 1405, 1405 (2019).

219. For example, a study by researchers at the New York Fed found "no discernible effect on employment." Jason Bram, Fatih Karahan \& Brendan Moore, Minimum Wage Impacts Along the New York-Pennsylvania Border, LiBERTY ST. ECON., FED. RSRV. BANK N.Y. (Sept. 25, 2019), https://libertystreeteconomics.newyorkfed.org/2019/09/minimum-wage-impacts-along-the-new-yorkpennsylvania-border.html [https://perma.cc/3VLJ-NNYF]. One study found no evidence of job reduction or any adverse impact on employment and also found some spillover effect raising wages beyond the minimum wage. See Cengiz et al., supra note 218, at 1451.

220. See Jose Azar, Emiliano Huet-Vaughn, Ioana Marinescu, Bledi Taska \& Till von Wachter, Minimum Wage Employment Effects and Labor Market Concentration 19 (July 10, 2019) (unpublished manuscript), https://ssrn.com/abstract=3416016 [https://perma.cc/847R-2ZK5]. For a discussion on monopsony and the decrease of the labor share, see supra notes 57-61 and 68-73 and accompanying text. 
employment effects. ${ }^{221}$ According to a recent report by the Congressional Budget Office, raising the federal minimum wage to $\$ 15$ per hour, as current proposals purport to accomplish, would increase the deficit by $\$ 54$ billion over ten years and would cost 1.4 million jobs. ${ }^{222}$ However, the policy would lift 900,000 people out of poverty and raise income for seventeen million people, or one in ten workers. ${ }^{223}$ The net increase for workers would be $\$ 333$ billionmore than double the amount lost from workers who lose jobs. ${ }^{224}$ So even if a minimum wage increase might result in some employment loss, such a loss is expected to be outweighed by its potential benefits, which are not limited to higher earnings for lower-income workers, but extend to a reduction in public benefits, as well as an increase in what workers and society perceive as fair pay. ${ }^{225}$

Increasing the federal minimum wage has substantial public support, with two-thirds of Americans favoring raising it to $\$ 15$ an hour. ${ }^{226}$ This support is due in part to the success of the "Fight for $\$ 15$ " movement, a national grassroots campaign begun in 2012 by fast-food workers, which has gained significant momentum over the last few years. ${ }^{227}$ An increase to $\$ 15$ is a priority of President Biden's economic agenda, even though currently minimum wage legislation has stalled due to a temporary agreement among legislators to bar a minimum wage increase for the duration of the pandemic. ${ }^{228}$ At the state and local level, minimum wage laws have already been strengthened: Connecticut, California, Illinois, Maryland, Massachusetts, New Jersey, New York, and D.C. have all enacted legislation requiring a minimum wage of $\$ 15$ to be phased in by 2025 or earlier. ${ }^{229}$ Moreover, several corporations have already raised their

221. Dube et al., supra note 218, at 962

222. Eli Rosenberg, CBO Report Finds \$15 Minimum Wage Would Cost Jobs but Lower Poverty Levels, WASH. POST (Feb. 8, 2021, 1:55 PM), https://www.washingtonpost.com/business/2021/ 02/08/minimum-wage-hike-15-an-hour-by-2025-would-result-14-million-unemployed-nonpartisancongressional-budget-office-says/ [https://perma.cc/5PXG-NY2B (dark archive)].

223. Id.

224. Id.

225. See DuBE, supra note 212, at 2-3. See generally Ernst Fehr, Lorenz Goette \& Christian Zehnder, A Behavioral Account of the Labor Market: The Role of Fairness Concerns, 1 ANN. REV. ECON. 355 (2009) (showing that preference for fairness is strong as citizens are willing to sacrifice some of their personal payoff to fight off perceived injustices).

226. Leslie Davis \& Hannah Hartig, Two-Thirds of Americans Favor Raising Minimum Wage to $\$ 15$ an Hour, PEW RSCH. CTR. (July 30, 2019), https:/www.pewresearch.org/fact-tank/2019/07/30/twothirds-of-americans-favor-raising-federal-minimum-wage-to-15-an-hour/ [https://perma.cc/TR6W-V GSY].

227. Andrias, supra note 77, at 47-48.

228. Luke Broadwater, Haley Fuchs \& Jim Tankersley, Senate Backs Biden's Stimulus, but Rejects Quick Minimum Wage Increase, N.Y. TIMES (Mar. 6, 2021), https://www.nytimes.com/2021/02/04/us/ politics/biden-stimulus-senate-vote.html [https://perma.cc/V4F6-4TCX (dark archive)].

229. Chris Marr, States with \$15 Minimum Wage Laws Doubled This Year, BloOMBERG L. (May 23, 2019, 4:17 AM), https://news.bloomberglaw.com/daily-labor-report/states-with-15-minimum-wagelaws-doubled-this-year [https://perma.cc/V4F6-4TCX]. 
minimum wage: Amazon, Target, JPMorgan Chase, Facebook, Wells Fargo, Costco, Spectrum, and Ben \& Jerry's all raised their minimum wage to $\$ 15$ an hour, while Bank of America raised its minimum wage to $\$ 17$ an hour. ${ }^{230}$ Walmart, on the other hand, the nation's largest employer, still maintains a minimum wage of only $\$ 11$, though it has recently agreed to a raise to $\$ 15$ an hour for half of its employees. ${ }^{231}$

In closing, upping the federal minimum wage is a change that can benefit workers, and one that is not likely to happen at the federal level without direct regulation. In the meantime, some companies are raising the minimum wage due to public pressure, not due to any corporate governance changes.

\section{Empowering Outsourced Labor and Gig Workers}

Gig workers and other types of outsourced labor do not benefit from the protections they would receive if treated as employees: health and safety standards are laxer, ${ }^{232}$ wage determination is detached from the risk of future unionization, ${ }^{233}$ minimum wage laws are either another employer's issue (if the work is outsourced) or a nonissue (when the gig worker is an independent contractor), ${ }^{234}$ and so on. Escaping from all such laws is in fact one of the main drivers behind business models of online platforms and other fissured employers. $^{235}$

Some states already address the problem, and, at the national level, a few legislative proposals are on the table to remedy the situation: the preferred solution is to require that these workers be properly classified as employees. Massachusetts, New Hampshire, and Indiana, for example, have laws that create a presumption that a worker is an employee and shift the burden on the employer to show that the worker is not an employee. ${ }^{236}$ One federal bill

230. Courtney Connley, Amazon, Facebook, and 8 Other Companies that Have Committed to Raising Their Minimum Wage to $\$ 15$ an Hour, CNBC (May 25, 2019, 9:30 AM), https://www.cnbc.com/2019 105/24/glassdoor-10-companies-that-have-committed-to-raising-minimum-wage.html [https://perma. cc/5FTJ-TZDC]. One recent study found positive spillover effects of wage increases at these employers, estimating that Amazon's wage increase of $10 \%$ led to an average wage increase of $2.6 \%$ among employers in the same commuting zone. Ellora Deroncourt, Clemens Noelke \& David Weil, Spillover Effects from Voluntary Employer Minimum Wages 1 (Feb. 28, 2021) (unpublished manuscript), https://papers.ssrn.com/sol3/papers.cfm?abstract_id=3793677 [https://perma.cc/4BRP5HS2].

231. Nathaniel Meyersohn, Walmart Just Boosted Pay to \$15. It's Not What You Think, CNN (Feb. 18, 2021, 10:38 AM), https://www.cnn.com/2021/02/18/investing/207almart-minimum-wage-retail/ index.html [https://perma.cc/BR77-76CS].

232. See, e.g., Molly Tran \& Rosemary Sokas, The Gig Economy and Contingent Work, 59 J. OCCUPATIONAL \& ENV'T MED. e63, e63 (2017).

233. See WEIL, FISSURED WORKPLACE, supra note 86, at 77.

234. See id. at 77, 87-88.

235. See Steinbaum, supra note 57 , at 46.

236. WEIL, FISSURED WORKPLACE, supra note 86, at 204-05. Another possible approach, taken by West Virginia with respect to the coal industry, is to require any company that "benefited from a 
proposed in the past was the Employee Misclassification Prevention Act, which would have required record-keeping and notice requirements for employers who classify workers as independent contractors, and violations of the law would have carried significant penalties. ${ }^{237}$ The most current proposal regarding worker misclassification is the PRO Act, which is sitting in the U.S. Senate and would require most gig workers, including those employed by Uber, Lyft, and Doordash, to be classified as employees. ${ }^{238}$

Such a measure takes its cue from the California law that was axed with Proposition 22 ("Prop 22"). ${ }^{239}$ In 2019, the treatment of gig workers rose to such prominence that the California legislature passed a bill forcing ride-hailing companies and delivery start-ups to classify their gig workers as employees. ${ }^{240}$ The bill, referred to as AB5, codified and expanded a California Supreme Court ruling that a person providing labor or services must be classified as an employee unless they are (i) "free from control and direction" of their employer, (ii) performing work "outside the usual course of the hiring entity's business," and (iii) "customarily engaged in an independently established trade, occupation, or business of the same nature as that involved in the work performed." ${ }^{241}$ Uber and Lyft refused to comply with the law, prompting a suit from the state attorney general. ${ }^{242}$ Despite a court order to hire drivers as employees, the companies still did not comply and instead threatened to shut down rather than hire their drivers. ${ }^{243}$ Meanwhile, Uber, Lyft, and other gig worker companies, including delivery start-ups, mounted a successful \$200 million campaign to convince Californians to support a ballot measure, Prop 22, which overturned the law. ${ }^{244}$ Drivers and other gig workers reported decreased pay in the wake of Prop 22. ${ }^{245}$

Despite the result in California, there remains substantial political and public support for the extension of employee rights and benefits to gig workers. According to one recent poll, a majority of Americans-62\% (including 59\% of

\footnotetext{
mining operation [to] be held responsible for paying wages for work that led to that benefit" and will also be civilly liable to employees that conducted this work, for the payment of wages and benefits. Id. at 204 .

237. Employee Misclassification Prevention Act, H.R. 3718, 112th Cong. (2011).

238. See Protecting the Right to Organize Act, H.R. 2474, 116th Cong. § 2 (2020).

239. See infra notes $244-45$ and accompanying text.

240. Assemb. B. 5, 2019-2020 Leg., Reg. Sess. (Cal. 2019); see Dynamex Operations W. v. Superior Ct., 416 P.3d 1, 4-5 (Cal. 2018).

241. Dynamex Operations $W ., 416$ P.3d at 35 .

242. Kate Conger, Uber and Lyft Drivers in California Will Remain Contractors, N.Y. TimES (Nov. 4, 2020), https://www.nytimes.com/2020/11/04/technology/california-uber-lyft-prop-22.html [https:// perma.cc/F2MX-XEC4 (dark archive)] [hereinafter Conger, Remain Contractors].

243. Id.

244. Id.

245. Michael Sainato, "I Can't Keep Doing This": Gig Workers Say Pay Has Fallen After California's Prop 22, GUARDiAn (Feb. 18, 2021, 5:00 AM), https://www.theguardian.com/us-news/2021/feb/18/ uber-lyft-doordash-prop-22-drivers-california [https://perma.cc/UA3S-43CK].
} 
Republicans)-supported giving gig workers the same job protections as employees. ${ }^{246} \mathrm{Gig}$ worker protections such as this would meaningfully shift power and resources to workers, and again is more likely to come about by direct regulation than by any change to corporate governance.

\section{STAKEHOLDERISM VS. DIRECT REGULATION}

In Part II, we identified areas of reform that would address some of the main root causes of the decline in workers' power. While antitrust initiatives strive to avoid further weakening of workers as a result of concentration, certain labor measures that work from the bottom up have the capacity to shift power and resources to them. We have surveyed such proposals to put them in contrast with the stakeholderist claim that would instead privilege a top-down change from within and at the top of corporate power-the boardroom. Such contrast is necessary because stakeholderism cannot be evaluated in a vacuum, but its benefits and flaws must be compared against alternative proposals, including the policies surveyed in Part II, as benchmarks.

To that end, this part reframes the analysis of such reforms in the context of the debate on stakeholderism by exploring whether stakeholderism offers more feasible alternatives to these regulatory measures and whether stakeholderism can attain goals similar to such reforms and/or can help pave the way to achieving them. To understand whether stakeholderism can offer any advantage, in Section III.A we first review certain prevailing trends and practices of how corporations generally deal with requests and campaigns by the workforce. In Section III.B, we then evaluate whether and to what degree, if any, stakeholderism can improve the position of workers. We conclude that stakeholderism is more likely to hinder better protections for workers and weaker constituencies in general.

\section{A. How Corporations Deal with Requests from the Workforce}

In a previous work, we suggested that corporations would be quite happy to ride on the stakeholderist train for their own private benefit. ${ }^{247}$ Stakeholderism would provide businesses the pretext to resist reform initiatives by claiming that, thanks to directors' newly broadened agendas, weaker constituencies will be better protected privately rather than via external reform. ${ }^{248}$ For instance, corporations may disclaim the need for certain policy changes on several grounds, such as that one size does not fit all, that more

246. Linda Hamilton Krieger, Data For Progress, Just. Collaborative Inst., The Gig IS UP: CORONAVIRUS PULLS BACK THE CURTAIN ON THE INDEPENDENT CONTRACTOR EPIDEMIC 2 (2020), https://www.filesforprogress.org/memos/the_gig_is_up.pdf [https://perma.cc/ U4D6-9ETU].

247. Gatti \& Ondersma, supra note 7, at 9-10.

248. See id. at 68-69. 
protections towards workers would make labor markets more rigid, and that they are in the best position to determine the changes that make sense for their business. We have labeled this as the defensive feature of stakeholderismproviding a platform to systematically object to reform. ${ }^{249} \mathrm{We}$ also noted that corporations may well wield stakeholderism offensively; once there are more constituencies to look out for, directors can justify advocating for a variety of reforms (including those furthering more insulation from investor pressure ${ }^{250}$ ) to nominally protect weaker constituencies but, in reality, serve their selfinterest. ${ }^{251}$

Below, we illustrate certain patterns of corporate behavior, including political engagement, when facing labor requests. First, in Section III.A.1 we observe that corporations tend to disguise their interests when lobbying, thereby retaining and expanding their share of influence and resources while seeming disinterested. Then, in Section III.A.2 we offer some evidence of how corporations deploy a variety of methods to confront, contrast, and ultimately thwart requests from the workforce.

\section{The Opacities of Corporate Lobbying}

It is no secret that corporations deploy considerable expenditures each year to protect and advance their interests. ${ }^{252}$ Fortune 100 companies spent $\$ 2$ billion on lobbying efforts between 2014 and 2017, the U.S. Chamber of Commerce spent nearly $\$ 82$ million in the first nine months of 2020 (and over $\$ 77$ million in 2019), and the Business Roundtable spent around $\$ 17$ million in the first nine months of 2020 (and almost $\$ 20$ million in 2019). ${ }^{253}$ Indeed, the data show that corporations sometimes lobby directly, and other times indirectly ${ }^{254}$ via

249. See id. at 10, 67-69.

250. Roe, America's CEOs, supra note 36 ("[A]ctivist shareholders are making life uncomfortable for the boards and senior executives of America's largest corporations. The Business Roundtable's statement is thus, in part a plea from CEOs for more autonomy vis-à-vis shareholders.").

251. See Gatti \& Ondersma, supra note 7, at 9-10, 64-67.

252. Corporations and trade associations spend over $84 \%$ of federal lobbying expenditures and $86 \%$ of state government lobbying expenditures. See John M. de Figueiredo \& Brian Kelleher Richter, Advancing the Empirical Research on Lobbying, 17 ANN. REV. POL. SCI. 163, 165 (2014); see also ADAM ANDRZEJEWSKI \& THOMAS W. SMITH, FEDERAL Funding OF FORTUNE 100 COMPANIES, OPENTHEBOOKS.COM (2019), https://www.openthebooks.com/assets/1/6/Oversight_ Report_-_Fortune_100_FINAL.pdf [https://perma.cc/UM9P-MU5X].

253. See US Chamber of Commerce, OPEN SECRETS, https://www.opensecrets.org/orgs/uschamber-of-commerce/summary?id=D000019798 [https://perma.cc/3YCN-7727]; Client Profile: Business Roundtable, OPEN SECRETS, https://www.opensecrets.org/federal-lobbying/clients/summary ?cycle=2019\&id=D000032202 [https://perma.cc/6HZL-DWSU].

254. de Figueiredo \& Richter, supra note 252, at 165 (noting that large corporations are far more represented in these lobbying efforts than small business interests, with the latter typically using trade associations). See generally John M. de Figueiredo, The Timing, Intensity, and Composition of Interest Group Lobbying: An Analysis of Structural Policy Windows in the States (Nat'l Bureau of Econ. Rsch., Working Paper No. 10588, 2014), https://scholarship.law.duke.edu/faculty_scholarship/2483/ [https://perma. cc/8663-4Y99] (examining the timing of interest group lobbying and introducing a framework based 
intermediaries such as the U.S. Chamber of Commerce and the Business Roundtable $^{255}$ (corporations' representatives sit on the boards of these organizations). ${ }^{256}$ In the latter case, most of the spending is opaque to investors and the public: Lucian Bebchuk and Rob Jackson have noted that "corporations contribute to entities that spend significant sums on politics, yet these intermediaries do not have to disclose either the identity of the corporations that make these contributions or the amounts that they contribute." ${ }^{257}$ The

on recurring "structural policy windows"); Micky Tripathi, Stephen Ansolabehere \& James M. Snyder, Are PAC Contributions and Lobbying Linked?, 4 BUS. POL. 131 (2002) (finding a strong connection between lobbying and campaign contributions); Wendy L. Hansen, Neil J. Mitchell \& Jeffrey M. Drope, Collective Action, Pluralism, and the Legitimacy Tariff: Corporate Activity or Inactivity in Politics, 57 POL. RSCH. Q. 421 (2004) (exploring a wide range of activities that corporation and trade organizations participate in to better understand their political activity); Bing Guo, Lobby or Contribute? The Impact of Corporate Governance on Firms' Political Strategies (Oct. 27. 2009) (unpublished manuscript), https://papers.ssrn.com/sol3/papers.cfm?abstract_id=1495143 [https://perma.cc/9KVNZ84B] (studying the impact of corporate governance levels on corporate lobbying and political contributions); Yael V. Hochberg, Paola Sapienza \& Annette Vissing-Jørgensen, A Lobbying Approach to Evaluating the Sarbanes-Oxley Act of 2002, 47 J. ACCT. RSCH. 519 (2009) (studying the lobbying behavior of investors, corporations and business groups and how it impacted the Sarbanes-Oxley Act); Matthew D. Hill, G. Wayne Kelly, G. Brandon Lockhart \& Robert A. Van Ness, Determinants and Effects of Corporate Lobbying, 42 FIN. MGMT. 931 (2013) (finding that corporate managers utilize lobbying and campaign contribution channels to influence politics); Brian K. Richter, Krislert Samphantharak \& Jeffrey F. Timmons, Lobbying and Taxes, 53 AM. J. POL. SCI. 893 (2009) (exploring the tax benefits that U.S. firms obtained from lobbying). To the extent that smaller groups and businesses do lobby, they do so primarily through trade associations rather than lobbying on their own behalf. See generally William R. Kerr, William F. Lincoln \& Prachi Mishra, The Dynamics of Firm Lobbying, 6 AM. ECON. J. 343 (2014) (discussing the impact of firm size on lobbying); Marianne Bertrand, Matilde Bombardini \& Francesco Trebbi, Is It Whom You Know or What You Know? An Empirical Assessment of the Lobbying Process, 104 AM. ECON. REV. 3885 (2014) (suggesting various reasons for this pattern, including fewer resources to devote to lobbying and lack of sufficient access to politicians).

255. The top spenders on lobbying are, in order, the U.S. Chamber of Commerce (nearly $\$ 82$ million in the first nine months of 2020), the National Association of Realtors (about \$84.1 million), the Pharmaceutical Research \& Manufacturers of America (\$29.5 million), the American Hospital Association ( $\$ 24.3$ million), Blue Cross Blue Shield (\$23.6 million), the American Medical Association (\$19.3 million), Facebook (\$19.7 million), Amazon (\$18.7 million), and the Business Roundtable (around \$17 million). Top Spenders, OPEN SECRETS, https://www.opensecrets.org/federal-lobbying/ top-spenders [https://perma.cc/BBT5-45FV]. Defense contractors Boeing, Northrop Grumman, Raytheon, and Lockheed Martin each spent around \$12 million. Id. Comcast spent \$14.4 million; the NCTA Internet and Television Association spent $\$ 15.5$ million. Id. The Biotechnology Innovation Organization spent $\$ 12.6$ million, and the American Chemistry Council spent $\$ 14$ million. Id. The American Bankers Association spent $\$ 11.8$ million. Id. In one study, industry intermediaries such as these spent over $\$ 1.5$ billion in a six-year period. See Lucian A. Bebchuk \& Robert Jackson, Shining Light on Corporate Political Spending, 101 GEO. L.J. 923, 931 (2013) [hereinafter Bebchuk \& Jackson, Shining Light]. In 2012, interest groups spent $\$ 3.5$ billion to lobby the federal government, several times more than the roughly $\$ 750$ million that interest groups and PACs (including super PACs) were spending annually on campaign contributions at the time. de Figueiredo \& Richter, supra note 252, at 165.

256. Bebchuk \& Jackson, Shining Light, supra note 255, at 932-33.

257. Id. at 930 ("[T] here is no information in the public domain on how much of an intermediary's funds, if any, was provided by a given public company."); see id. at 923 (presenting "empirical evidence 
Chamber of Commerce does not disclose the identities of its donors. ${ }^{258} \mathrm{We}$ do know, however, that more than half of the Chamber's funding comes from just 74 donors who gave over $\$ 500,000$, and that $96 \%$ of the Chamber's funding is from 1,500 donors giving at least $\$ 5,000 .{ }^{259}$

Far from being a new phenomenon, corporate money in U.S. politics simply reached an accelerated speed in the wake of the controversial Citizens United decision. ${ }^{260}$ Not only has spending increased since then, ${ }^{261}$ but

indicating that a substantial amount of corporate spending on politics occurs under investors' radar screens"); see also Caroline Crenshaw \& Michael Porter, Transparency and the Future of Corporate Political Spending, HARV. L. SCH. F. ON CORP. GOvERNANCE (Mar. 15, 2021), https://corpgov.law.harvard. edu/2021/03/15/transparency-and-the-future-of-corporate-political-spending/ [https://perma.cc/8ST] -BYWP] (discussing the persistence of undisclosed "socially destructive lobbying" and the need for corporate disclosure of political spending); Lucian A. Bebchuk \& Robert Jackson, Corporate Political Speech: Who Decides?, 124 HARV. L. REV. 83, 93 (2010) (discussing empirical evidence that corporations spend nontrivial corporate resources on political lobbying). As to whether lobbying benefits or harms investors, compare John C. Coates IV, Corporate Politics, Governance, and Value Before and After Citizens United, 9 J. EMP. LEGAL STUD. 657, 658 (2012) ("In the majority of industries (e.g., apparel, retail, equipment), political activity is common but varied, and it correlates negatively with measures of shareholder power (shareholder concentration and shareholder rights), positively with signs of managerial agency costs (corporate jet use by CEOs), and negatively with shareholder value ...."), with Thomas Stratmann \& J.W. Verret, How Does Corporate Political Activity Allowed by Citizens United v. Federal Election Commission Affect Shareholder Wealth?, 58 J.L. \& ECON. 545, 545 (2015) ("Our findings show that corporate political activity enhances shareholder wealth, particularly in firms that are small to medium sized, firms that spend relatively less on lobbying, and firms operating in more heavily regulated industries.").

258. Dan Dudis, Pub. Citizen, The Chamber of Secrets: An Investigation into Who FundS THE NOTORIOUSLY OPAQUE U.S. CHAMBER OF COMMERCE 3 (2017), https:// chamberofcommercewatch.org/wp-content/uploads/2017/09/Chamber_of_Secrets_members_report. pdf [https://perma.cc/PC5P-ZRBM].

259. Id. at 4

260. See Citizens United v. Fed. Election Comm'n, 558 U.S. 310, 336-66 (2010) (prohibiting the government from restricting independent expenditures for political communications by corporations, including nonprofit corporations, labor unions, and other associations). Essentially, corporations and businesses entities can engage in unlimited political spending, so long as such spending is independent of a party or a candidate. Id.

261. In the five years after Citizens United, super PACs, corporations, labor unions, and other outside groups spent almost $\$ 2$ billion on federal elections - two and a half times more than in the years preceding Citizens United. See DANIEL I. WEINER, BRENNAN CTR. FOR JUST., Citizens UNITED FIVE YEARS LATER 4 (2015), https://www.brennancenter.org/sites/default/files/2019-08/ Report_Citizens_United_\%205_\%20Years_\%20Later.pdf [https://perma.cc/3LXQ-MLKX] (noting that spending on presidential elections tripled between the 2008 and 2012 elections, more than quadrupled between the 2006 and 2010 midterms, and doubled again between the 2010 and 2014 midterms, while statewide and local races have been affected as well). Dark money in Senate elections more than doubled between 2010 and 2014, from \$105 million to \$226 million in inflation-adjusted dollars. IAN VANDERWALKER, BRENNAN CTR. FOR JUST., ELECTION SPENDING IN 2014: OUTSIDE SPENDING IN SENATE RACES SINCE CITIZENS UNITED 2 (2015), https://www.brennancenter.org/ sites/default/files/analysis/Outside\%20Spending\%20Since\%20Citizens\%20United.pdf [https://perma. cc/B9U4-WP5E]. 
corporations have also lobbied heavily to prevent any rule that would require them to disclose how much they spend on political campaigns. ${ }^{262}$

Lobbying expenditures are directed overwhelmingly to conservative candidates and committees. ${ }^{263}$ For instance, the lobbying activity of the U.S. Chamber of Commerce has included opposing minimum wage increases; labor and employment provisions of bills designed to enhance family and medical leave; bills designed to protect pregnant women from discrimination; occupational safety and health rights; the Fairness in Labor Litigation Act; A Living Wage, Jobs for All Act; the Truth in Employment Act; the Violence Against Women Reauthorization Act; and a variety of acts related to union organizing. ${ }^{264}$ Even smaller organizations - such as the American Legislative Exchange Council ("ALEC"), which presents itself as a public interest nonprofit-raise money from corporations and conservative foundations. ${ }^{265}$ ALEC drafts and lobbies for pro-business state-level positions related to issues such as tort reform, minimum wage, right-to-work bills, tax cuts, and pension overhauls. ${ }^{266}$ Hence, in many cases, several corporations currently professing to support progressive causes such as climate change mitigation, voting rights, and

262. See Luigi Zingales, Corporations Fight Push for Donation Disclosure, GulF TiMES (June 3, 2013, 11:24 PM), https://www.gulf-times.com/story/355016/Corporations-fight-push-for-donationdisclosure [https://perma.cc/G24M-3USK]; Lucian A. Bebchuk, Robert J. Jackson Jr., James D. Nelson \& Roberto Tallarita, The Untenable Case for Keeping Investors in the Dark, 10 HARV. BUS. L. REV. 1, 34 (2020); Cydney Posner, Is It Time for Corporate Political Spending Disclosure?, HARV. L. SCH. F. ON CORP. GOVERNANCE (Mar. 17, 2019), https://corpgov.law.harvard.edu/2019/03/17/is-it-time-forcorporate-political-spending-disclosure/ [https://perma.cc/VP2K-5UX2].

263. See, e.g., Bruce Freed, Karl SANDStrom, Peter Hardin, Dan Carroll, Carlos Holguin \& ANDrew Feldman, CONFlicted COnSEQuences, Ctr. FOR Pol. ACCOUNTABILITY 1, 5 (2021), https://politicalaccountability.net/reports/cpa-reports/conflictedconsequences [https://perma.cc/ZFY9-HYDT]; see also ALEXANDER HERTEL-FERNANDEZ, POLITICS AT WORK: HOW COMPANIES TURN THEIR WORKERS INTO LOBbYISTS 118 (2018) ("Leading companies and business associations had ... started to hold captive audience meetings about a broader range of political issues, including some related to political candidates, in the early 2000s, as Walmart did in attempt to discourage votes for political candidates who supported expanding union organizing rights.").

264. For reference, the full list is published as a Lobbying Report as required by the Lobbying Disclosure Act of 1995, and the data are made available on the U.S. Senate website. See Downloadable Lobbying Databases, U.S. SENATE, https://www.senate.gov/legislative/Public_Disclosure/database_ download.htm [https://perma.cc/7YBS-YF6U]; see also James Kwak, Corporate Law Constraints on Political Spending, 18 N.C. BANKING INST. 251, 252-53 (2013).

265. Andrew Prokop, How ALEC Helps Conservatives and Businesses Turn State Election Wins into New Laws, VOX, https://www.vox.com/2014/11/17/7186057/american-legislative-exchange-council [https://perma.cc/FHV8-MXFF (staff-uploaded archive)] (Mar. 27, 2015, 12:57 PM).

266. Id.; see also Mike McIntire, Conservative Nonprofit Acts as a Stealth Business Lobbyist, N.Y. TiMES (Apr. 21, 2012), https://www.nytimes.com/2012/04/22/us/alec-a-tax-exempt-group-mixeslegislators-and-lobbyists.html?pagewanted=all [https://perma.cc/P4AK-55ZL (dark archive)] (noting that some corporations donate over $\$ 100,000$ a year to the organization and corporate representatives sit at ALEC conferences with legislators on various task forces that address topics like telecom, health care, and product liability). 
LGBTQ rights in fact donate substantial sums to legislation in direct opposition to these causes. ${ }^{267}$

Moreover, it is not just the money spent, but also other questionable lobbying tactics that gives cause for concern. Alexander Hertel-Fernandez has detected a recurring pattern of employers actively mobilizing their workers to lobby for causes (business, political, or otherwise) that the employers, but not necessarily the employees, care about: workers are expected to support their employers not only with logistical help but also by providing a crucial input in persuading public opinion. ${ }^{268}$ Indeed, Hertel-Fernandez shows how employer mobilization can actually shape congressional work, as legislative staffers find it helpful "especially when it involves having employees express their support for or opposition to particular policy proposals." ${ }^{269}$ In a similar vein, corporations sometimes attempt to advance their self-interest by creating, or funneling money to, faux grassroots organizations that purport to be acting in pursuit of social causes. This lobbying is known as "astroturf activism." ${ }^{270}$ Corporations ranging from Big Oil to Big Tobacco to Big Pharma have engaged in astroturfing to shape public perception-for example, creating fake citizens groups or scientific bodies to publish articles or ostensible "research" that undermines evidence on climate change or health science. ${ }^{271}$ Businesses also hire teams of individuals who pose as disinterested members of the public (often creating multiple profiles), but who in reality promote corporate causes. ${ }^{272}$ For

267. See Jacob S. Hacker \& Paul Pierson, Foreword to FREED ET AL., supra note 263, at 2. Corporate funds were used to "seat candidates who have gerrymandered legislative districts and put in place ballot restrictions harming black people; opposed action to address climate change; opposed LGBTQ rights; attacked the Affordable Care Act, including during the pandemic; and sought to restrain women's reproductive rights." Strine, Restoration, supra note 12, at $422 \mathrm{n} .86$; see also Leo E. Strine, Fiduciary Blind Spot: The Failure of Institutional Investors To Prevent the Illegitimate Use of Working Americans' Savings for Corporate Political Spending, 97 WASH. U. L. REV. 1007, 1027-29 (2020) (documenting the difficulties of tracking such spending given that it is funneled through dark committees and thus neither investors nor the public can know how much is given by whom and to whom).

268. See HERTEL-FERNANDEZ, supra note 263, at 118 (noting that employers are increasingly recruiting their workers-sometimes in coercive ways-to help them run their causes).

269. Id. at 164 (describing survey work showing that $49 \%$ of congressional staffers find it "'extremely or very' useful" when employees "offer assistance with legislation"); see also id. at 162-72 (examining how employer mobilization can impact congressional decision-making).

270. See John Braithwaite \& PETER DRAHOS, Global Business REgUlation 489 (2000) (providing examples of astroturf NGOs, including Consumers for World Trade, a pro-GATT industry coalition; Citizens for Sensible Control of Acid Rain, a coal and electricity industry coalition; and the National Wetlands Coalition, a coalition of U.S. oil companies and real estate developers). See generally Melissa J. Durkee, Astroturf Activism, 69 STAN. L. REV. 201 (2017) (discussing the ways in which businesses imitate grassroot organizations).

271. See George Monbiot, The Denial Industry, GuARDIAN (Sept. 19, 2006, 10:45 AM), https://www.theguardian.com/environment/2006/sep/19/ethicalliving.g2?INTCMP=SRCH [https:// perma.cc/3BAR-JFC8].

272. They accomplish this using "personal management software" which automatically generates the appearance of a real profile, including "pre-aged" accounts that make it appear as thought the 
example, the SEC recently "received ghost-written letters in support of the proposed regulations [regarding proxy advisors] that were fraudulently represented as letters from ordinary investors." 273

While lobbying usually occurs opaquely, some large companies do it out in the open. Facebook, Amazon, Apple, and Google all spend substantial sums on lobbying - and, for the most part, have increased their lobbying expenditures substantially over the past decade, mostly on antitrust issues. ${ }^{274}$

Empirical work shows that these lobbying efforts yield large financial rewards for corporations. ${ }^{275}$ However, instead of sharing wealth with weaker constituencies, corporations lobby to reduce certain costs, including their labor and tax bills, and to fight legislation that could otherwise expose them to liability. ${ }^{276}$

"person" has been posting and retweeting for months. George Monbiot, The Need To Protect the Internet from 'Astroturfing' Grows Ever More Urgent, GUARDIAN (Feb. 23, 2011, 7:01 AM), https://www.theguardian.com/environment/georgemonbiot/2011/feb/23/need-to-protect-internetfrom-astroturfing [https://perma.cc/F5WW-DWJB].

273. See Jonathan Macey, Opinion, Behind the SEC's War on Freedom of Speech, BLOOMBERG QUINT (Mar. 2, 2020, 4:30 PM), https://www.bloomberg.com/amp/opinion/articles/2020-03-02/secs-new-rules-undermine-shareholder-rights [https://perma.cc/2QDK-38MH] ("The SEC apparently relied on these fake letters in measuring public support for its proposed regulations ....").

274. See Ryan Tracy, Tech Firms Ramp Up Lobbying as Antitrust Scrutiny Grows, WALL ST. J. (Oct. 28, 2019, 5:30 AM), https://www.wsj.com/articles/tech-firms-ramp-up-lobbying-as-antitrust-scrutinygrows-11572255000 [https://perma.cc/JYW7-8A9X]. Amazon has substantially increased its lobbying expenditures in the wake of increased antitrust scrutiny from Congress, spending $\$ 4.38$ million in lobbying in the second quarter of 2020-9\% more than they spent the previous year. Skylar Woodhouse \& Ben Brody, Amazon Sets New Lobbying Record as Tech Antitrust Scrutiny Grows, BLOOMBERG TECH. (July 21, 2020), https://www.bloomberg.com/news/articles/2020-07-21/amazon-sets-new-lobbyingrecord-as-tech-antitrust-scrutiny-grows [https://perma.cc/NJC2-7YXK]. Facebook spent $\$ 4.83$ million in the second quarter, an almost $18 \%$ increase from the previous year. Id.

275. See Michael J. Cooper, Huseying Gulen \& Alexi V. Ovtchinnikov, Corporate Political Contributions and Stock Returns, 65 J. FIN. 687, 715-18 (2010); Hui Chen, David Parsley \& Ya-Wen Yang, Corporate Lobbying and Firm Performance, 42 J. BUS. FIN. \& ACCT. 444, 445-61 (2015); Robert S. Chirinko \& Daniel J. Wilson, Can Lower Tax Rates Be Bought? Business Rent-Seeking and Tax Competition Among U.S. States, 63 NAT'L TAX J. 967, 968-86 (2010); Hill et al., supra note 254, at 931. Financial economists found "an association between corporate political participation and outcomes such as equity returns, shareholder wealth, and state tax policy." Janet Meade \& Shihong Li, Strategic Corporate Tax Lobbying, 37 J. AM. TAX'N ASS'N, 23, 26 (2015).

276. See Arbitration Rule Repeal Is Payback to Big Banks, PUB. Citizen (July 20, 2017), https://www.citizen.org/news/arbitration-rule-repeal-is-payback-to-big-banks/ [https://perma. cc/6BJX-NE3C (staff-uploaded archive)] (explaining that the financial industry gave more than $\$ 100$ million to Republicans who fought to repeal the CFPB's mandatory arbitration rule); Magali Delmas, Jinghui Lim \& Nicholas Nairn-Birch, Corporate Environmental Performance and Lobbying, 2 ACAD. MGMT. DisCOVERIES 175, 175 (2017) (explaining that between 2006 and 2009 firms spent over a billion dollars lobbying on climate related issues); Aaron Gregg \& Douglas MacMillan, Nation's Biggest Business Lobby Is Behind Republicans' Push To Shield Employers from Coronavirus Liability, WASH. POST (Aug. 25, 2020, 6:20 AM), https://www.washingtonpost.com/business/2020/08/25/americas-biggestbusiness-lobby-is-behind-republicans-push-shield-employers-coronavirus-liability [https://perma.cc/ MT2X-KSKZ (dark archive)]. There is also substantial empirical evidence showing that corporations and industry groups spend heavily on efforts to reduce their tax bill or retain taxation benefits. See, e.g., 
Corporate efforts to avoid liability were on sharp display recently. The U.S. Chamber of Commerce pushed hard to shield employers from coronavirus liability, including drafting legislation that would have protected companies from any pandemic-related liability. ${ }^{277}$ Corporations have been devoting significant resources to lobby against important parts of the Biden administration's budget bill, including provisions that would raise taxes on wealthy individuals and corporations and provisions that would expand Medicare to cover vision, hearing, and dental treatment. ${ }^{278}$ More than 4,000 lobbyists and ten major industries have spent almost $\$ 700$ million in lobbying this year so far. ${ }^{279}$ Many large corporations, including Apple, Amazon, Microsoft, and Disney-who professed commitments on the environmenthave lobbied to combat provisions of the budget bill proposing taxes and fees to curb climate change. ${ }^{280}$

All told, corporations spend substantial sums each year to preserve and increase their share of resources and their influence on matters in which they perceive their interests and their employees' interests as adversarial.

\section{Corporate Efforts To Thwart Worker Rights and Engagement}

Aside from spending substantial sums to keep and enhance their influence in the lawmaking process, corporations also take concrete steps to avoid ceding any power or resources to workers. Below, we provide examples that highlight how corporations have hindered unionization efforts, prevented workers from enforcing their rights via mandatory arbitration clauses, and thwarted the rights of gig workers.

\section{a. Preventing Unionization}

Corporations deploy a variety of tactics to discourage worker unionization. While some tactics are legal (for example, hiring consulting firms to discourage

Meade \& Li, supra note 275, at 24 (showing that firms increase their lobbying expenses in years where tax benefits are set to expire, an example of defensive lobbying deployed to "retain a tax benefit it currently enjoys"); see also Brian K. Richter, Krislert Samphantharak \& Jeffrey F. Timmons, Lobbying and Taxes, 53 AM. J. POL. SCI. 893, 893 (2009). Empirical evidence also shows that corporations lobby more in order to retain or gain resources. See Timothy M. La Pira, Herschel F. Thomas \& Frank R. Baumgartner, The Two Worlds of Lobbying: Washington Lobbyists in the Core and on the Periphery, 3 INT. GRPS. \& ADVOC. 219, 237 (2014).

277. See Gregg \& MacMillan, supra note 276.

278. Luke Broadwater, With Biden's Agenda in Balance, Lobbying Kicks into High Gear, N.Y. TiMES (Oct. 4, 2021), https://www.nytimes.com/2021/10/04/us/politics/biden-lobbying-congress. html [https://perma.cc/99BF-Y4VW (dark archive)].

279. Oliver Milman, Apple and Disney Among Companies Backing Groups Against US Climate Bill, GUARDIAN (Oct 1, 2021, 2:00 PM), https://www.theguardian.com/us-news/2021/oct/01/appleamazon-microsoft-disney-lobby-groups-climate-bill-analysis [https://perma.cc/TZ2M-YPRF].

280. Id.; see also Edward Luce, Joe Biden's Real Opponents Are Special Interests, FIN. TIMES (Oct. 21, 2021), https:/www.ft.com/content/2818267d-d864-4df2-8702-917f8468f1c5 [https://perma.cc/KKT99DUV (staff-uploaded, dark archive)]. 
unionization) or use the law (for example, challenging coordination efforts by gig workers on antitrust grounds), ${ }^{281}$ some other tactics are illegal (for example, firing or otherwise retaliating against employees who attempt to unionize). ${ }^{282}$

The anti-unionization efforts of some high-profile companies, such as Walmart, Google, Amazon, Trader Joe's, and Starbucks are well known; ${ }^{283}$ in fact, data show that union-busting is not isolated but an extremely widespread phenomenon. According to a report based on NLRB records, U.S. employers were charged with violating federal law in $41.5 \%$ of all union election campaigns that took place between 2016 and 2017. ${ }^{284}$ According to earlier data, employers threatened to close plants in $57 \%$ of elections, discharged workers in $34 \%$ of

281. See supra note 169 and accompanying text.

282. For a recent example of the use of illegal tactics, see Zoe Schiffer, Instacart Is Firing Every Employee Who Voted To Unionize, VERGE (Jan. 21, 2021, 2:15 PM), https://www.theverge.com/2021/1/ 21/22242676/instacart-firing-every-union-employee-coronavirus-pandemic [https://perma.cc/69LVWLJV].

283. See Karen Weise, Amazon Illegally Fired Activist Workers, Labor Board Finds, N.Y. TIMES (June 15, 2021), https://www.nytimes.com/2021/04/05/technology/amazon-nlrb-activist-workers.html [https://perma.cc/Y5D8-U47S (dark archive)] (reporting that the National Labor Relations Board found that Amazon illegally retaliated against two critics); David Streitfeld, Amazon's Clashes with Labor: Days of Conflict and Control, N.Y. TIMES (June 15, 2021), https://www.nytimes.com/2021/04/05/ technology/amazon-control-bathroom-breaks.html [https://perma.cc/R9ZJ-HZBE (dark archive)] (reporting that, among other things, Amazon workers were not paid for overtime, resorted to urinating in bottles because they were denied bathroom breaks, were constantly surveilled, and that Amazon engaged in union busting); Susan Berfield, How Walmart Keeps an Eye on Its Massive Workforce, BLOOMBERG BUSINESSWEEK (Nov. 24, 2015), https://www.bloomberg.com/features/2015-walmartunion-surveillance/ [https://perma.cc/FW6E-YU8A] (reporting that Walmart hired Lockheed Martin to track organized labor supporters in the workforce); David Yaffe-Bellany, Labor Fights Collides with the Pandemic at Trader Joe's, N.Y. Times (Nov. 19, 2020), https://www.nytimes.com/2020/04/02/ business/trader-joes-unionization-coronavirus.html [https://perma.cc/G37N-FAE3 (dark archive)]; Noam Scheiber \& Daisuke Wakabayashi, Google Hires Firm Known for Anti-Union Efforts, N.Y. TIMES (Nov. 20, 2019), https://www.nytimes.com/2019/11/20/technology/Google-union-consultant.html [https://perma.cc/7NML-LLWD (dark archive)]; Dani Romero, Starbucks Asks 3 Northeast Stores To Vote 'No' on Unionizing as Critical Labor Vote Looms, YAHOO! FIN. (Nov. 2, 2021), https://finance.yahoo. $\mathrm{com} /$ news/starbucks-asks-3-northeast-stores-to-vote-no-on-unionizing-as-critical-labor-vote-looms230223057.html [https://perma.cc/4WYV-W7EG]; see also HERTEL-FERNANDEZ, supra note 263, at 56-57 (describing the Walmart and Lockheed surveillance efforts and mentioning that the Public Affairs Council recommends in its best practices for employer mobilization that managers "track" their employee advocates). Amazon workers in Alabama recently voted to decline to join a union, but Amazon engaged in heavy anti-union activity leading up to the vote, including airing anti-union ads and placing signs in bathrooms, with some workers reporting feeling that they were being harassed. Jay Greene, Amazon's Anti-Union Blitz Stalks Alabama Workers Everywhere, Even the Bathroom, WASH. POST (Feb. 2, 2021, 6:00 AM), https://www.washingtonpost.com/technology/2021/02/02/amazon-unionwarehouse-workers/ [https://perma.cc/53PR-ZLVH (dark archive)]; Annie Palmer, Amazon Wins Enough Votes To Beat Union Effort in Alabama, CNBC (Apr. 9, 2021, 2:10 PM), https://www.cnbc.com/ 2021/04/09/amazon-union-vote-live-updates-as-counting-resumes-in-alabama.html [https://perma.cc/ 87V9-A7W7].

284. CELine MCNicholas, MARgARET POYdoCK, JUlia WOLFE, BEN ZiPPERER, GORDON LAFER \& LOLA LOUSTAUNAU, ECON. POL'Y INST., UNLAWFUL: U.S. EMPLOYERS ARE CHARGED WITH VIOLATING FEDERAL LAW IN 41.5\% OF ALL UNION ELECTIONS 2 (2019), https://files. epi.org/pdf/179315.pdf [https://perma.cc/B328-PYLQ]. 
elections, and threatened to cut wages and benefits in $47 \%$ of elections. ${ }^{285}$ Workers were forced to attend anti-union one-on-one sessions with a supervisor at least weekly in two-thirds of elections and, in $63 \%$ of elections, employers interrogated workers in one-on-one meetings about who they and other employees supported, and threatened employees in $54 \%$ of such sessions. ${ }^{286} \mathrm{In}$ one-fifth of these elections, employers were charged with illegally firing workers. ${ }^{287}$ In nearly a third of elections, employers were charged with "illegally coercing, threatening, or retaliating against workers" for supporting a union. ${ }^{288}$ In addition, employers spend almost $\$ 340$ million per year on union consultants designed to help them prevent employees from unionizing. ${ }^{289}$ Further, corporate intermediaries such as the Chamber of Commerce ${ }^{290}$ and ALEC ${ }^{291}$ have spent substantial sums seeking to diminish the power of unions, as well as drafting and backing the "right-to-work" laws that are in effect in 27 states. ${ }^{292}$

Some large corporations, like Google, have seen intense unionization battles: although 400 Google engineers finally succeeded in unionizing in January of $2021,{ }^{293}$ the company had employed a number of tactics, including hiring a consulting firm known for its anti-union efforts, to fight this unionization. ${ }^{294}$ Additionally, Google fired Timmit Gebru, a Black woman who published research showing racial bias in facial recognition technology, and who

285. Kate Bronfenbrenner, ECON. POl'y Inst., No Holds Barred: THE INTENSIFICATION OF EMPLOYER OPPOSITION TO ORGANIZING 2 (2009), https://files.epi.org/page/ -/pdf/bp235.pdf [https://perma.cc/NPY2-HXT8].

286. Id.

287. MCNICHOLAS ET AL., supra note 284, at 2.

288. Id.

289. Id.

290. See Gordon Lafer, What's Wrong with 'Right-To-Work': Chamber's Numbers Don't Add Up, ECON. POL'Y INST. (Mar. 1, 2011), https://www.epi.org/publication/pm174/ [https://perma.cc/LYQ79CEA].

291. Prokop, supra note 265.

292. Right-To-Work Resources, NAT'L CONF. ST. LEGISLATURES, https://www.ncsl.org/research/ labor-and-employment/right-to-work-laws-and-bills.aspx [https://perma.cc/GGC9-DLJH].

293. Kate Conger, Hundreds of Google Employees Unionize, Culminating Years of Activism, N.Y. TIMES (Jan. 4, 2021), https://www.nytimes.com/2021/01/04/technology/google-employees-union. html [https://perma.cc/5QTM-L2TA (dark archive)] [hereinafter Conger, Hundreds of Google Employees Unionize]; see also Bobby Allyn, Google Workers Speak Out About Why They Formed a Union: 'To Protect Ourselves,' NPR (Jan. 8 2021, 2:10 PM), https://www.npr.org/2021/01/08/954710407/at-googlehundreds-of-workers-formed-a-labor-union-why-to-protect-ourselves [https://perma.cc/DU5E-UY78 (staff-uploaded archive)].

294. Google Fired Employees for Union Activity, Says US Agency, BBC NEWS (Dec. 3, 2020, 10:01 PM), https://www.bbc.com/news/technology-55173063 [https://perma.cc/N5LS-XATN] [hereinafter Google Fired Employees] (reporting on NLRB complaint alleging that Google unlawfully monitored and questioned employees regarding their union activity and that Google employees were fired for efforts to unionize); Scheiber \& Wakabayashi, supra note 283. 
spoke out against how the company treats women and people of color. ${ }^{295}$ The engineers' decision to unionize is partly attributed to anger over Gebru's firing. ${ }^{296}$

Indeed, while illegal, firing a worker for unionizing is "commonplace" in the United States: "[a]n employer determined to get rid of a union activist knows that all that awaits, after years of litigation if the employer persists in appeals, is a reinstatement order the worker is likely to decline and a modest back-pay award." ${ }^{297}$ Also, as noted above, ${ }^{298}$ employers deploy oppressive tactics to deter workers from joining unions, including "mandatory captive-audience meetings and mandatory, pressure-filled, one-on-one meetings between individual workers and their supervisors, with the latter coached by consultants on how to present self-organization as risky to employees' interests." ${ }^{299}$ In addition, employers often "predict" closures or downsizing in the event of unionization; while not legally categorized as a threat, such statements obviously have a chilling effect. ${ }^{300}$ Indeed, even during the COVID-19 pandemic, a number of companies have fired employees who have attempted to start unions. ${ }^{301}$ Some employers used the pandemic as an excuse to delay a union election, ${ }^{302}$ and others expressed open opposition to unions. ${ }^{303}$

\section{b. Preventing Workers from Enforcing Their Rights via Mandatory} Arbitration Clauses

Corporations also routinely reduce employee power by forcing workers to sign mandatory arbitration clauses. Mandatory arbitration clauses thwart workers' ability to enforce their rights-under such clauses, employees cannot

295. Bobby Allyn, Google Employees Call Black Scientist's Ouster 'Unprecedented Research Censorship,' NPR, https://www.npr.org/2020/12/03/942417780/google-employees-say-scientists-ouster -was-unprecedented-research-censorship [https:/perma.cc/U5RA-5AVY] (Dec. 3, 2020, 11:36 PM).

296. Id.

297. LANCE A. COMPA, Hum. RTs. WATCH, UnFAIR AdVANTAGE: WorkERS' FreEDOM OF ASSOCIATION IN THE UNITED STATES UNDER INTERNATIONAL HUMAN RIGHTS STANDARDS 25 (2000), https://ecommons.cornell.edu/bitstream/handle/1813/75158/Compa164_Unfair_advantage.pdf ?sequence=1\&isAllowed $=y$ [https://perma.cc/82JS-Y3Z8].

298. See supra note 169 and accompanying text.

299. COMPA, supra note 297, at 26.

300. Id. at 29; see also HERTEL-FERNANDEZ, supra note 263, at 77-81 ("[E]ven though most of the time employers do not end up closing plants, stores, or factories after successful union elections, the mere mention of those threats is often enough to sway workers into opposing the unions, especially when made in concert with other threats of wage or benefits cuts.").

301. See Schiffer, supra note 282; Jessica Silver-Greenberg \& Rachel Abrams, Fired in a Pandemic 'Because We Tried To Start a Union,' Workers Say, N.Y. Times (Mar. 8, 2021), https://www.nytimes.com/2020/04/28/business/coronavirus-unions-layoffs.html [https://perma.cc/JR P9-KQ44 (dark archive)].

302. See Silver-Greenberg \& Abrams, supra note 301.

303. See id. (mentioning that, at Trader Joe's, the CEO circulated a letter opposing unions and calling efforts to unionize "a distraction," and a worker reported having been fired after creating "a Facebook page to discuss working conditions"). 
bring their claims to court, but instead are confined to a mandatory disputeresolution process selected by the company. ${ }^{304}$ Data show that this process overwhelmingly favors employers, ${ }^{305}$ and few workers even bother attempting to find relief in arbitration. According to one study, assuming that employees covered by mandatory arbitration clauses were as "willing and able" to litigate as employees not covered by mandatory arbitration clauses, there would have been between 320,000 and 727,000 employment claims in arbitration filed in 2016. Instead, only 5,126 claims were filed that year. ${ }^{306}$ That is, the filings in arbitration represent less than $2 \%$ of the employment claims one would expect to be filed. ${ }^{307}$

The majority of the workforce, then, is de facto barred from access to the courts. A 2018 study showed that sixty-million workers-representing 55\% of the workforce-were bound by mandatory arbitration clauses-a number that has more than doubled over the past two decades. ${ }^{308}$ In 1992, just $2 \%$ of workers were subject to mandatory arbitration, but that number had grown to a quarter of the workforce by the early 2000 s. ${ }^{309}$ Workers who are subject to mandatory arbitration may be barred from litigating claims arising out of Title VII of the Civil Rights Act, the Americans with Disabilities Act, the Family and Medical Leave Act, and the Fair Labor Standards Act. ${ }^{310}$ Nearly a third of these mandatory arbitration clauses include class action waivers, preventing almost a quarter of the workforce (23.1\%, which represents 24.7 million workers) from litigating their employment rights in class action claims. ${ }^{311}$ Marginalized

304. See Alexander J.S. Colvin, The Growing Use of Mandatory Arbitration, ECON. POL'Y INST. (Apr. 6, 2018), https://www.epi.org/publication/the-growing-use-of-mandatory-arbitrationaccess-to-the-courts-is-now-barred-for-more-than-60-million-american-workers/ [https://perma.cc/H 739-XT7Z]. The widespread use of arbitration clauses began in earnest in 1999, when the legal teams of companies such as Bank of America, Chase, Citigroup, Discover, Toyota, and General Electric together developed a strategy to "use the fine print of contracts to stop class actions." Daisuke Wakabayashi \& Jessica Silver-Greenberg, Facebook To Drop Forced Arbitration in Harassment Cases, N.Y. TiMES (Nov. 9, 2018), https://www.nytimes.com/2018/11/09/technology/facebook-arbitrationharassment.html [https://perma.cc/VNS9-2CQZ (dark archive)].

305. See Alexander J.S. Colvin \& Mark D. Gough, Individual Employment Rights Arbitration in the United States: Actors and Outcomes, 68 INDUS. \& LAB. REL. REV. 1019, 1019 (2015) ("[E]mployers that use the same arbitrator on multiple occasions win more often and have lower damages awarded against them than do employers appearing before an arbitrator for the first time.").

306. Estlund, Black Hole, supra note 86, at 696.

307. Id. Empirical studies have also provided evidence that employee claims have declined since AT\&T Mobility LLC v. Concepcion, 563 U.S. 333 (2011), and that few employees bother pursuing lowvalue cases. See, e.g., David Horton \& Andrea Cann Chandrasekher, Employment Arbitration After the Revolution, 65 DEPAUL L. REV. 457, 496 (2016).

308. Colvin, supra note 304.

309. Large companies are more likely than smaller ones to deploy mandatory arbitration; among companies with 1,000 or more employees, $65.1 \%$ subject their workers to mandatory arbitration. Id. Among nonunion employees overall, $56.2 \%$ are subject to mandatory arbitration. Id.

310. $I d$.

311. $I d$. 
workers are more likely to be impacted, as mandatory arbitration is disproportionately deployed in low-wage workplaces and in industries in which Black workers and women are overrepresented. ${ }^{312}$

The Supreme Court has blessed the widespread use of arbitration clauses and has prevented state efforts to restrict arbitration clauses, holding them to be preempted by the Federal Arbitration Act. ${ }^{313}$ One might argue that employers should not be faulted for deploying arbitration clauses when the law so clearly permits (and even endorses) their use. This is precisely why direct regulation is necessary to ensure that workers have enforcement rights. Under stakeholderism, corporations can simply argue that arbitration clauses barring worker actions benefit consumers, or, borrowing from Supreme Court jurisprudence, can laud arbitration clauses as promoting "choice."

\section{c. Thwarting the Rights of Gig Workers}

As discussed in Part II, corporations have deployed tremendous resources to fight legislative efforts aimed at requiring that gig workers be classified as employees. Uber, Lyft, and other gig economy companies, including delivery start-ups, spent over $\$ 200$ million to convince Californians to support Prop 22, which ultimately deprived gig workers of the standard protections and benefits to which employees are entitled. ${ }^{314}$ Even before that campaign, Uber and Lyft flatly refused to comply with the law requiring them to classify their drivers as employees and threatened that they would shut down operations in the state if they were forced to reclassify their drivers. ${ }^{315}$

Further, corporations rely on the fissured nature of employment to avoid providing workers with the protections and benefits that they must provide to employees. ${ }^{316}$ As Human Rights Watch has found, if independent contractors or subcontractors attempt to unionize, prime contractors often simply cancel their contracts. ${ }^{317}$ The result "is widespread denial of workers' freedom of

312. Id.

313. See, e.g., AT\&T Mobility LLC v. Concepcion, 563 U.S. 333, 339, 343 (2011); Am. Express Co. v. Italian Colors Rest., 570 U.S. 228, 233 (2013). For a detailed description of Supreme Court jurisprudence, see David Noll, Regulating Arbitration, 105 CALIF. L. REV. 985, 993-1002 (2017). Noll emphasizes that, in order to be effective, any regulation seeking to restore litigation rights to consumers or other weaker constituents must include a robust private enforcement mechanism. See id. at 1033-37, 1044, 1054.

314. Conger, Remain Contractors, supra note 242 (mentioning that Prop 22 was the most expensive ballot measure in California's history, with companies outspending opponents of Prop 22 by ten to one).

315. Id.

316. See WEIL, FISSURED WORKPLACE, supra note 86; see also supra notes 232-35 and accompanying text.

317. COMPA, supra note 297 , at 38 . 
association under international norms, often affecting the most vulnerable workers in the labor force." 318

\section{B. The Dubious Advantages of Stakeholderism}

According to a recurring assertion, stakeholderism has the advantage of offering a more feasible alternative to direct regulatory measures such as those described in Part II. ${ }^{319}$ After all, stakeholderism is now championed by the likes of the Business Roundtable, on the one hand, and progressive politicians, on the other; ${ }^{320}$ it would thus seem to have greater chances of becoming actual law.

However, feasibility alone is not a positive per se. To be clear on what a stakeholder approach can achieve, it is vital to evaluate whether it could actually act as a substitute for the reforms we survey in Part II by providing equivalent protections to workers. The overarching question is whether a stakeholderist proposal would be capable of shifting power and resources to workers. In Section III.B.1, we establish that, in order to be protective of weaker constituencies such as workers, the proposal would need to be mandatory, enforceable, and specific. Current proposals do not seem to track any such features. We then ask whether stakeholderism could at least have any positive impact in advancing the position of workers by creating an environment conducive to regulation. We answer the question in the negative and note that stakeholderist corporate governance did not play a role in any of the recent worker advancement; in fact, we argue that stakeholderism is more likely to serve as a roadblock to regulation than to pave the way for it.

\section{A Feasible Substitute for Direct Regulation?}

In Part II, we identified policy initiatives outside of corporate law and governance that are capable of shifting power and resources to workers. To determine if stakeholderism would be a feasible substitute to such reforms, we need to establish whether it can be as effective in giving workers power and resources. Stakeholder proponents sensitive to the plight of weaker constituents acknowledge that optional regimes lacking enforceable, litigable rights are going to be ineffective. ${ }^{321}$ Otherwise, the only advantage of stakeholderism would be

318. Id.

319. See Strine, Restoration, supra note 12, at 434; Mayer, Shareholderism Versus Stakeholderism, supra note 43 , at 9 .

320. See supra note 3 and accompanying text.

321. Strine, Restoration, supra note 12, at 426. To be sure, critics of stakeholderism see its inherent inability to offer enforceable protection as one of its main flaws. See, e.g., Ann M. Lipton, What We Talk About When We Talk About Shareholder Primacy, 69 CASE W. L. REV. 863, 865 (2019); Stephen M. Bainbridge, A Critique of Senator Elizabeth Warren's “Accountable Capitalism Act" (Part 3): She Hasn't Thought Through the Enforcement Mechanism, PROFESSORBAINBRIDGE.COM (Aug. 15, 2018), https://www.professorbainbridge.com/professorbainbridgecom/2018/08/a-critique-of-senator- 
its feasibility relative to antitrust or labor initiatives - a trait that alone cannot give any indication of the desirability of the policy. We argue that, in order to meaningfully improve workers' positions, a stakeholderist proposal must be mandatory, enforceable, and specific. Anything short of that would make the substitute ineffective.

First, any regime that merely allows managers and directors to consider the needs of various constituencies does very little, if anything, to protect any particular constituency; instead, it gives managers and directors more leverage to look after their own interests. ${ }^{322}$ Moreover, a regime that is not mandatory would not apply equally to all workers, because it would benefit only those lucky enough to work for corporations that voluntarily take stakeholderism seriously. ${ }^{323}$ Remaining workers would not experience change. Note that this can be a very vast group, which includes those employed by corporations that voluntarily disregard stakeholderism, but also those who work for employers not organized as corporations (from LLCs to sole proprietorships to nonprofits) ${ }^{324}$ or in corporations of a smaller size that typically face less pressure to adopt best

elizabeth-warrens-accountable-capitalism-act-part-3-she-hasnt-thought-through-.html [https://perma. cc/9WW7-PATG].

322. This is exactly what happened with the failed experiment of constituency statutes. See Lucian A. Bebchuk, Kobi Kastiel \& Roberto Tallarita, For Whom Corporate Leaders Bargain, 93 S. CAL. L. REV. (forthcoming 2021) (manuscript at 3), https://papers.ssrn.com/sol3/papers.cfm?abstract_id=3677155 [https://perma.cc/S67T-UBC8]; Julian Velasco, The Fundamental Rights of the Shareholder, 40 U.C. DAVIS L. REV. 407, 463-64 (2006) (explaining that the impact of these statutes has been "rather insignificant" because they are optional and lack any enforcement rights to other stakeholders); Ronald J. Gilson, Leo Strine's Third Way: Responding to Agency Capitalism, 33 J. CORP. L. 47, 52 (2007) (explaining why constituency and antitakeover statutes do not protect workers).

323. For the argument that under stakeholderism as conceived by the BRT, addressing the weaker constituencies' needs or concerns will entirely depend on managerial discretion, see Enriques, Same Old, supra note 38; Pistor, Against Shareholders, supra note 38; Summers, supra note 36. For an account describing how stakeholderist efforts might differ depending on the competitiveness of the market in which the firm operates, see Mark J. Roe, Corporate Purpose and Corporate Competition 12 (Eur. Corp. Governance Inst., Working Paper No. 601, 2021) [hereinafter Roe, Corporate Purpose], https://papers.ssrn.com/sol3/papers.cfm?abstract_id=3817788 [https://perma.cc/ YG24-9SWW] (explaining that, in competitive markets, "if the ESG or CSR does not reward the firm-in either greater productivity, better branding, or otherwise-the firm will face pressure or friction with its suppliers," and noting that while firms may sacrifice profit to pursue ESG/CSR in the short term, "doing so in the long run with be difficult or impossible," while monopolist firms, by contrast, can comply with ESG/CSR and continue to be profitable). Indeed, the advantages of working for certain employers and the disadvantages of working for others are well-documented determinants of inequality. See supra note 63 and accompanying text.

324. For the remark that businesses could even consider changing organizational form to avoid stakeholderism, see Griffith, supra note 39, at 9. For the argument that weaker constituencies might be subject to abuse from entities other than corporations, see Gatti \& Ondersma, supra note 7, at 60-61 (citing the minimum wage campaign at Harvard in the early 2000s, Kickstarter's opposition to unionization, and the role of large private universities in gentrification and duress in real estate markets). 
governance practices. ${ }^{325}$ Besides, a nonmandatory regime would present a typical holdout problem, whereby firms that truly opt into a stakeholder approach may expect to be punished with returns lower than those who have opted out $^{326}$ (and opt-in firms may even decide to reverse course, especially if pressed by investors). ${ }^{327}$ Such a collective action problem might push corporations to not credibly and consistently practice what they preach. ${ }^{328}$

Enforceable rights are also critical to any regime that purports to improve the lot of workers. Absent litigable rights and effective sanctions, there would

325. See generally Kobi Kastiel \& Yaron Nili, The Corporate Governance Gap, 131 YALE L.J. (forthcoming 2021), https://papers.ssrn.com/sol3/papers.cfm?abstract_id=3824857 [https://perma.cc/ EQT6-G8YL] (noting that smaller and less scrutinized corporations tend to not follow their larger peers in adopting arrangements that are generally considered to foster better governance).

326. Cf. Leo E. Strine, Jr., The Delaware Way: How We Do Corporate Law and Some of the New Challenges We (and Europe) Face, 30 DEL. J. CORP. L. 673, 691-92 (2005) ("Without appropriate regulation by the citizenry's duly elected representatives, the least ethical of businessmen will trash the environment, exploit workers, and steal from investors-thereby creating inexorable pressures for others to follow suit in order to survive.").

327. John Armour, Luca Enriques \& Thom Wetzel, Corporate Carbon Reduction Pledges: Beyond Greenwashing, UNIV. OXFORD FAC. L. (July 2, 2021), https://www.law.ox.ac.uk/business-law$\mathrm{blog} / \mathrm{blog} / 2021 / 07 / \mathrm{corporate}-\mathrm{carbon}$-reduction-pledges-beyond-greenwashing [https://perma.cc/92Y4 -A6K5] ("Yet, share ownership changes over time, which render their control unstable. In particular, if a gap opens between the profit-maximising strategy at the firm level and the firm's stated environmental commitments, it may be vulnerable to attention from shareholder activists who seek to reverse the commitments in order to increase firm-level profits."); see also Goshen \& Levit, supra note 54, at 9 (arguing that labor decline has been caused by 'concentration of shareholders' market power over management of numerous entities, each separately pursuing its own economic interest").

328. Channeling Mancur Olson's teachings on collective action, a corporation will decide to pursue the common good for stakeholders only if its individual benefit is greater than the costs borne by pursuing the common good. See MANCUR OlsON, THE LOGIC OF COLLECTIVE ACTION 33 (rev. ed. 1971) (explaining that "if at any level of purchase of the collective good, the gain to the group exceeds the total cost by more than it exceeds the gain to any individual, then there is a presumption that the collective good will be provided, for then the gain to the individual exceeds the total cost of providing the collective good to the group"). But if enough corporations decide to hold out and keep pursuing shareholder value maximization (because they prefer shareholder value or are afraid that other firms will hold out too), those who are pursuing the common good for stakeholders will be at a disadvantage in capital markets as they will bear the costs for pursuing the common good while the corporations that hold out will not. See id. at 44 (explaining that a common good will not be provided when "no single individual's contribution makes a perceptible difference to the group as a whole, or [to] the burden or benefit of any single member of the group"). As a result, only a few firms will truly pursue stakeholderist goals. See Roe, Corporate Purpose, supra note 323, at 18-23 (arguing that only firms operating in noncompetitive settings can afford to pursue a stakeholderist agenda, while those under the pressure of competitive markets might take a more cautious approach). This dynamic has started to make victims overseas, as it contributed to the Danone CEO losing his job. See Vivienne Walt, $A$ Top CEO Was Ousted After Making His Company More Environmentally Conscious. Now He's Speaking Out, TIME (Nov. 21, 2021， 7:00 AM), https://time.com/6121684/emmanuel-faber-danone-interview/ [https://perma.cc/X2RR-VQ6Y] (noting that, while on the one hand the Danone CEO got praise from environmentalists after turning Danone into the French equivalent of an American benefit corporation and creating a carbon adjusted earnings per share indicator, on the other hand "the company's shares lagged behind peers like Nestlé and Unilever during the pandemic, as sales of some key Danone products like Evian water plummeted."). 
be no sufficient incentives for corporations to comply with their duties ${ }^{329}$ and no deterrent for failure to comply. ${ }^{330}$ Note incidentally that under the shareholder primacy norm itself, at least from a fiduciary duty standpoint, directors enjoy ample discretion because of the protections from exculpatory provisions, $\mathrm{D} \& \mathrm{O}$ insurance, and, especially, the business judgment rule. ${ }^{331} \mathrm{In}$ this regard, as we provocatively stated elsewhere, "the only way to make a stakeholder reform truly effective would be to abandon the business judgment rule." 332

Even assuming that mandatory and enforceable stakeholder reform is realistically achievable, it would still be necessary to identify specifics about what the board would be expected to do. Consider that, under a stakeholderist regime, directors are asked to consider the issues of a wide variety of constituencies, from shareholders to workers, consumers, creditors, the environment, and so forth. No matter how mandatory, a stakeholderist regime, by its own design, affords managers tremendous leeway and, without specificity, any action can be justified as purportedly benefiting one constituency or another-this is what critics of stakeholderism call the "too many masters"

329. Jonathan R. Macey, The Central Role of Myth in Corporate Law 22 (Eur. Corp. Governance Inst., Law Working Paper No. 519/2020, 2020) [hereinafter Macey, Myth in Corporate Law], https://papers.ssrn.com/sol3/papers.cfm?abstract_id=3435676 [https://perma.cc/2YYQ-GH8J] ("Officers and directors respond to incentives, and therefore are highly subject to powerful market constraints that lead them to maximize shareholder value even though the law does not.").

330. See, e.g., Strine, Restoration, supra note 12, at 426; Velasco, supra note 322, at 463-64; Gilson, supra note 322, at 52. Although Colin Mayer suggests that a stakeholderist statement of corporate purpose is enough to make management's accountability "laser sharp," he does not offer specifics as to what trade-offs and judgments would best serve weaker constituents, or how this sharp accountability would come into being. See Mayer, Shareholderism Versus Stakeholderism, supra note 43, at 10.

331. See STEPHEN M. BAINBRIDGE, CORPORATE LAW 223 n.5 (2d ed. 2009) (recognizing that a board too sensitive or insensitive to requests by weaker constituencies will be protected by the business judgment rule for non-Revlon decisions); Macey, Myth in Corporate Law, supra note 329, at 27-28, 27 n.95 (citing Bernard S. Sharfman, Shareholder Wealth Maximization and Its Implementation Under Corporate Law, 66 FLA. L. REV. 389, 393-99 (2014)). Some authors emphasize the unimportance of fiduciary duties as a policy tool, see Fried, supra note 37; Gatti \& Ondersma, supra note 7, at 21-22; Jonathan Povilonis, The Use and Misuse of Fiduciary Duties: Why Corporate Fiduciary Duties Aren't Worth Fighting For, WM. \& MARY L. REV. (forthcoming 2021) (manuscript at 4), https://papers.ssrn.com/ sol3/papers.cfm?abstract_id=3752756 [https://perma.cc/6CVU-T3FF], because directors' allegiance to shareholders comes from elsewhere. See MARK J. ROE, POLITICAL DETERMINANTS OF CORPORATE GOVERnANCE: POliticAl CONTEXT, CORPORATE IMPACT 45-46 (2003) (mentioning, among other things, compensation, takeovers, securities markets); Fried, supra note 37; Bebchuk \& Tallarita, Illusory Promise, supra note 39, at 155, 176 (noting that corporate compensation structures, as well as labor and control markets, provide managers and directors with significant incentives to look out for shareholders' interests, but no incentives to look out for stakeholder interests); Rock, For Whom, supra note 39 , at 376, 392 (noting that shareholders elect boards and set limits to their discretion).

332. Gatti \& Ondersma, supra note 7, at 21 (adding that the "question is ... whether [abandoning the business judgment rule] would ever be a realistic scenario, given that historically the judiciary does not want to step into the shoes of directors and managers in deciding how to run the business"). 
problem. ${ }^{333}$ For example, directors may argue against worker protections because they harm consumers, or may propose downsizing as necessary to reduce the corporation's carbon footprint. Further, workers themselves have heterogenous interests. ${ }^{334}$

Therefore, a stakeholderist proposal aiming to be a feasible substitute for reforms directly protecting workers must also identify specifically what the board must do. Such a proposal seems prima facie at odds with the very structure of directors' fiduciary duties, which tend to be open-ended and operate ex post like a standard, ${ }^{335}$ rather than as a specific and ex ante brightline rule. While this is precisely why we are skeptical of an expansion of fiduciary duties in the first place, we nevertheless can try, arguendo, to identify what specifically managers and directors could be expected to do under a stakeholderist regime. That is no easy task: it is in fact unclear whether and how the goals policymakers seek to achieve via antitrust or labor reform could be privately reached through corporate governance changes calling for or contemplating unilateral actions by the corporation itself. For instance, what would be the specific duties around, say, an upcoming acquisition expected to tighten labor markets? What about unionization requests? Would such a mandate make sufficiently clear that hiring union-busting consultants would violate this duty? In other words, hypothesizing a revision of director duties in such a fashion would per se require a formidable stretch of imagination-even then, it is almost impossible to expect a sufficient level of specificity.

Lacking specific duties and enforcement rights that directly benefit workers, these proposals are of limited utility. Once we acknowledge that specificity comes at a premium for weaker constituencies, it then becomes illogical to seek to achieve those goals via an expansion of fiduciary duties, rather than direct regulation. Unsurprisingly, the optional and unenforceable nature of stakeholderism is precisely what appeals to managerialists, who "will not even use the word 'shall' to describe a director's duty to other stakeholders, much less indulge the notion of giving stakeholders enforcement or other

333. See Stephen M. Bainbridge, Director Primacy: The Means and Ends of Corporate Governance, 97 NW. U. L. REV. 547, 550 (2003); Griffith, supra note 39, at 6. For additional context, see also Gatti \& Ondersma, supra note 7, at 12-15.

334. See, e.g., Katharina Pistor, Codetermination: A Sociopolitical Model with Governance Externalities, in EMPlOyEES AND CORPORATE GOVERNANCE 163, 182-83 (Margaret Blair \& Mark J. Roe eds., 1999) (describing the difficult balance the employee bench of a company needs to strike to give sufficient voice and weight in the supervisory board to heterogeneous groups such as members of the company's workers' council, white collar workers, union representatives not employed by the company, and members of the workers' councils of subsidiaries).

335. See generally Edward B. Rock, Saints and Sinners: How Does Delaware Corporate Law Work?, 44 UCLA L. REV. 1009 (1997) (analyzing the inner mechanics of how Delaware cases are adjudicated and how fiduciary duties work in practice). 
rights." ${ }^{336}$ As noted earlier, far from aiding in a shift that offers greater power and resources to workers or other weaker constituents, corporations have long resisted any measure that would entail significant changes of the status quo, especially measures requiring corporations to divert or repurpose resources or cede prerogatives and power. ${ }^{337}$ Thus, if any of these proposals did include mandatory, enforceable, specific obligations, we expect they would face substantial resistance from corporate executives and their advocates. Conversely, if a stakeholderist reform did not include mandatory, enforceable, and specific provisions, not only would it be a bad substitute for more meaningful reform, but it may also harm workers because managers and directors would have a wider panoply of potential justifications for any action or inaction. ${ }^{338}$

\section{A Better Environment To Advance Workers' Interests?}

If stakeholderism is not a viable substitute for effective reforms, can it still be expected to provide some incremental improvements, or at least promote a

336. Strine, Restoration, supra note 12 , at 427 . Indeed, corporations and their defenders explicitly acknowledge that a key reason to promote stakeholderism is to defend against direct regulation. See infra notes 370-71 and accompanying text. That is why even shareholder advocates may be willing to get on board with such a regime (on the basis that it is better from a long-term value standpoint): "[S]tockholders have little to fear from a 'may' regime, but stakeholders have nothing to gain from it." Strine, Restoration, supra note 12, at 427; Bebchuk et al., supra note 322, at 50 (providing evidence that top corporate managers did not use constituency statutes to protect employees or communities of operation, but instead used the leverage to benefit shareholders and themselves). To be sure, some stakeholderist proposals do include mandatory duties. Proposals by Elizabeth Warren and Leo Strine would impose a mandatory public benefit corporation ("PBC") regime, at least for some of the largest and wealthiest institutions. Strine, Restoration, supra note 12, at 431-32. The PBC model would not only permit, but would impose a "mandatory, normative duty" on the board to "respect all stakeholders" and "balance the interests of various stakeholders." Id. at 428; Accountable Capitalism Act, S. 3348, 115th Cong. $\S 5$ (2018). The question is what happens if they do not wish to live up to this duty. Even though the model is a mandatory one, corporations will choose which stakeholders to prioritize and how, and we should be prepared for corporations to simply identify a constituent who benefits from their desired course of action. For example, companies may claim that downsizing benefits shareholders, creditors, and consumers, or that raising worker pay and benefits will result in higher prices and thus harm consumers, or that certain cuts are necessary for emissions reductions. And how will these various constituencies enforce their interests, if at all? PBC statutes "create the potential for a suit to enforce the board's duty to stakeholders, even if not by means of monetary liability." Strine, Restoration, supra note 12, at 428 . But without any monetary liability, directors and managers have no incentive to worry about compliance ex ante, because failure to abide by their duty will never cost more than abiding if all they have to do is change their behavior in the future. Kishanthi Parella proposes an alternative mandatory regime in which corporations must consider stakeholder interests in negotiating contracts that may physically harm stakeholders. Kishanthi Parella, Contractual Stakeholderism, 102 B.U. L. REV. (forthcoming 2022) (manuscript at 1), https://papers.ssrn.com/sol3/papers.cfm?abstract_ $\mathrm{id}=3821887$ [https://perma.cc/P6C2-B656]. Again, however, the obligation is to consider stakeholder interests, so the risk that managers will proffer a balancing-of-interests justification remains; additionally, it remains unclear whether and how harmed parties would be able to obtain any redress.

337. See supra Section III.A.2.

338. See Gatti \& Ondersma, supra note 7, at 64-67. 
setting more conducive to advancing workers' positions? Optimistically, a stakeholder approach could change corporate culture and reshape directors' priorities. In this view, when no longer pressed to cater exclusively to shareholders, directors would look after weaker constituencies as well. ${ }^{339}$ In such a changed environment, corporations, constituents, and policymakers would find it easier to dialogue and cooperatively work toward reform. At least incrementally, we would start to see the policy needle moving towards a more mature form of stakeholder capitalism, in a direction more favorable to the workforce. ${ }^{340}$ Strine summarizes and agrees with this view:

[I]f corporate law itself, and particularly the power dynamics within it, would change, we can get corporations themselves to behave more responsibly. Not only would this involve them treating their stakeholders and society better, it would also specifically involve trying to limit the extent to which corporations use their influence to prevent the political process from putting in place effective external regulations. That is, in order to revitalize external regulation, advocates of a fairer society rationally became convinced that internal corporate governance reform was required. ${ }^{341}$

In his view, "without addressing corporate power and how it is used," it is unlikely that this external regulation will be adopted. ${ }^{342}$

339. Strine, Restoration, supra note 12, at 401 ("By evolutionary means, which build on current techniques of corporate law, and that restore the regulatory framework within which corporate power used to be exercised, we can build a sounder basis for sustainable prosperity and greater social unity, because we will create incentives for our economy to more fairly share its gains with the workers whose hard work and innovation is primarily responsible for creating them."). However, Strine does not explain what these incentives might look like, thus it remains unclear how corporate governance can play a meaningful role in ensuring that corporations share gains with workers. See id.

340. In part because of investor pressure, the current momentum indicates that corporations are more sensitive than ever to issues such as climate, human capital, and public interest issues in general. See, e.g., Madison Condon, Externalities and the Common Owner, 95 WASH. L. REV. 1, 6 (2020) (arguing that climate activism by some in the institutional investor industry is explainable as a way to tame systemic risk); John C. Coffee, Jr., ESG, Common Ownership, and Systematic Risk: How They Intersect 29 (Eur. Corp. Governance Inst., Working Paper No. 541, 2020), https://papers.ssrn.com/sol3/papers. cfm?abstract_id=3678197 [https://perma.cc/DQ9M-7UXP] (arguing that large index funds have been pushing for mandating environmental, social, and governance ("ESG") disclosures to help reduce systemic risk); Stavros Gadinis \& Amelia Miazad, Corporate Law and Social Risk, 73 VAND. L. REV. 1401, 1413 (2020) (arguing that ESG's real function is to manage risk and that recent efforts have been prompted by pressures from asset managers); Roberto Tallarita, Stockholder Politics, 73 HASTINGS L.J. (forthcoming 2021) (manuscript at 14-21), https://papers.ssrn.com/sol3/papers.cfm?abstract_id= 3798101 [https://perma.cc/SRH7-H4F5] (describing the rise of public interest shareholder proposals in the 2010s and concluding that they mitigate agency costs on public interest issues); Matteo Tonello, 2021 Proxy Season Preview and Shareholder Voting Trends (2017-2020), HARV. L. SCH. F. ON CORP. GOVERNANCE (Feb. 11, 2021), https://corpgov.law.harvard.edu/2021/02/11/2021-proxy-seasonpreview-and-shareholder-voting-trends-2017-2020/ [https://perma.cc/LRJ4-DZL5] (documenting emboldened efforts on climate and human capital during the 2020 proxy season).

341. Strine, Restoration, supra note 12 , at 423.

342. Id. at 433 . 
In an ideal world, a corporation that embraces stakeholderism would indeed be expected to bring less friction in industrial relations and a more welcoming stance on unions and other labor market institutions protecting workers. If stakeholderism could offer that, it could actually lead to success.

However, there is little indication that this is happening or is the direction stakeholderism is moving toward. Indeed, unlike Strine, the corporatist adherents to stakeholderism and the investor community that embrace stakeholderism likely do not want any substantive change in labor market institutions. The former would likely oppose change because stronger unions would be considered a disruptive counterbalance to managerial power and perks; ${ }^{343}$ the latter would also see such change as an increase in systemic risk as corporate profits would be expected to be reduced across the board as a result of higher labor costs. ${ }^{344}$ Thus, even if managers and directors are required to consider the interests of their employees, they are unlikely to shift meaningful power to them by allowing-much less encouraging-unions. For example, Amazon could argue that it considered its employees' interests because it increased wages, even while at the same time taking measures to deter employee unionization.

Recent empirical studies confirm our skepticism. Aneesh Raghunandan and Shiva Rajgopal found no evidence that signatories of the BRT Statement have engaged in practices fostering stakeholders' interest: compared to their peer firms in the relevant industry, "signatories of the BRT statement have higher rates of environmental and labor-related compliance violations (and pay more in compliance penalties as a result)." ${ }^{345}$ This study also found "initial evidence that BRT signatories do not appear to have changed their ways subsequent to signing the Statement although we admittedly cannot verify whether BRT signatories will improve their future track records regarding stakeholder treatment in the longer term." ${ }^{346}$ Similarly, a study by Lucian Bebchuk and Roberto Tallarita focuses on the corporate documents of the 130 signatories to the BRT Statement in order to assess the likelihood of companies following through on their professed commitments to stakeholders. ${ }^{347}$ The

343. See supra Section II.A.2.

344. For the assertion that labor costs represent systemic risk, see, for example, Robert Hockett, Open Labor Market Operations, 62 CHALLENGE 113, 117 (2019). Indeed, thus far investor initiatives on human capital management tend to gravitate towards issues such as diversity, but not actual labor empowerment. See infra note 374; cf. Goshen \& Levit, supra note 54, at 10 (noting that common ownership by mutual and index funds has resulted in weaker labor markets and higher profits).

345. Raghunandan \& Rajgopal, supra note 15, at 2 (noting also that signatories to the BRT Statements have, relative to their peers, higher carbon emissions, rely more on government subsidies, and are more likely to disagree with proxy recommendations on shareholder proposals).

346. Id. at 27.

347. See generally Bebchuk \& Tallarita, Will Corporations Deliver Value, supra note 15 (finding that (i) the corporate documents have not added any language improving the status of stakeholders and that most of them retain in their guidelines a commitment to shareholder primacy, (ii) most do not mention 
study finds that the bylaws, proxy statements, and other corporate documents continue to reflect a commitment to shareholder primacy and do not bolster the position of stakeholders. ${ }^{348}$ Business leaders may be concerned about certain societal shifts as a result of rising inequality (whether out of genuine civic concern or concern for the long-term bottom line), but in any event they have not shown appetite to institute any changes that would require them to give up any real power or resources.

Besides, as Dorothy Lund and Elizabeth Pollman explain, shareholder maximization principles are not enshrined only in corporate governance rules, but also-and arguably more inextricably - in and through influential investors, investor associations, industry associations, proxy advisors, stock exchanges and indexes, ratings agencies, and corporate culture (including professional schools, media, and the political arena). ${ }^{349}$ For this reason, "legal discretion is not enough to change corporate behavior if the other components of the corporate governance machine remain intact." 350 Given the entrenched, interlocking

stakeholders in their discussion of corporate purpose, (iii) corporations have not changed their treatment of shareholder proposals during the 2020-2021 proxy season, (iv) corporate bylaws are still shareholder-centric, (v) proxy statements do not reflect any change in the treatment of stakeholders, and (vi) executive compensation continues to be aligned with shareholder value). Martin Lipton has criticized this study on the grounds that reflecting stakeholderist commitments in corporate documents would have been practically irrelevant. Martin Lipton, More Myths from Lucian Bebchuk, HARV. L. SCH. F. ON CORP. GOVERNANCE (Aug. 24, 2021), https://corpgov.law.harvard.edu/2021/08/24/moremyths-from-lucian-bebchuk/ [https://perma.cc/Q982-DQJL]. He has also offered evidence of stakeholderist achievements at certain corporations. See id. (citing JPMorgan as having "committed billions to minority communities" and having "pledged to broaden its hiring case," Sephora's "effort to combat racial bias in customer's retail experience," GM electing a majority-female board of directors, and Nike creating the "lowest-carbon shoe ever"). Of course, Lipton's examples cannot be mistaken for proof that stakeholder capitalism has been delivering. Rather, they show that some businesses are engaging in pro-stakeholder practices they feel comfortable with. Only time will tell whether these are isolated cases or form part of a broader trend. Regardless, initiatives at certain corporations are of no use for workers employed elsewhere. For the reasons explained in Section III.B.1, the advancement of weaker constituencies cannot be attained without mandatory, enforceable, and specific floors.

348. Bebchuk \& Tallarita, Will Corporations Deliver Value, supra note 15, at 53.

349. Lund \& Pollman, supra note 22, at 18-32.

350. Id. at 49. Lund and Pollman explain why subordinating profit to stakeholder interests is an unlikely outcome given the existing landscape:

Routine profit-sacrificing is ... unlikely to increase the company's stock price, and therefore, these actions could lead to a cascade of negative consequences for the management team. Most directly, the decision to put other groups ahead of shareholders could sacrifice management's own compensation, which has become increasingly tied to the company's financial performance as a result of pressure from the machine's market players. Perhaps even more importantly, the decision might attract negative attention from investors, especially if governance ratings agencies downgraded the company in the wake of the move. Other shareholders might instead use their governance rights to show disapproval such as by voting against executive pay at the next annual meeting. Proxy advisors, too, would likely react unfavorably, directing their shareholder clients to vote against management. Investor advocacy groups would similarly protest any move that downgraded shareholder value. And if the company continued to make significant prosocial profit-sacrificing choices into the 
nature of institutions with an interest in maintaining the status quo, we believe that our political capital is much better spent pushing for concrete changes that directly allocate power to workers and are not subject to managerial circumvention or dilution. ${ }^{351}$

So, if stakeholderism is not likely to lead to such improvements, what is it good for exactly? Thus far we have not been able to identify specific stakeholderist proposals that might move us forward in a meaningful way. Hence, we see no benefit to adopting a stakeholderist approach generally.

Consider that none of the recent advances for workers are attributable to any stakeholderist propulsion stemming from managerial initiative but are rather the product of worker empowerment and pressure and other bottom-up pressures coming from the public and from environmental, social, and governance ("ESG")-type investors. ${ }^{352}$

For example, stakeholderism has not played any role in the worker victories relating to removing mandatory arbitration clauses: corporations implemented these changes in the face of tremendous pressure from their workers and the public, largely because such clauses were hindering sexual harassment claims in the wake of \#MeToo. ${ }^{353}$ Google changed its policy after 20,000 employees walked off the job in protest of its handling of sexual

future, it is likely that influential investors with concentrated investments in the company would do more, or activists would take positions to do so. For example, those investors could wage a proxy fight until management changed course or was replaced with individuals who were better aligned with shareholder interests.

Id. (footnotes omitted).

351. Aneil Kovvali argues that the choice between stakeholderism and shareholderism is a false dichotomy: internal regulation is an essential companion of direct regulatory efforts given the barriers to regulation. Aneil Kovvali, The Stark Choice Hypothesis for Corporate Reform ${ }^{*} 7$ (2021) (unpublished manuscript) (on file with author). Kovvali highlights certain internal corporate efforts to address issues relating to climate change and racial justice. Id. at ${ }^{*} 5-6$. But none of the cited efforts are attributable to any specific substantive corporate governance change. While we have no issues with bottom-up pressure for corporate governance changes, we dispute that legal changes to director fiduciary duties should be considered a necessary step to broader reform. In fact, for the reasons we discuss here, they would not be a good use of political capital.

352. For the argument that shareholders, not management, have been the driving force behind the recent achievements by stakeholder governance, see Cathy Hwang \& Yaron Nili, Shareholder-Driven Stakeholderism, U. CHI. L. REV. ONLINE (Apr. 15, 2020), https://lawreviewblog.uchicago.edu/2020/04/ 15/shareholder-driven-stakeholderism-hwang-nili/ [https://perma.cc/NRC7-M3HB].

353. See Jennifer S. Fan, Employees as Regulators: The New Private Ordering in High Technology Companies, 2019 UTAH L. REV. 973, 1008-14 (chronicling the concessions made by Big Tech companies after employees challenged existing social norms and also noting mandatory arbitration was abandoned for discrimination claims); see also Wakabayashi \& Silver-Greenberg, supra note 304; Jena McGregor, Google and Facebook Ended Forced Arbitration for Sexual Harassment Claims. Why More Companies Could Follow., WASH. POST (Nov. 12, 2018), https://www.washingtonpost.com/business/2018/11/12/googlefacebook-ended-forced-arbitration-sex-harassment-claims-why-more-companies-could-follow/ [https://perma.cc/4QD9-CFEA (dark archive)]. 
harassment claims. ${ }^{354}$ Facebook no longer forces employees to settle sexual harassment claims in private arbitration. ${ }^{355}$ Apple, meanwhile, has eliminated arbitration clauses from employment contracts altogether. ${ }^{356}$ All these changes came in response to worker and public pressure. ${ }^{357}$

Similarly, Google engineers succeeded in unionizing in January of 2021 after the company opposed unionization efforts for years. ${ }^{358}$ The process succeeded because workers organized in secret for more than a year. ${ }^{359} \mathrm{In}$ addition, corporations only began raising minimum wages after the Fight for $\$ 15$ movement was successful in rallying public opinion. ${ }^{360}$

It is clear, then, that to the extent that corporations have granted workers' rights and resources, they have not done so via, or in response to, any top-down change in corporate governance structure (actual or expected), but because of bottom-up pressures from workers themselves. Unsurprisingly, empirical evidence shows that companies respond to negative media coverage by strengthening their corporate social responsibility ("CSR") performance. ${ }^{361}$

Not only is there no evidence of any benefit to a general stakeholderist approach, but there are also substantial risks to adopting a generalized stakeholderist agenda-even if nominally a progressive one. The history of arbitration is instructive to see how agendas can be co-opted. ${ }^{362}$ In 1925, business and trade associations joined progressives in advocating for passage of the Federal Arbitration Act ("FAA"), which directed courts to uphold most arbitration agreements. ${ }^{363}$ The FAA, however, did not include specifics, nor

354. Wakabayashi \& Silver-Greenberg, supra note 304.

355. Id. (noting that Uber and Microsoft also changed their arbitration policies).

356. $I d$.

357. For a detailed discussion of the role of tech workers in pushing for corporate policy changes, see generally Anat Alon-Beck, Times They Are A-Changin': When Tech Employees Revolt, 80 MD. L. REV. 120 (2020), and Fan, supra note 353.

358. See Conger, Hundreds of Google Employees Unionize, supra note 293; see also Google Fired Employees, supra note 294 (reporting on an NLRB complaint alleging unlawful monitoring and questioning of employees respecting their union activity).

359. See Conger, Hundreds of Google Employees Unionize, supra note 293.

360. See Andrias, supra note 77 , at $47-53$.

361. Jingoo Kang \& Y. Han Kim, The Impact of Media on Corporate Social Responsibility 1 (Dec. 19, 2013) (unpublished manuscript), https://ssrn.com/abstract $=2287002$ [https://perma.cc/7L8VCMU9] ("Using textual analysis of one million news articles about the largest $100 \mathrm{firms}$ in the US in terms of [philanthropic contributions] over 2000-2010, we find that firms strengthen their CSR performance and spend more on [philanthropic contributions] when the public opinion about their CSR is more negative with intense media coverage.").

362. Initially, "the rise of arbitration was led by liberal reformers during the Progressive Era who hoped to ensure access to a less costly, more efficient, and fair alternative dispute resolution forum for those who struggled in court." Sarah Staszak, Privatizing Employment Law: The Expansion of Mandatory Arbitration in the Workplace, 34 STUD. AM. POL. DEV. 239, 240 (2020) (citing Amalia D. Kessler, Arbitration and Americanization: The Paternalism of Progressive Procedural Reform, 124 YALE L.J. 2940, 2973-80 (2015)).

363. Id. at 246 . 
assign an administrative agency to oversee arbitration, thus "in effect relying on industry to shape the contours of arbitration in practice." ${ }^{364}$ In the 1960s, supporters of arbitration included unions, businesses, the legal community, and Democrats in Congress. ${ }^{365}$ Given this diverse support, corporations and their advocates "were able to capitalize on consensus when converting these resources and malleable institutional tools to new ends." 366 Even later, as some bills enforcing a mandatory arbitration process first emerged in the 1980s and 1990s, it was generally understood that arbitration would be voluntary and that judicial review must be available. ${ }^{367}$ Again, however, these assumed restrictions were never codified, and, beginning in 1991, corporations began deploying arbitration as an intentional strategy to avoid liability, crafting the mandatory, unilateral provisions that dominate arbitration today. ${ }^{368}$ This was not an isolated occurrence-businesses regularly co-opt existing statutes against weaker constituencies when advantageous: consider, for instance, employers' use of antitrust laws to thwart unionization attempts by gig workers. ${ }^{369}$

The tale of mandatory arbitration is a cautionary one: even if wellintentioned, any institutional change that lacks specifics-and delegates development of specifics to corporations-risks being co-opted entirely. Embracing stakeholderism can be equally perilous: rather than throwing workers a life raft, the law may be providing corporations a tool with which they can tighten their millstones.

\section{CONCLUSION}

In this Article, we have shown structural shortcomings of stakeholder reforms in corporate governance while also identifying several reforms that are capable of shifting power and resources to workers. There is, notably, no stakeholderist proposal that would be as protective as direct regulation; in fact, current proposals lack mandatory, enforceable, and specific provisions to govern directors and managers. Worryingly, not only is there a lack of evidence that stakeholderism can advance the cause of workers, but we fear that such a

364. Id. at 241. Staszak uses the concept of "conversion" to describe the mechanism of the shift in arbitration from a progressive idea to its existing purpose. Id. at 240-42. By "conversion," she refers to a gradual shift in an institution or policy due to a shift in the "actors empowered to control its form and function." Id. at 241 (citing Jacob S. Hacker, Privatizing Risk Without Privatizing the Welfare State: The Hidden Politics of Social Policy Retrenchment in the United States, 98 AM. POL. SCI. REV. 243, 248 (2004)). At the time, the expectation was that arbitration would be used in commercial transactions, but the Court deferred widely to arbitration clauses, including in the employment context. Staszak, supra note 362 , at $246-48$.

365. Staszak, supra note 362 , at 241.

366. Id. The legal community's support for arbitration was grounded in concern for inequality as well as administrative pragmatism. $I d$. at 244 .

367. Id. at 242 .

368. Id.

369. See supra note 126 and accompanying text. 
stakeholderist regime would instead give corporations more fuel with which to pursue their typical agenda of defending against more direct regulation. Corporate advocates have openly stated that "corporations and investors should band together and resist legislation and regulation that may discourage longterm investment or that presumes that the long-term health of society is not aligned with the long-term interests of business." 370 They urge managers and directors to advance stakeholderism to preserve their own interests, seizing ESG principles for themselves, specifically to advance their very own "longterm strategic goals." ${ }^{371}$ Indeed, "ESG became a business opportunity." "372 The managerialists amongst stakeholderist proponents explicitly discuss the need to deploy stakeholderism in order to defend against regulatory reform. ${ }^{373}$ At the same time, even shareholder maximization proponents such as certain hedge funds have begun citing ESG goals as justifications for practices and policies that serve their personal interests. These developments suggest that stakeholderism is likely to end up being little more than a battered rope in the tug-of-war between managerialists and shareholder advocates.

To be sure, although we believe stakeholderism is detrimental, our criticism does not extend to the renewed interest in corporate law for weaker constituencies. In fact, we welcome such interest and believe it is vital to recalibrate the discourse on ways to improve capitalism. Similarly, we welcome existing bottom-up initiatives from workers and the investor community that use certain corporate governance tools such as shareholder resolutions to sensitize businesses, as such initiatives have been quite successful thus far on issues such as climate change and seem to promise decent outcomes also on the labor front as well. ${ }^{374}$ Our critique of stakeholderism does imply that we are

370. See Lipton, Corporate Governance, supra note 14.

371. Andrew R. Brownstiein, Steven A. Rosenblum \& Trevor S. Norwitz, The ESG/TSR Activist "Pincer Attack," HARV. L. SCH. F. ON CORP. GOVERNANCE (Jan. 26, 2021), https://corpgov.law. harvard.edu/2021/01/26/the-esg-tsr-activist-pincer-attack/ [https://perma.cc/UP4X-LE9Y]; see also Parella, supra note 336 (explaining that a "benefits" approach to stakeholderism will fall short because shareholder and stakeholder interests often conflict).

372. Lund \& Pollman, supra note 22, at 38.

373. See id. at 52. For the account that asset managers' interest in ESG is market-share driven, see generally Michal Barzuza, Quinn Curtis \& David H. Webber, Shareholder Value(s): Index Fund ESG Activism and the New Millennial Corporate Governance, 93 S. CAL. L. REV. 1243, 1250 (2020) ("To win the millennial generation, index funds have turned their attention not simply to share price-the conventional marker of shareholder value - but to the social issues that millennial investors care about: shareholder values.").

374. See supra notes 340,352 . The advancement made possible by ESG initiatives in the context of 14a-8 shareholder resolutions is more palpable with respect to environmental issues. See generally Tonello, supra note 340 (documenting emboldened efforts on climate, with four shareholder proposals that managed to receive majority support in 2020 (compared to none in 2019) and obtained commitments to: disclose details of climate lobbying activities (Chevron), report on plans to reduce the company's contribution to climate change (J.B. Hunt Transport Services), and publish assessments of business risks of petrochemical operations and of investments in areas prone to natural disasters (Phillips 66)). Yet, the needle also seems to be moving on some human capital management issues, 
against governance reforms to allow board representation for workers; this Article simply stipulates agnosticism on codetermination, because we believe such an issue deserves separate analysis. ${ }^{375}$

Our criticism here is of the proposed expansion of corporate purpose and thus the reach of director duties. Indeed, the discussion on whether director duties should be broadened has ended up cannibalizing discussions on far more consequential issues for the protection of weaker constituencies-that is, the actual protective measures that need to be implemented.

Therefore, while the stakeholderist debate has the indubitable merit of having revamped interest in deeper inquiries on the sustainability of modernday business firms, it is problematic to consider such intervention as the main conduit, or even as a necessary step, to more equitable outcomes for weaker constituencies. This is precisely because merely broadening the beneficiaries of fiduciary duties is not an effective way to address the issues of weaker constituencies. Embracing it as a corporate law reform would mean prioritizing an avenue at the expense of reforms that would more directly redress inequitable outcomes for such constituencies. Given that corporations exert substantial efforts, and spend substantial funds, to avoid ceding any power or resources to other constituencies, there also is a high chance that stakeholderism could prove to be a significant roadblock to the reforms that would ultimately benefit them.

especially on the diversity front. Bolstered by legislative initiatives in states such as California, investors are pressing corporations to treat diversity as a central aspect of corporate governance, not just with regards to board composition, but with an eye to the whole workforce. Id. (noting that shareholders passed four resolutions on issues, such as transparency relating to metrics of workforce diversity and inclusion, the adoption of employee arbitration policies, and health and safety matters).

375. For an extensive analysis on the merits of codetermination, compare Jens Dammann \& Horst Eidenmuller, Codetermination: A Poor Fit for U.S. Corporations, 2020 COLUM. BUS. L. REV. 870 (2020) (criticizing codetermination), with Grant M. Hayden \& Matthew T. Bodie, Codetermination in Theory and Practice, 73 FLA. L. REV. 321 (2021) (supporting codetermination) and GRANT H. HAYDEN \& MATTHEW T. BODIE, RECONSTRUCTING THE CORPORATION FROM SHAREHOLDER PRIMACY TO SHARED Governance (2021) (same) and Leo E. Strine, Jr., Aneil Kovvali \& Oluwatomi Williams, Lifting Labor's Voice: A Principled Path Toward Greater Worker Voice and Power Within American Corporate Governance, 105 MINN. L. REV. (forthcoming 2021), https://papers.ssrn.com/abstract=3792492 [https://perma.cc/LL64-5RN5] (same). Importantly, Strine, Kovvali and Williams note that, absent structural changes and external regulation, merely adding "isolated workers" as minority members to the board is not likely to be successful in shifting power to workers; instead, they argue that restoring bargaining rights (including avenues for sectoral bargaining) and establishing a minimum wage are necessary to give workers greater leverage. Id. The authors also recommend a stakeholder approach for large corporations and improved EESG disclosures. Id. While we agree that the minimum wage and greater union rights are key to restoring power to workers, we disagree that a stakeholder approach is likely to help shift the playing field; indeed, for the same reasons the authors are skeptical of giving employees voice absent greater structural changes, we believe expanding the role of managers and executives is too risky under the current landscape. See supra Section III.B.2. 
